

\section{Organizadora}

Dariane Cristina Catapan

\section{Conceitos aplicados \\ nas ciências da saúde}

Vol. 01

Latin American Publicações 2021 
2021 by Latin American Publicações Ltda.

Copyright (c) Latin American Publicações

Copyright do Texto @ 2021 Os Autores

Copyright da Edição @ 2021 Latin American Publicações

Editora Executiva: Barbara Luzia Sartor Bonfim Catapan

Diagramação: Lorena Fernandes Simoni

Edição de Arte: Os Autores

Revisão: Os autores

O conteúdo do livro e seus dados em sua forma, correção e confiabilidade são de responsabilidade exclusiva dos autores. Permitido o download da obra e o compartilhamento desde que sejam atribuídos créditos aos autores, mas sem a possibilidade de alterá-la de nenhuma forma ou utilizá-la para finscomerciais.

\section{Editora-chefe:}

Profa. Dra. Dariane Cristina Catapan

\section{Conselho Editorial:}

Profa. Msc. Adriana Karin Goelzer Leinig, Universidade Federal do Paraná, Brasil. Prof. Dr. Sérgio António Neves Lousada, Universidade da Madeira, Portugal.

Prof. Dr. Rahmi Deniz Özbay, Marmara University, Turquia.

Prof. Dr. Sema Yilmaz Genç, Kocaeli University, Turquia. 


\begin{tabular}{|l|}
\hline Dados Internacionais de Catalogação na Publicação (CIP) \\
\hline C357c Catapan, Dariane Cristina \\
Conceitos aplicados nas ciências da saúde / \\
Dariane Cristina Catapan. São José dos Pinhais: \\
Latin American Publicações, 2021. \\
116 p. \\
Formato: PDF \\
Requisitos de sistema: Adobe Acrobat \\
Reader Modo de acesso: World Wide \\
Web \\
Inclui: Bibliografia \\
ISBN: 978-65-992783-8-9 \\
DOI: 10.47174/lap2020.ed.0000084 \\
1. Ciências. 2.Saúde. \\
I. Catapan, Dariane Cristina. \\
Título.
\end{tabular}

Latin American Publicações

São José dos Pinhais - Paraná - Brasil www.latinamericanpublicacoes.com.br/ editora@latianamericanpublicacoes.com.br

\section{Ano 2021}




\section{APRESENTAÇÃO}

O livro "Conceitos aplicados nas ciências da saúde vol. 1", editado e publicado pela Latin American Publicações Ltda., reúne oito capítulos que tratam sobre temas de relevância no contexto das ciências da saúde.

Assim, os trabalhos deste livro abordam escuta psicológica e psicanalítica no contexto hospitalar frente à angústia da equipe de saúde.

O próximo trabalho analisa por meio da Logoterapia as relações de influência entre o sentido atribuído à vida, o suporte social e o bem estar, bem como verificar a influência da idade sobre essas fatores.

O próximo trabalho apresenta os elementos teóricos que sustentam a aprendizagem experiencial e sua utilização no desenvolvimento de competências genéricas com alunos de graduação de uma Universidade, com base nos quatro elementos básicos da aprendizagem: pensar, observar, fazer e sentir; formação de sensibilização e avaliação por competências. Apoia-se no papel do professorpsicólogo na sua função de facilitador do processo formativo.

Em seguida, o próximo trabalho tem como objetivo descrever a produção de macro modelos de baixo custo que facilitassema aprendizagem quanto à anatomia do pulmão e anatomopatologia da COVID-19.

Depois, o próximo trabalho trata de como está sendo o cuidado coletivo, dos trabalhadores de saúde que estão prestando à assistência direta e indireta a população. Assim este trabalho tem o objetivo verificar as repercussões da pandemia da COVID-19 na saúde mental, do trabalho e na física, dos profissionais de saúde.

O próximo trabalho apresenta alguns gráficos estatísticos, como histogramas, gráficos de barras e boxplots, da amostra total e suas respectivas subamostras quando divididos por óbitos e casos recuperados de COVID-19 em pacientes indígenas no Estado do Acre.

O penúltimo capítulo aborda as estratégias de cuidado em saúde realizadas pelas equipes de consultório de um centro social em parceria com a secretaria municipal de saúde durante a pandemia junto à população em situação de rua no Município de São Paulo na perspectiva da prevenção bem como do acompanhamento da saúde das pessoas em situação de rua com suspeita e confirmação de COVID-19.

E, por fim, o último trabalho teve como objetivo verificar por meio de uma revisão bibliográfica de que forma a obesidade pode ser um fator de risco para um mau prognóstico diante de pacientes acometidos pelo novo coronavírus.

Desta forma agradecemos todos os autores e autoras pelo esforço colocados em seus trabalhos e esperamos contribuir com a comunidade científica, no avanço do conhecimento científico.

Boa leitura a todos e todas!

Profa. Dra. Dariane Cristina Catapan 


\section{SUMÁRIO}

CAPÍTULO 01

EXISTE LUGAR PARA A ANGÚSTIA NO HOSPITAL? UM OLHAR SOBRE A EQUIPE DE SAÚDE

Marcella Corrêa Laboissière

Elisa Jeronimo Aires Leite

Mônica Schiller d'Escragnolle Taunay

DOI: 10.47174/lap2020.ed.0000085

CAPÍTULO 02

A INFLUÊNCIA DO SENTIDO DA VIDA SOBRE O BEM ESTAR

Lucia Helena Walendy de Freitas

DOI: 10.47174/lap2020.ed.0000086

CAPÍTULO 03 29

OUTDOOR TRAINING: APRENDIZAGEM EXPERIENCIAL, ITINERÁRIOS DE TREINAMENTO DE GRADUAÇÃO

Emilio Ricci

DOI: 10.47174/lap2020.ed.0000087

CAPÍTULO 04

CriaAnato: PRODUÇÃO DE MACRO MODELOS FOCANDO NA

ANATOMOPATOLOGIA DA COVID-19

Maria Luzinete Batista Barbosa

Vitória Calixto da Nóbrega

Maryana Marinho Barbosa Bastos

Francisco de Assis Justino de Lima

Rebeca Souza Uchoa Oliveira

Monique Danyelle Emiliano Batista Paiva

Ana Aline Lacet Zaccara

Anna Ferla Monteiro Silva

DOI: 10.47174/lap2020.ed.0000088

CAPÍTULO 05

REPERCUSSÕES DA PANDEMIA DA COVID-19 NOS PROFISSIONAIS DE

SAÚDE: COMO ESTÁ QUEM ESTÁ NA LINHA DE FRENTE?

Andressa Karine Schons

Andressa Fátima May

Claudia Teresinha Muller

Flávia Michelle Pereira Albuquerque

Edilson Freitas Rodrigues

Michele Silva Lachno

DOI: 10.47174/lap2020.ed.0000089

CAPÍTULO 06 
DESCRIPTIVE ANALYSIS IN THE COVID-19 DATABASE AFTER ONE YEAR OF THE PANDEMIC DISEASE IN INDIGENOUS PATIENTS FROM THE STATE OF ACRE

Adolfo Henrique dos Santos Fernandes

Felipe dos Santos Lopes

DOI: 10.47174/lap2020.ed.0000090

CAPÍTULO 07

ESTRATÉGIAS DE CUIDADO EM SAÚDE REALIZADAS PELAS EQUIPES DE CONSULTÓRIO NA RUA/BOMPAR/SMS. JUNTO À POPULAÇÃO EM SITUAÇÃO DE RUA DURANTE A PANDEMIA NO MUNICÍPIO DE SÃO PAULO

Marta Regina Marques Akiyama

Rhavana Pilz Canônico

Rodrigo Sette

Maria Cristina Barboza Kawakami

DOI: 10.47174/lap2020.ed.0000091

CAPÍTULO 08

OBESIDADE E COVID-19: DUAS EPIDEMIAS QUE, COMBINADAS, REPERCUTEM EM MAU PROGNÓSTICO DE PACIENTES

lluskhanney Gomes de Medeiros Nóbrega Miranda

Ingrid Rafaella Mauricio Silva Reis

Isadora Garcia Pires

Dr. Juscelino Kubitschek Bevenuto da Silva

DOI: 10.47174/lap2020.ed.0000092

SOBRE A ORGANIZADORA 


\section{CAPÍTULO 01}

\section{EXISTE LUGAR PARA A ANGÚSTIA NO HOSPITAL? UM OLHAR SOBRE A EQUIPE DE SAÚDE}

\section{Marcella Corrêa Laboissière}

Psicóloga. Psicanalista. Especialista em Psicologia Clínica pela PUC-RIO.

Especialista em Psicologia Médica e Saúde Mental pela Faculdade de Ciências Médicas do Hospital Universitário Pedro Ernesto - FCM/HUPE/UERJ. Mestre pelo Programa de Pós-graduação em Psicanálise da Universidade do Estado do Rio de Janeiro - UERJ. Doutoranda pelo Programa de Pós-graduação em Psicologia Clínica e Cultura da Universidade de Brasília - UnB/Bolsista do CNPQ.

E-mail:marcellacl@gmail.com

\section{Elisa Jeronimo Aires Leite}

Psicóloga. Especialista em Psicologia Médica e Saúde Mental pela Faculdade de Ciências Médicas do Hospital Universitário Pedro Ernesto - FCM/HUPE/UERJ.

Mestre em Temas de Psicologia pela Faculdade de Psicologia e Ciências da Educação da Universidade do Porto.

E-mail: elisaaires@yahoo.com.br

\section{Mônica Schiller d'Escragnolle Taunay}

Psicóloga do HUPE/UERJ. Psicanalista -Sociedade Brasileira de Psicanálise do Rio de Janeiro. Especialista em Psicologia Médica - FCM/UERJ. Mestre em Saúde Coletiva - IMS/UERJ.

E-mail: mtaunay@ig.com.br

RESUMO: Esta pesquisa parte da atividade prática de Interconsulta realizada nos anos de 2015 e 2016 no Hospital Universitário Pedro Ernesto, hospital-escola da Universidade do Estado do Rio de Janeiro - UERJ. A Interconsulta consiste em uma atividade que, a partir do pedido de parecer elaborado pela equipe, após apreender alguma questão de ordem subjetiva do paciente ou da família, demanda-se o acompanhamento do profissional da psicologia. Assim, recebemos a demanda para G.J, 75 anos, diagnosticado com Linfoma Cutâneo das Células T. No atendimento, entendemos forte angústia na equipe de saúde, o que sinalizava que o pedido de escuta não se restringia ao paciente que, no presente momento, encontrava-se fora de cuidados terapêuticos. O psicólogo dentro do hospital geral é o responsável pela escuta minuciosa de cada caso, criando espaço e abrindo possibilidades para que as falas do paciente, da família e da equipe surjam. Neste trabalho foi feito um recorte nessa tríade, dando ênfase à equipe. A abordagem da investigação caracteriza-se por salientar a escuta do profissional de saúde mental em uma equipe multiprofissional como diferencial no tratamento. Realizou-se uma pesquisa qualitativa, elegendo a observação e a escuta analítica da equipe de saúde. A oferta de tratamento da Psicologia Médica e o olhar singular da Psicanálise operam como contribuição para o contexto hospitalar e para o âmbito da saúde.

PALAVRAS-CHAVE: Angústia; Hospital geral; Equipe de saúde; Psicologia médica; Psicanálise. 


\begin{abstract}
This research is part of the practical activity of Interconsultation carried out in the years 2015 and 2016 at Hospital Universitário Pedro Ernesto, teaching hospital of the Rio de Janeiro State University - UERJ. Interconsultation consists of an activity that, following the request for a technical opinion by the team, after apprehending some subjective question from the patient or family, the psychology professional is required to be monitored. Thus, we received the demand for GJ, 75 years old, diagnosed with Cutaneous T-Cell Lymphoma. In the service, we noticed a strong anguish in the health team, which signalized that the listening request was not restricted to the patient who, at that moment, was itself out of therapeutic care. The psychologist inside the general hospital is responsible for listening carefully to each case, creating space and opening possibilities for the speeches of the patient, family and team to emerge. In this study, a cut was made in this triad, emphasizing in the team. The research approach is characterized by highlighting the listening of the mental health professional in a multidisciplinary team as a differential in the treatment. A qualitative research was carried out, choosing the observation and analytical listening of the health team. The medical Psychology treatment offer and the unique look of Psychoanalysis operate as a contribution to the hospital context and to the health field.
\end{abstract}

KEYWORDS: Anguisch; General hospital; Health team; Medical psychology; Psychoanalysis. 


\section{INTRODUÇÃO}

Esta pesquisa parte da atividade prática de Interconsulta realizada nos anos de 2015 e 2016 no Hospital Universitário Pedro Ernesto, hospital-escola da Universidade do Estado do Rio de Janeiro - UERJ. Naquela ocasião, trabalhamos como psicólogas especializandas do Curso de Pós-graduação em Psicologia Médica e Saúde Mental. A interconsulta consiste em uma atividade que, a partir da elaboração de pedido de parecer feito pela equipe, após apreender alguma questão de ordem subjetiva do paciente ou da família, recorre aos profissionais da psicologia. Nesse contexto, recebemos a demanda para atendimento de G.J, 75 anos, diagnosticado com Linfoma Cutâneo das Células T. No atendimento, percebemos forte angústia na equipe de saúde, o que sinalizava que o pedido de escuta não se restringia apenas ao paciente que, no presente momento, encontrava-se fora de cuidados terapêuticos. Dessa forma, ao receber uma demanda, o psicólogo deve estar atento não apenas ao paciente no leito, mas, também, estender sua escuta aos familiares e a equipe de saúde. O caso de G.J foi discutido e atendido sob supervisão de Staff responsável.

\section{OBJETIVO E MÉTODO}

O objetivo do presente trabalho foi a escuta psicológica e psicanalítica no contexto hospitalar frente à angústia da equipe de saúde. A escuta singular da equipe como prática do psicólogo no contexto hospitalar assume destaque, tendo como referencial teórico, a psicologia médica e a psicanálise. Partindo desses pressupostos teórico-conceitual e da escuta singular do um a um, o método utilizado foi a pesquisa qualitativa com a observação e a escuta analítica da equipe de saúde.

Sabemos, a partir de Sigmund Freud, o valor que o estudo de caso tem para o contexto clínico e hospitalar. No presente trabalho, o estudo de caso não faz referência apenas ao paciente, mas, também, aos membros da equipe de saúde que, visivelmente angustiados frente ao caso de G.J, sentiam-se mal a ponto de não conseguirem a atuação desejada.

A fim de melhor ilustrar nossas experiências no contexto citado, apresentaremos fragmentos do caso ao longo da discussão. 


\section{RESULTADOS}

O ambiente hospitalar traz vivências de situações traumáticas tanto para o paciente como para a família e o profissional de saúde. O profissional da psicologia atuante no hospital geral precisa permanecer atento à demanda da equipe que, em geral, refere-se ao sofrimento psíquico do paciente. No hospital isso é verificado na medida em que o paciente apresenta comportamentos que escapam à conduta médica, ou seja: choro excessivo, recusa no uso de medicação, negação diante do quadro clínico, entre outros. Contudo, o que verificamos no caso de G.J, para nossa surpresa, foram atuações na equipe responsável por atender o paciente. Assim, fica a pergunta: o que o psicólogo pode escutar frente a angustia da equipe? Há espaço para o sofrimento da equipe? Muniz e Chazan, psiquiatras estudiosos no assunto, relatam que "a Psicologia Médica tem como principal objetivo de estudo as relações humanas no contexto médico" (2009, p.49) direcionando que, neste contexto, trata-se das relações humanas e não apenas do sujeito à beira do leito causa de sofrimento.

Ao adentrarmos a enfermaria em uma primeira abordagem, percebemos algumas dificuldades da equipe, como: o manejo com relação ao caso, a falta de comunicação com os familiares do paciente e, principalmente, profissionais que constantemente se ausentavam da enfermaria para lamentar o prognóstico do caso. Nosso papel consistiu em sinalizar os profissionais em relação a possibilidade do surgimento da angústia frente à morte e, ainda, proporcionar um lugar de escuta. Freud (1916[1915]), no texto 'Sobre a transitoriedade', indica a proximidade do luto pela perda de algo ou alguém como um enigma, um daqueles fenômenos que por si só não seriam explicáveis, porém, sinaliza que é a partir dos efeitos causados naqueles que permanecem em vida que é possível rastrear algum ponto obscuro entre a conflitiva relação vida e morte. No caso de G.J apostamos na equipe, organismo vivo e causado pelo quadro clínico que se apresentava. O paciente, por si só, pouco se interessava pela psicologia.

No hospital, o adoecimento do corpo e a hospitalização funcionam como possíveis disparadores para o aparecimento da angústia. Acreditamos que a oferta do profissional da psicologia nesse contexto possa funcionar de forma que o sujeito, a equipe e a família viva as situações ao qual o ambiente hospitalar invoca como um convite ao trabalho diante do que é possível ser feito. Além disso, que estes autores 
possam criar recursos psíquicos para não sucumbirem diante de certos cenários que, por vezes, são arrasadores. O psicanalista Mohallen aponta que, "a criatividade do analista, na urgência, é fundamental É preciso criar para produzir, com os recursos possíveis em cada situação, um convite ao trabalho". (2003, p.29). Portanto, a criação no hospital surge como um potente instrumento de ressignificação para o profissional psi e, também, para aqueles que se encorajam a falar da sua própria angústia.

\section{DISCUSSÃO}

O paciente G.J, 75 anos, internado por Linfoma Cutâneo de Células T, permaneceu no hospital por aproximadamente um ano, entre altas e reinternações. $A$ cada retorno, uma nova enfermaria o acolhia e um novo pedido de parecer para a psicologia era enviado. $\mathrm{O}$ paciente sempre causou desconforto às equipes que $\mathrm{o}$ atendiam, o aspecto de sua pele e o mau cheiro, causava repulsa aos que se aproximavam. Em sua última internação, o caso agravou-se e as medicações já não aliviavam suas dores. A enfermagem estava desconfortável com seu cuidado e a equipe médica já dizia não ter mais o que fazer, pois não podiam aumentar as doses dos medicamentos. O paciente se encontrava em cuidados paliativos.

Ao longo de duas semanas permanecemos na enfermaria, seja para falar com os familiares ou com membros da equipe. A partir da escuta oferecida uma residente pôde dizer que, 'aquele senhor ali deitado se parece com meu pai, não consigo dar banho nele'. Freud (1929), em 'O mal estar na civilização', aponta o corpo como uma das fontes de mal estar inerente a todo e qualquer sujeito, afirma que, os ruídos produzidos pelo corpo, marcam a característica da transitoriedade. E era exatamente o que a estudante se lamentava. Em um segundo momento viemos a saber que o pai da residente estava internado em outro hospital com o diagnóstico de câncer.

Podemos perceber, então, que a resposta psicológica de um parecer médico está em localizar o ponto de partida da demanda, isto é, depurar o autor ou, os autores, da angústia. Será que a equipe tem lugar para lidar com suas próprias angústias? Com Mohallen vemos que, "O hospital é um lugar propicio a malentendidos, já que diante de muita angústia fica difícil discernir o dentro e o fora" (2003, p.29). 
Logo, por vezes, observamos que o profissional de saúde aponta como demanda $o$ atendimento do paciente sem, de fato, deparar-se com a sua própria angústia. Após esse período, o paciente veio a falecer. O alívio da equipe era visível.

\section{CONSIDERAÇÕES FINAIS}

Podemos dizer que a função do profissional da psicologia no hospital requer atenção ao paciente internado, à família e à equipe. Portanto, a oferta de tratamento da Psicologia Médica e o olhar singular da Psicanálise operam como contribuição para o contexto hospitalar e para o âmbito da saúde. A ação do profissional é de ser responsável por promover a assistência à Saúde Mental e o acesso da escuta diferenciada, viabilizando a abertura de novos olhares para o sujeito e sua história. Apostamos em algo que ultrapassa a abordagem organicista, visão privilegiada no ambiente hospitalar. O que escutamos diz respeito à dimensão subjetiva de cada um.

A partir da escuta ofertada, a proposta é tratar uma outra urgência: a urgência subjetiva. O desafio que se apresenta para nós profissionais da escuta ativa no hospital geral é decantar a demanda que se apresenta para, só assim, ofertar uma escuta diferenciada. O principal achado deste trabalho é a percepção do sofrimento por parte da equipe, como isso é levado em conta e, principalmente, qual o lugar para a angústia dos profissionais.

Desenvolver um trabalho multidisciplinar no hospital é também lidar com as diferenças de métodos e abordagens sobre o fenômeno do sofrimento humano, reservando ao profissional o lugar de respeitar os limites de cada campo e, então, trabalhar na interseção entre as práticas. 


\section{REFERÊNCIAS}

FREUD, S. (1916 [1915]). Sobre a transitoriedade. In: FREUD, S. Obras

Psicológicas Completas deSigmund Freud. Rio de Janeiro: IMAGO, vol. XIV, 1974.

FREUD, S. (1930[1929]). O mal estar na civilização. In: FREUD, S. Obras Psicológicas Completas deSigmund Freud. Rio de Janeiro: IMAGO, vol. XXI, 1974.

MOHALLEM, L. N. (2003). Psicanálise e hospital: Um tempo de criação. In:

Psicanálise e Hospital 3Tempo e Morte: Da urgência ao ato analítico. Minas Gerais: Revinter Ltda, 2003. 29p.

MUNIZ, J.R.; CHAZAN, L.F. Ensino de psicologia médica. In: Mello Filho, Julio de; Burd, Miriam \&Cols. Psicossomática hoje. 2.ed. Porto Alegre: ARTMED, 2009. 49p. 


\section{CAPÍTULO 02}

\section{A INFLUENCIA DO SENTIDO DA VIDA SOBRE O BEM ESTAR}

\section{Lucia Helena Walendy de Freitas}

Mestre em Psicologia da Saúde pela Universidade Metodista de São Paulo; Trabalha, em consultório próprio, na cidade de São Paulo, com desenvolvimento humano por meio de Psicologia Positiva, Terapia do Sentido, Terapia Sistêmica e Yogaterapia Integral.

E-mail: florescer.suporte@gmail.com

RESUMO: Este estudo teve por objetivo analisar as relações de influência entre o sentido atribuído à vida, o suporte social e o bem estar, bem como verificar a influência da idade sobre essas fatores. Participaram da pesquisa 205 trabalhadores entre 16 e 88 anos, 65,4\% sexo feminino. Os instrumentos de coleta de dados foram: Dimensão Existencial da Escala de Bem Estar Espiritual; Escalas de Bem Estar Psicológico; Bem Estar Subjetivo e de Percepção de Suporte Social e dados demográficos. As análises revelaram que com o avançar da idade, há uma tendência a aumentarem os níveis de significados positivos atribuídos à vida; o apoio social é maximizado quando favorece a emergência do Sentido; bem como confirma a Logoterapia quando afirma que o Sentido é a causa essencial do bem estar e felicidade.

PALAVRAS-CHAVE: Bem estar psicológico; Bem estar subjetivo; Apoio social; Sentido da vida.

ABSTRACT: This study aimed to analyze the relations of influence between the meaning attributed to life, social support and well-being as well as to evaluate the influence of age on these factors. 205 employees participated in the survey between 16 and 88 years, $65.4 \%$ female. The instruments for data collection were: existential dimensions of Spiritual Wellness Scale; Scales of psychological well-being; Subjective well-being and Perceived Social Support and demographics. The analysis revealed that, with increasing age, there is a trend of increasing levels of positive meaning to life; Social support is maximized when it favors the emergence of meaning in life; and confirm the Logotherapy which affirm that the meaning is a main causal factor of wellbeing and happiness.

KEYWORDS: Psychological well-being; Subjective well-being; Social support; Meaning of life. 


\section{INTRODUÇÃO}

Segundo a conceituação da Logoterapia, o ser humano é composto pela dimensão biológica, psicológica, social e espiritual. Nesse contexto, a dimensão biológica corresponde ao corpo físico; a dimensão psicológica é composta por processos mentais relacionados com o desejo de prazer, de poder, com a aprendizagem e o condicionamento; a dimensão social está relacionada à cultura, às instituições e aos relacionamentos; e a dimensão espiritual refere-se à capacidade de fazer escolhas (livre arbítrio e responsabilidade), de atribuir valor às coisas, de dar sentido à vida e às respectivas situações. Essa dimensão espiritual corresponde à dimensão de significados essenciais que surgem por meio da motivação humana inerente e primária para encontrar o sentido de sua existência - a Vontade de Sentido (Frankl, 2003; 2013; Rodrigues, 1991).

De acordo com Frankl $(2003 ; 2013)$ o desejo de significado está subjacente aos demais desejos, de modo que estrutura todas as motivações e situações em todos os momentos da vida humana. Dessa motivação primordial para encontrar sentido, surge uma rede básica de significados essenciais, uma visão de mundo que afirma a vida incondicionalmente e proporciona um sentido estruturante, que faz com que as pessoas, no dia a dia, encontrem orientação e forças para enfrentar a sua existência. Isto quer dizer que a motivação humana essencial pela busca do sentido estrutura e orienta todas aspirações, metas, reações emocionais, identidade e autoestima, satisfação, atitudes, comportamentos, etc. Nessa perspectiva portanto, todo estado de saúde ou de doença depende, em algum nível, do quanto o ser humano entra em contato com seu mundo espiritual de valores e de significados.

Considerando-se esses pressupostos, é possível supor que tanto os níveis de felicidade quanto os de saúde estejam relacionados aos níveis de sentido atribuído à vida.

Em psicologia, a felicidade é objeto de pesquisas sobre Bem Estar. Esse campo de pesquisa diz respeito aos processos objetivos e subjetivos que levam as pessoas a avaliarem o grau de felicidade em suas vidas. Os estudos sobre Bem Estar estão fundamentados em duas grandes perspectivas: a visão eudaimônica e a e a visão hedônica. 
A eudaimônica consiste da visão de que o bem estar e a felicidade estão relacionadas ao desenvolvimento de virtudes e ao autoaperfeiçoamento. A corrente hedônica está associada à visão de que o bem estar e a felicidade dependem de fatores que favoreçam o equilíbrio emocional e a satisfação com a vida. Entre os estudos desenvolvidos sob a ótica da visão eudaimônica destaca-se a pesquisa desenvolvida por Carol Ryff e colaboradores sobre o conceito de Bem Estar Psicológico e sob a ótica da hedônica destaca-se a pesquisa desenvolvida por Ed Diener e colaboradores sobre o conceito denominado de Bem Estar Subjetivo ou Bem Estar Emocional. Além dessas duas perspectivas de bem estar, destaca- se a pesquisa de Christopher Ellison sobre o conceito de Bem Estar Espiritual, que tem por objetivo focar os aspectos transcendentais relativos ao bem estar religioso e existencial (Keyes, C. L. M., Shmotkin, D. \& Ryff, C. D., 2002; Ellison, C. G.; Levin, J. S., 1998).

Essas três visões do bem estar - Psicológico, Subjetivo/Emocional e Espiritual compõem um corpo de estudo, que em parte, está associado a duas das quatro dimensões humanas definidas pela Logoterapia - as dimensões psicológica e a espiritual.

Outro aspecto importante a ser considerado nos níveis de saúde e de bem estar consiste da dimensão social que pode ser representada, em parte, pelo estudo dos níveis de Suporte Social, isto é, os níveis de suporte disponível na rede social de apoio durante todo o ciclo da vida. De acordo com Cobb (1976) o Suporte Social deve estar presente em todo o ciclo de desenvolvimento da vida, porque deve se iniciar no ventre materno com apoio à maternidade, ao nascimento e à nova vida que se inicia, bem como continuar presente ao longo de todas fases de estresse e transições do ciclo de vida.

Em face dessas considerações é possível supor que, ao longo da vida, existam relações entre os níveis de significados transcendentes atribuídos à vida e os níveis de bem estar. Além disso, pode-se supor que, nas relações entre os níveis de sentido transcendente e os de bem estar, seja o apoio social um mediador preventivo do estresse, capaz de favorecer a manutenção dos níveis felicidade e também possa ser considerado como um pilar que sustenta as pessoas a continuarem expressando seus significados transcendentais, mesmo em situações de estresse. 
Nesse contexto, o objetivo deste estudo consistiu em verificar como essas relações acontecem, bem como refletir brevemente sobre as consequências que elas têm sobre as intervenções de Suporte Social nos contextos organizacional e clínico.

\section{FUNDAMENTAÇÃO TEÓRICA}

A Vontade de Sentido é definida como sendo de natureza inata e primária e, portanto, pré- existente a todo aprendizado, memória ou consciência e, por isso, não está sujeita aos movimentos biológicos ou mecânicos materiais. Da falta de contato com o sentido surge o vazio existencial ou frustração existencial, da qual decorre a neurose noogênica de origem espiritual que se caracteriza pela sede de significado e de valor e se apresenta como um substitutivo do sentido. (Frankl, 2003a; Rodrigues, $R, 1991)$.

Nessa acepção, a capacidade de alguém existir ou viver feliz e saudavelmente, ao invés de apenas subexistir ou sobreviver aos desequilíbrios e doenças, estaria associada à capacidade de autotranscendência. A autotranscendência diz respeito ao sentido que uma pessoa encontra em consagrar-se, na vida cotidiana, a algo maior do que ela mesma, como a dedicação à realização de algo para outro ser humano ou à uma causa ou a dedicação à uma pessoa amada. A vivência da autotranscendência tem como consequência um senso de identidade, de autorrealização e de felicidade.

Frankl (2013) afirma que os desejos de poder e de prazer ou vontade de poder e vontade de prazersão manifestações secundárias ou derivações da vontade primordial de sentido. Em sua cosmovisão, a Vontade de Sentido é definida como sendo "o esforço mais básico do homem na direção de encontrar e realizar sentidos e propósitos". Nesse contexto, o poder é um meio para encontrar a finalidade que é o próprio sentido; e o prazer é um efeito do sentido encontrado. Além disso, esse autor afirma que da vontade de sentido emanam a motivação ou "uma razão para ser feliz" e a própria busca pela felicidade.

Estudo de Oliveira e Silva (2013) com 146 idosos mostrou que há uma associação fortemente significativa e positiva $(r=055)$ entre bem estar psíquico e a presença do sentido entre os idosos pesquisados. Além disso, os autores destacaram que o idoso pode encontrar sentido para sua vida, sobretudo se ele tiver a percepção de que está socialmente apoiado, contudo esses recursos sociais não sãoplenamente 
responsáveis pelos índices positivos encontrados, mas sim a qualidade das relações que podem favorecer a emergência do sentido. Este estudo sugere que os significados que dão sentido à vida são capazes de influenciar e portanto em parte proporcionar os bons níveis de bem estar psíquico constatados.

Estudo de Simões, Kluppel e Sousa (2012) com 92 psicólogos de hospitais públicos com idade entre 24 a 60 anos mostrou, entre outros, que o Bem Estar Existencial está significativamente e negativamente correlacionado com os indicadores de exaustão emocional $(r=-0,43)$ e positivamente relacionado com os indicadores de realização profissional $(r=0,42)$, mostrando com isso que há uma tendência de que quando há bons índices de Bem Estar Existencial ocorra baixos níveis de exaustão e aumento dos sentimentos relativos à realização profissional. Este estudo sugere que os significados existenciais sejam um fator de influência que cause, pelo menos em parte, os menores índices de exaustãoe portanto de maior bem estar e de maiores níveis de autorrealização.

Estudo de Walendy de Freitas (2014) com 205 trabalhadores na ativa e aposentados entre 16 a 88 anos mostrou que há relações de influência significativas e diretas entre o Bem Estar Espiritual, o Psicológico e o Subjetivo. Esse estudo mostrou que, além dessas influências diretas, o suporte social também contribui como um mediador entre essas relações. Além disso, o estudo mostrou que os níveis de percepção de suporte social e das três dimensões de bem estar: espiritual, psicológico e subjetivo são significativamente maiores quando o indivíduo tem uma percepção de que sua saúde é boa.

Em face das constatações dessas pesquisas, que analisaram a felicidade em termos de conceitos psicológicos de bem estar, bem como do modelo proposto pela Logoterapia em que a felicidade é o produto do sentido, é possível supor que o sentido atribuído à vida seja um antecedente causal do bem estar.

\section{CONCEITOS SOBRE BEM ESTAR}

Há dois conceitos que fundamentam os estudos psicológicos sobre a felicidade: o conceito de Bem Estar Psicológico e o de Bem Estar Subjetivo. O conceito de Bem Estar Psicológico surgiu com baseem teorias humanistas que envolvem formulações sobre o desenvolvimento humano e atitudes ante os desafios existenciais da vida. 
O conceito de Bem Estar Subjetivo é definido em termos de reações emocionais e de satisfação com a vida. Além dessas duas formulações, há o conceito de Bem Estar Espiritual relacionado aos significados transcendentais associados à religiosidade e aos sentidos existenciais atribuídos á vida.

O Bem Estar Psicológico é um conceito que expressa a percepção que as pessoas têm do próprio envolvimento com desafios existenciais da vida e, sendo assim, tem por finalidade expressar o grau de funcionamento psicológico. Esse conceito é definido por seis dimensões que refletem seis maneiras diferentes de agir, de forma positiva, quando em confronto com os desafios da vida. Essas seis dimensões são: autonomia, domínio do ambiente, crescimento pessoal, relações positivas com os outros, o propósito na vida, e autoaceitação. A autonomia é definida em termos de níveis de pensamento de autodeterminação e independência; capacidade de resistir à pressão social; e capacidade de regular o próprio comportamento a partir do interior, da própria subjetividade. Domínio ambiental é definido em termos de níveis de um senso de domínio e competência na gestão do meio em que alguém atua; no controle do complexo conjunto de atividades externas ao fazer uso efetivo de oportunidades que existem ao redor; e de níveis da capacidade de escolher ou criar contextos adequados às necessidades externas em consonância com os valores pessoais. O crescimento pessoal é definido em termos de níveis de sentimentos de estar em contínuo desenvolvimento, crescimento e expansão; de ter abertura a novas experiências; e de capacidade de realizar o próprio potencial. Relações positivas com os outros é definido em termos de níveis de satisfação e confiabilidade nos relacionamentos; de níveis de preocupação com o bem estar dos outros; e de níveis de empatia, afeto e intimidade para com os outros. Propósito na vida é definido em termos de níveis de crenças sobre a finalidade da vida; objetivos na vida; e um senso de direção, bem como de sentimentos sobre o sentido da vida presente e passada. A autoaceitação é definida em termos de níveis de atitudes positivas em relação a si mesmo; reconhecimento e aceitação de vários aspectos do self, incluindo boas e más qualidades; e os níveis de sentimentos positivos sobre a vida passada (Ryan \& Decy, 2001; Keys, Shmotkin \& Ryff, 2002; Diener et al, 2009; Walendy de Freitas, 2014).

De acordo com Diener, Suh e Oishi (1997) Bem Estar Subjetivo é um campo de estudo da psicologia que tem por finalidade compreender os processos subjetivos 
de avaliação que as pessoas fazemsobre suas vidas em termos cognitivos e em termos de experiências afetivas, mais especificamente no quediz respeito aos níveis emocionais e aos sentimentos de satisfação com a vida. Nesse sentido, Bem Estar Subjetivo é um conceito definido como sendo a avaliação a respeito das próprias respostas emocionais (positivas e negativas) que as pessoas dão, no dia a dia, e acerca de julgamentos de satisfação quanto aos domínios específicos da vida e julgamentos de satisfação global com a vida. Estas avaliações incluem julgamentos afetivos, como alegria e tristeza; a satisfação com os domínios específicos da vida, tais como a satisfação com o trabalho, relacionamentos, saúde, recreação, propósito e outros domínios importantes;e satisfação global com a vida atual, com o passado, com o futuro, e com a própria capacidade de mudar de vida e outros pontos relevantes (Diener \& Ryan, 2009; Pavot \& Diener, 2008; Diener, Suh, Lucas \& Smith, 1999; Chmiel; Brunner; Martin \& Schalke, 2011; Walendy de Freitas, 2009; 2014).

Estudo de Keys; Ryff \& Shmotkin, (2002) mostrou que o Bem Estar Psicológico e o Subjetivo sãodois conceitos distintos que são significativamente e positivamente relacionados.

O conceito de Bem Estar Espiritual é definido pelos aspectos transcendentes e significativos da religiosidade e da espiritualidade. De acordo com Ellison (1991; 1998) refere-se à experiência que as pessoas têm que pode ser denominada de espiritual e nesse sentido é um conceito que envolve duas dimensões: a religiosa e a existencial do bem estar. Bem Estar Religioso enfoca os significados e sentimentos relacionados à Divindade; e a dimensão existencial inclui significados e sentimentos relativosà forma como alguém aprecia e dá sentido à vida. A dimensão religiosa do conceito é expresso em termosde níveis de crença sobre o amor os cuidados de Deus para com o indivíduo, níveis de satisfação na experiência da prece, bem como em níveis de sentimento que há uma relação significativa com Deus. A dimensão Existencial do conceito é expressa em termos de níveis de apreciação da vida e crença de que ela é uma experiência positiva, com um propósito e sentido existencial definidos e níveis relativos ao sentimento de estar bem e tranquilo quanto ao futuro.

Estudo de Ellison (1991) mostrou que os indivíduos, com forte fé religiosa que Ihes confere sentido à vida, relatam níveis mais elevados de satisfação com a vida, maior felicidade pessoal, e menos consequências psicossociais negativas de eventos de vida traumáticos. 
Marques, L. F.; Sarriera, J. C.; Dell'Aglio, D. D. (2009) adaptaram e validaram a escala de Bem Estar Espiritual para a realidade Brasileira. Com base nesse escala, Marques (2003) investigou a relação entre o Bem Estar Espiritual e a saúde geral. Os resultados mostraram que há uma correlação positiva e significativa entre a saúde e - Bem Estar Espiritual. A aplicação deste estudo aponta para a necessidadede inclusão da espiritualidade na concepção de saúde combinado com domínios biológicos, psicológicos esociais, bem como confirma que a espiritualidade pode dar um contributo importante para a promoção da saúde e prevenção de doenças.

\section{CONCEITO DE SUPORTE SOCIAL}

Segundo a definição de Cobb (1976) o Suporte Social é definido como sendo aqueles recursos provenientes de outras pessoas, que levam o indivíduo a acreditar que é alvo de cuidados, que é amado, estimado, bem como, a sentir que é um membro pertencente a uma rede de apoio mútuo. Segundo o modelo de estudo desenvolvido por Cohen e Mckay (1984), esses recursos de apoio, cuja função é a proteção dos efeitos do estresse em situações críticas, são de três tipos: recursos de apoio tangível ou material; recursos informacionais ou de avaliação cognitiva; e recursos de avaliação emocional. O suportetangível ou material é um protetor de estresse que consiste de ajuda financeira, cuidados e outras formas de assistência material. Destaca-se que esse tipo de ajuda somente é efetivo quando não cause constrangimento ou perda de liberdade que acentue o estresse. O suporte de avaliação cognitiva é um mecanismo que enfatiza a avaliação dos aspectos externos da situação estressora. Consiste de informações que podem ajudar uma pessoa a avaliar o evento estressor de forma menos ameaçadora e mais benigna. Quando um evento é avaliado como ameaçador e uma resposta de enfrentamento apropriada não é disponível ocorre uma reação de estresse. O suporte emocional é um mecanismo que enfatiza a avaliação que as pessoas fazem de seus sentimentos a respeito de si próprios e consiste de informações relativas à melhoria da autoestima e do sentimento de pertencer a um grupo.

Estudos sobre intervenções de suporte social mostram que os recursos de apoio são positivamentee significativamente associados a melhores níveis de saúde e de bem estar (Rodriguez \& Cohen, 1998) eo estudo de Gallagher \& Vella-Brodrick 
(2008) mostrou que o suporte social influencia significantemente e positivamente o bem estar.

Rabelo e Néri (2006) afirmam, com base em seu levantamento de estudos brasileiros e estrangeiros, que as pessoas afetadas por acidente vascular cerebral AVC - apresentam menor bem estarsubjetivo com relação à população em geral, contudo ressaltam os autores que os dados apontam para o fato de que a boa capacidade cognitiva, o suporte social efetivo, a continuidade de uma ocupação produtiva, a manutenção da competência em atividades da vida diária e humor positivo são fatores que melhoram o bem estar subjetivo dessa população.

\subsection{Paradigma Lifespan e teoria da seletividade socioemocional}

Teorias baseadas no paradigma de desenvolvimento LifeSpan consideram que fatores associados ao decorrer do tempo, tais como a idade, são indicadores para estudos relativos à constância e mudança no comportamento ao longo da vida. Baseada na visão LifeSpan, a Teoria da Seletividade Socioemocionalsustenta que, com o avançar da idade as pessoas tentam selecionar alvos, situações e relações sociais que thes proporcionem experiências emocionais significativas, decorrendo disso a possibilidade de um funcionamento social e emocional semelhante ou melhor do que os dos adultos mais jovens. Pesquisas têm mostrado que a frequência de emoções negativas tende a diminuir proporcionalmente ao avanço da idade porque idosos tentam manter sua mente mais atentos a memórias e informações positivas, bem como tendem a não prestar atenção a informações negativas, contudo essa tendência a ser mais positivo na idade avançada depende também de outros fatores e experiências que ocorreram na infância e fase adulta. (Charles \& Carstensen, 2010 ) .

As repostas emocionais positivas e negativas são dois componentes do conceito de Bem Estar Subjetivo. Partindo-se do princípio da Logoterapia de que o bem estar é uma consequência do sentido e, levando-se em conta os resultados que mostram que os índices de emoções negativas tendem a diminuir com o avanço da idade, porque os idosos tendem a focar sua mente em memórias e informações mais positivas, é possível supor que isso se deva ao fato de que, com o passar do tempo, as pessoas mudem sua visão sobre a vida, decorrendo disso a hipótese de que tanto 
o bem estar quanto os significados existenciais devam apresentar níveis diferenciados em função da idade.

\subsection{Pressupostos de análise}

Os estudos e reflexões aqui mencionados, levaram à suposição de que existiriam relações de influência entre o Sentido atribuído à vida, o Bem Estar e o Suporte Social ao longo do ciclo de vida. A fim de verificar essas relações de influência utilizou-se como representante para o Sentido atribuído àvida a Dimensão Existencial do Bem Estar Espiritual e a Idade para representar o indicador da constância e mudança na subjetividade ao longo do ciclo da vida. Além disso, optouse por distinguir, no modelo, as questões referentes ao Sentido e apreciação da vida das referentes aos sentimentos de estar bem e tranquilo quanto ao futuro. A Tabela 1 apresenta o esquema da hipótese de antecedência e consequência entre as variáveis assumidas neste estudo e a Tabela 2 apresenta os fatores que compõem as variáveis de estudo.

Tabela 1: Hipótese de Antecendência e Consequência entre as Variáveis de Estudo.

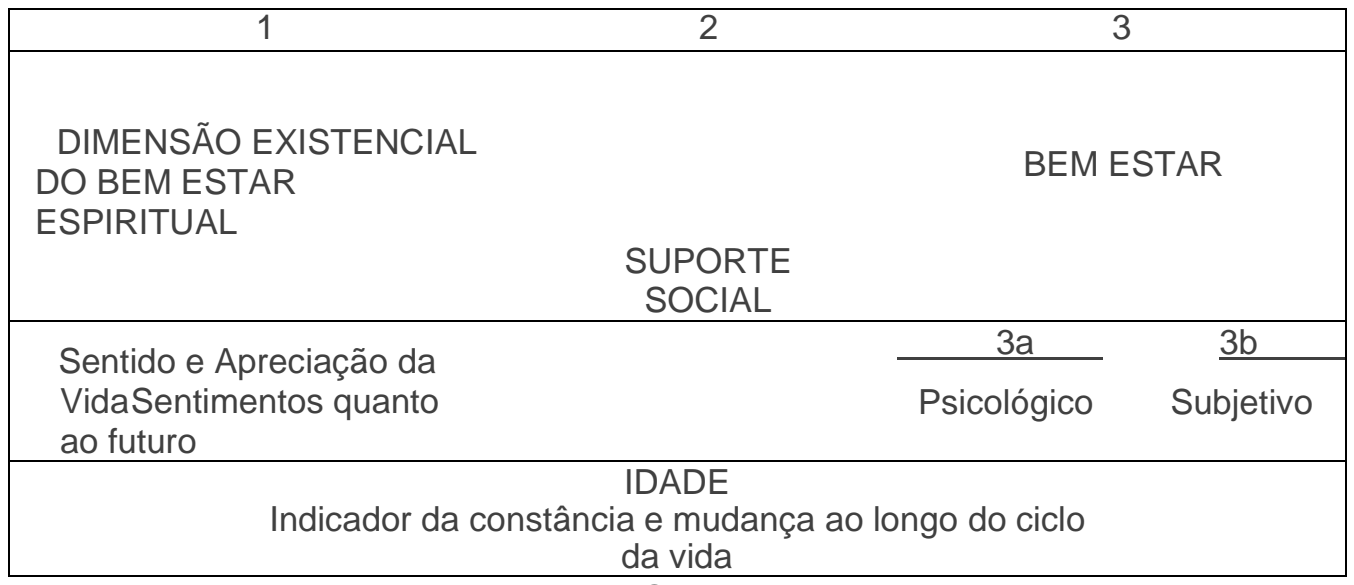

Fonte: Os autores.

Tabela 2: Fatores que compõem as variáveis de estudo

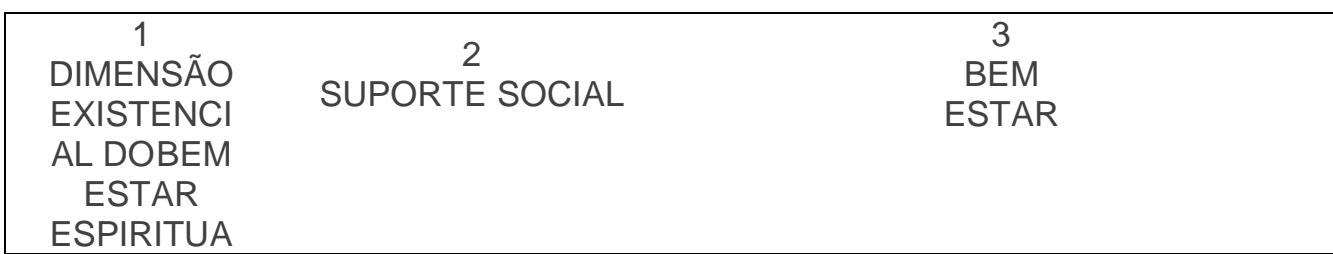




\begin{tabular}{|c|c|c|c|}
\hline $\mathrm{L}$ & & & \\
\hline $\begin{array}{l}\text { Sentido e } \\
\text { Apreciação de } \\
\text { Vida:A vida tem } \\
\text { muito sentido. } \\
\text { Sei quem sou, de } \\
\text { onde vim/vou. } \\
\text { Há um } \\
\text { verdadeiro } \\
\text { propósito } \\
\text { p/minhavida. } \\
\text { A vida é cheia de } \\
\text { felicidade. } \\
\text { Sinto-me } \\
\text { bastante } \\
\text { realizado/satisfeit } \\
\text { o. } \\
\text { A vida é uma } \\
\text { experiência } \\
\text { positiva.Aprecio } \\
\text { muito a vida } \\
\text { Sentimentos } \\
\text { Quanto ao } \\
\text { Futuro: } \\
\text { Sinto-me bem } \\
\text { quanto ao meu } \\
\text { futuro. Sinto bem } \\
\text { estar c/o rumo } \\
\text { de minhavida } \\
\text { Sinto-me } \\
\text { tranquilo com } \\
\text { meu futuro }\end{array}$ & $\begin{array}{l}\text { Prático } \\
\text { Ajuda concreta e } \\
\text { Informações cognitivas } \\
\text { que ajudam a pessoa } \\
\text { sentir que o estressoré } \\
\text { menos ameaçador } \\
\text { Emocional Informações } \\
\text { cognitivas que } \\
\text { favorecem a pessoa a } \\
\text { se sentir amada e } \\
\text { pertencente a uma } \\
\text { rede social de ajuda } \\
\text { mútua } \\
t\end{array}$ & $\begin{array}{l}\text { 3a Psicológico } \\
\text { Propósito Autonomia } \\
\text { Autoaceitação } \\
\text { Relações positivas } \\
\text { c/outros } \\
\text { Crescimento pessoal } \\
\text { Domínio do ambiente } \\
\end{array}$ & $\begin{array}{l}\text { 3b } \\
\text { Subjetivo Afetos } \\
\text { positivos Afetos } \\
\text { negativos } \\
\text { Satisfação global } \\
\text { c/vida } \\
\text { Satisfação c/ } \\
\text { domínios } \\
\text { específicos da vida }\end{array}$ \\
\hline
\end{tabular}

Fonte: Os autores.

\section{MÉTODO}

\subsection{Participantes}

Participaram da pesquisa 205 trabalhadores de empresas privadas e públicas, na ativa e aposentados, bem como trabalhadores autônomos com a idade de 16 a 88 anos. A idade média foi de 40,7 anos, dos quais $65,4 \%$ do sexo feminino e $34,6 \%$ masculino; $41 \%$ casados, $40,0 \%$ solteiros, $12,7 \%$ divorciados, $7 \%$ viúvos e $4 \%$ outros tipos de vínculo. Quanto às religiões professadas: Espiritismo:23,0\%; Catolicismo: 20.6\%; Espiritualista ou Ecumênico ou professando duas ou mais religiões: 13.9\%; sem religião mas acreditam em Deus: 11.2\%; Evangélicos ou Protestantes: 10.8\%; Religiões Afro e outras: 2.0\%; sem informação: 18.5\%. 


\subsection{Medidas}

Os participantes foram solicitados a responder cinco questionários de autopreenchimento desenvolvidos e validados para o Brasil descritos a seguir:

\subsection{Dimensão para medir o bem estar existencial}

Escala de Bem Estar Espiritual é composta por duas dimensões a religiosa e a existencial. Neste estudo utilizou-se somente a dimensão existencial por apresentar questões que representam o sentido atribuído à vida. Esta escala que foi desenvolvida e validada por Marques; Sarriera \& Dell'Aglio (2009) mede os níveis de concordância ou discordância sobre 20 declarações (discordo totalmente = 1; discordo mais do que concordo $=2$; discordo levemente $=3$, concordo parcialmente $=4$, concordo mais do que discordo $=5$; concordo plenamente $=6$ ). A dimensão existencial tem 10 itens $(\mathrm{a}=0,92)$, tais como: sinto que a vida é uma experiência positiva; estou preocupado com o meu futuro; acredito que há algum propósito real para a minha vida, sinto-me bem a cerca do meu futuro.

\subsection{Dimensão para medir o bem estar psicológico}

Escala de Bem Estar Psicológico desenvolvida e validada por Queroz \& Neri, (2006) $(a=0,88)$ é composta por 13 itens. Nesta escala os participantes classificam frases que melhor representam como eles veem a si mesmos (muito pouco =1; pouco $=2$; neutro $=3$; muito $=4$; extremamente $=5$ ), tais como: os outros me descrevem como uma pessoa generosa e disposta a compartilhar experiências; sinto que eu sou capaz de decidir por mim mesmo o que é certo; posso atender as múltiplas responsabilidades da minha vida diária; gosto de muitos aspectos da minha personalidade.

\subsection{Dimensões para medir o bem estar subjetivo}

Afetos Positivos e Negativos: escala desenvolvida e validada por Siqueira, Martins \& Moura (1999) com14 itens que medem a frequência de emoções na vida 
diária (nada $=1$; raramente $=2$; neutro $=3$; muitas vezes $=4$; extremamente $=5$ ); Afetos Positivos $(a=0,87)$ tais como satisfação, felicidade, alegria; Afetos Negativos $(a=0,88)$ tais como irritação, depressão, desânimo.

Escala de Satisfação com Vida desenvolvida e validada por Siqueira, Gomide Jr \& Freire (1996) é composta por 15 itens $(a=0.84)$. Esta escala mede a frequência com que o participante se sentiu satisfeito na vida diária (muito insatisfeito $=1$; insatisfeito $=2$; nem insatisfeito nem satisfeito $=3$; satisfeito $=4$; muito satisfeito $=5$ ) através das questões relativas à satisfação com domínios específicos davida relativos à disposição física, relacionamentos, trabalho, lazer, condições financeiras e questões relacionadas à satisfação global com a vida relacionados à capacidade de fazer as coisas que quer no presente; expectativas quanto ao futuro; e satisfação quanto às realizações no passado.

5.6 Dimensões para medir percepção de suporte social

Escala de Percepção de Suporte Social desenvolvida e validada por Siqueira (2008), com duas dimensões que medem a frequência com que os participantes percebem o apoio exterior na vida diária (nunca $=1$; às vezes $=2$; muitas vezes $=3$; sempre $=4)$. A dimensão de Suporte Emocional $(a=0.92)$ tem 10 itens, tais como: quando preciso eu tenho alguém que: comemora comigo minhas alegrias e realizações; compreende meus problemas; me consola quando estou triste. A dimensão de Suporte Prático( $a=0.91)$ tem 19 itens (instrumentais e informacionais), tais como: quando preciso eu tenho alguém que me ajuda a resolver um problema prático; me dá algo que eu preciso; esclarece as minhas dúvidas; dásugestões sobre o meu futuro.

\subsection{Procedimentos}

Os trabalhadores foram solicitados no próprio local de trabalho e ou pela internet a responderem questões sobre dados demográficos e os questionários validados descritos anteriormente.

Para verificar os padrões de influência entre as variáveis estudadas, utilizou-se como modelo de análise o Partial Least Square-Path Modeling (PLS-PM). 


\section{RESULTADOS E DISCUSSÃO}

A partir do modelo de análise referido, PLS-PM, que utiliza a variância como um indicador de influência de uma variável sobre outra, obteve-se as relações significativas apresentadas na figura 1 em termos de porcentagem de influência.

O modelo aplicado revelou que a dimensão Existencial do Bem Estar Espiritual e o Suporte Socialsão capazes de explicar 37,7\% $(p<0,01)$ do Bem Estar Psicológico e 50,8\% ( $p<0,01)$ do Bem Estar Subjetivo. O Suporte Social é capaz de explicar 2,5\% $(p<0,05)$ e 1,3\% $(p<0,05)$ do Bem Estar Psicológico e Subjetivo, respectivamente. Além disso, o Bem Estar Psicológico contribui com mais 10,1\% ( $p<0,01)$ sobre o Bem Estar Subjetivo, revelando que o modelo foi capaz de explicar esta última variável em $60,9 \%$ ( $p<0,01)$. O Suporte Social é explicado pelo Sentido e Apreciação da Vida em $12 \%(p<0,01)$. A Idade foi capaz de explicar somente a dimensão Existencial do Bem Estar Espiritual. Nesse sentido, o modelo mostrou que a idade exerce influência significativa somente sobre os fatores dadimensão existencial do Bem Estar : 6,9\% $(p<0,01)$ sobre o Sentido e Apreciação da Vida e 7,8\% $(p<0,01)$ sobre Sentir-se Bem Quanto ao Futuro.

Esses resultados mostram que à medida que as pessoas amadurecem há uma leve tendência a aumentarem os sentimentos de que a vida tem significado positivo, tem um verdadeiro propósito, bem como sentirem maior tranquilidade quanto ao futuro. O Sentido e Apreciação da Vida predominantementeinfluencia o Bem Estar Psicológico $(29,9 \% ; p<0,01)$ e bem levemente o Bem Estar Subjetivo $(4,2 \% ; p<0,01)$. Isto significa que apreciar e dar sentido à vida aumenta em cerca de um terço os sentimentos e atitudes relativas à autoaceitação, relações positivas com outros, o crescimento pessoal, o domínio do meio ambiente e o propósito, mas aumenta muito pouco a satisfação com a vida e as emoções positivas, bem como diminui muito pouco as emoções negativas. Contudo os maiores níveis de sentimentos e atitudes de autoaceitação, de relações positivas com outros, de crescimento pessoal, de domínio do meio ambiente e de propósito aumentam significativamente $(10,0 \% ; p<0,01)$ a satisfação com a vida e as emoções positivas, bem como diminuem as emoções negativas. Sentir-se bem e tranquilo quanto ao futuro, predominantemente, influencia o Bem Estar Subjetivo (45,3\%; $p<0,01)$ e pouco influencia o Bem Estar Psicológico $(5,2 \% ; p<0,01)$. Isso significa que os fatores hedônicos emocionais positivos e de 
satisfação com a vida sofrem um aumento considerável e as emoções negativas diminuem quando as pessoas podem sentir tranquilidade quanto ao futuro e sentiremse bem quanto ao rumo que suas vidas estão tomando. Contudo os fatores eudaimonicos relativos à percepção que as pessoas têm do próprio envolvimento com desafios existenciais da vida e de seu grau de funcionamento psicológico tais como atitudes de autoaceitação, de relações positivas com outros, crescimento pessoal, domínio do meio ambiente e propósito crescem muito pouco com os sentimentos positivos quanto ao futuro.

Finalmente, pode-se observar que o suporte social, em termos quantitativos, produz poucos efeitos diretos sobre o bem estar 2,6\% e 1,3\% (p<0,05), respectivamente sobre o Psicológico e sobre o Subjetivo. Contudo a percepção de Suporte Social é sensivelmente influenciada $(12 \%, p<0,01)$ pelo sentido e apreciação da vida. Além disso, seu posicionamento no modelo revela que a percepção de disponibilidadede apoio social é um mediador importante entre o sentido e o bem estar. Isso sugere que as pessoas, que encontram sentido em suas vidas, têm mais habilidades sociais e estão mais abertas para distinguir e buscar, quando necessário, o apoio social adequado ao seu bem estar.

A capacidade de Bem Estar Psicológico explicar Bem Estar Subjetivo está de acordo com o estudode Keys; Ryff \& Shmotkin, (2002) que mostrou que o Bem Estar Psicológico e o Subjetivo são dois conceitos distintos que são significativamente e positivamente relacionados.

A função do suporte social encontrada estudo está de acordo com os estudos de Rodriguez \& Cohen, (1998); Rabelo e Néri (2006) em que a mediação do suporte social é um dos fatores fundamentais para proteger a saúde e o bem estar das pessoas, bem como confirma o estudo de Gallagher\& Vella-Brodrick (2008) que mostrou que o suporte social influencia significantemente e positivamente o bem estar.

Os resultados deste estudo também estão de acordo com Charles \& Carstensen (2010) quanto à tendência de que com o passar dos anos as pessoas apresentem níveis de bem estar e de funcionamento psicológico semelhantes ou melhores do que os mais jovens. Contudo o modelo mostrou que esses efeitos benéficos sobre o bem estar são produzidos pelo Sentido, porque à medida que a idade avança, as pessoas tendem a aumentar os níveis de significados essenciais 
atribuídos à vida e, deste modo, passam a aprecia- la e a sentirem-se mais tranquilas quanto ao futuro.

Isso mostra o quanto são importantes as intervenções de apoio social que afirmem a vida, durante todas as fases, como afirma Cobb (1976), mas mostra também o quanto é importante que essas intervenções deem ênfase ao Sentido, a fim de que, com o avanço da idade, as pessoas possam desfrutar de um funcionamento subjetivo mais favorável, apesar das perdas que possam ocorrer na idade avançada.

Finalmente, o modelo confirmou Frankl (2013) em que a felicidade, aqui definida em termos debem estar, é um produto do Sentido, mais especificamente, o sentido existencial atribuído a vida.

Figura 1: Relações de Influência entre sentido atribuiído à vida, suporte social e bem estar ao longo do ciclo de vida adulta. Partial Least Square-Path Modeling (PLS-PM)

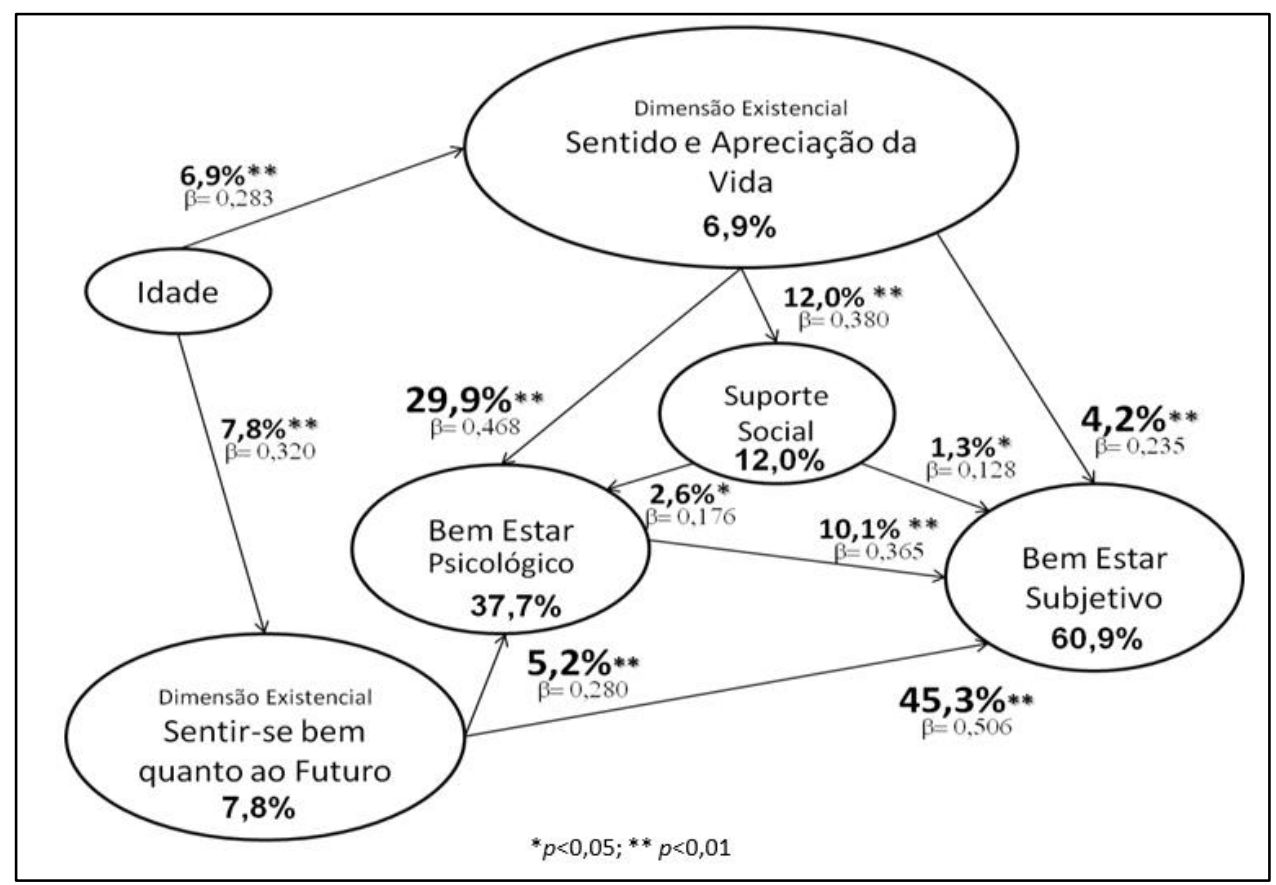

Fonte: Os autores

\section{CONSIDERAÇÕES FINAIS}

As análises deste estudo, baseadas em pesquisas com trabalhadores, apontam para a relevante influência do sentido da vida sobre o bem estar, confirmando o modelo proposto por Frankl (2013) de quea felicidade é uma consequência do 
Sentido.

Este estudo mostra, que à medida que os trabalhadores amadurecem e envelhecem, há uma tendência a aumentar a presença positiva do sentido existencial em sua subjetividade, tanto no que diz respeito a apreciarem e sentirem que a vida é repleta de sentido, quanto a se sentirem bem e tranquilos quanto ao futuro. Essas constatações apontam para a importância da presença de pessoas mais maduras e de idosos, nas empresas, de modo a contribuir, não somente com a experiência técnica, mas também para o desenvolvimento psicológico, para o equilíbrio emocional e consequentemente para o encontro do Sentido que favoreça o enfrentamento mais positivo de problemas no cotidiano da organização. Além disso, mostra que as causas do bom funcionamento psicológico na idade mais avançada, é determinado pelo apoio social não somente na velhice, mas durante todas as fases da vida. Contudo, para ser eficaz é preciso que o apoio social tenha por objetivo principal o despertamento nas pessoas do real Sentido de suas vidas.

Este estudo mostra também que o sentido atribuído à vida é responsável por afetar sensivelmente epositivamente o desenvolvimento psicológico humano e a maneira como as pessoas se defrontam com os desafios existenciais da vida; porque apreciar a vida e acreditar que ela tem um verdadeiro e positivo propósito afeta diretamente o grau de funcionamento psicológico e, por conseguinte, influencia diretamente a percepção e atitudes que elas têm quanto ao próprio envolvimento com desafios existenciais da vida.

Revela também o quanto é importante às pessoas acreditarem que há um futuro promissor que as aguarda, não somente para obterem forças ante os desafios presentes em suas vidas, mas sobretudo, para aumentar a satisfação e reações emocionais positivas diante desses desafios. Essa constatação também sugere que o Sentido seja responsável por reduzir fortemente os níveis de ansiedade e outros sintomas negativos relativos ao futuro.

Além dessas constatações, este estudo confirma que o apoio social é um mediador que facilita às pessoas manterem seu equilíbrio subjetivo e, sobretudo, mostra que o Sentido existencial positivo é responsável por tornar as pessoas mais abertas e mais aptas a perceberem, bem como a buscarem os recursos de apoio que estão disponíveis em sua rede social, quando isso for necessário.

Finalmente, este estudo contribui para mostrar que os serviços de suporte 
social, no contexto clínico ou no contexto organizacional, terão maior êxito se fundamentarem suas intervenções em meios que facilitem para indivíduos e grupos a emergência do Sentido essencial da vida. 


\section{REFERÊNCIAS}

Charles, S.T. \& Carstensen, L.L. (2010). Social and Emotional Aging. Annual Review of Psychology, 61, 383-409.

Chmiel, M., Brunner;M. Martin, R. \& Schalke, D. (2011). Revisiting the structure of subjective Well- Being in Middle-Aged Adults. Social Indicators Research, 106, 109116.

Cobb (1976). Social support as a moderator of life stress. American Psychosomatic Society, 38, 300-314.

Cohen, S.; Mackay, G. (1984). Social Support, Stress and the Buffering Hypothesis: A Theoretical Analysis. In Baum, A.; Taylor, S. E.; Singer, J.E. (eds). Handbook of Psychology and Health. NJ. Hillsdale. 1984.

Diener, E., \& Ryan, K. (2009). Subjective well-being: a general overview. South African Journal of Psychology, 39, 391-406.

Diener, E., Wirtz, D., Biswas-Diener, R., Tov, W., Kim-Prieto, C., Choi, D. \& Oishi, S. (2009). NewMeasures of Well-Bieng. In Diener, E. (Ed), Assessing Well-Being. p.247-266.

Diener, E.; Suh, E. M.; Lucas, E. R.; Smith, H. (1999)Subjective Well-Being: Three Decades ofProgress. American Psychological Association. Psychological Bulletin, v.125, p.276-302.

Diener, E.; Suh, E.; Oishi, S. (1997). Recentes Findings on Subjective WellBeing. Indian Journal ofClinical Psychology

Ellison, C. G. (1991) Religious Involvement and Subjective Well- Being. Journal of Health and SocialBehavior, v. 32,n.1, p.80-99.

Ellison, C. G.; Levin, J. S. (1998) The Religion - Health Connection: Evidence, Theory and FutureDirections. Health Educations \& behavior, v. 25(6), p.700-720.

Frankl, V. E. (2003) Psicoterapia e Sentido da Vida: Fundamentos da Logoterapia e Análise Existencial. Quadrante. São Paulo. 4ª ed. p.55-137.

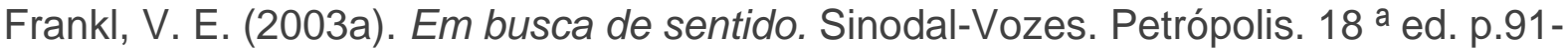
112.

Frankl, V. E. (2013). A vontade de sentido: fundamentos e aplicações da logoterapia. São Paulo. $2^{\mathrm{a}}$ ed. p.48-50.

Gallagher, E. N. \& Vella-Brodrick, D. A. (2008). Social support and emotional intelligence as predictors of subjective well-being. ScienceDirect. Elsevier. Personality and Individual Differences, 44, 1551-156. 
Keys, Shmotkin \& Ryff, 2002; Keyes, C. L. M., Shmotkin, D. \& Ryff, C. D. (2002). Optimizing Well- Being: The Empirical Encounter of Two Traditions. American Psychological Association. Journal of Personality and Social Psychology, 82 (6), 1007-1022.

Marques (2003). Marques, L. F. (2003). A saúde e o bem-estar espiritual em adultos portoalegrenses. Psicologia Ciência e Profissão, 23 (2), 56-65.

Marques, L. F.; Sarriera, J. C.; Dell’Aglio, D. D. (2009). Marques, L. F.; Sarriera, J. C.; Dell'Aglio, D. D.(2009). Marques, L. F., Sarriera, J. C., \& Dell'Aglio, D. D. (2008). Adaptação e validação da Escala de Bem-estar Espiritual (EBE). Avaliação Psicológica, 8, 179-186.

Neri, A. L. (2001) Envelhecimento e Qualidade de Vida da Mulher. Anais do $2^{\circ}$ Congresso de Geriatria eGerontologia. http://scholar.google.com.br/scholar. Acesso em agosto 2009.

Oliveira, E. K. de S. \& Silva, J. P. da (2013). Sentido de vida e envelhecimento: relação entre os pilaresda logoterapia e bem estar psicológico. Logos \& Existência. Revista Da Associação Brasileira De Logoterapia E Análise Existencial 2 (2), 135-146.

Pavot, W. Diener, E. (1993). Review of Psychological Satisfaction With Life Scale. American Psychological Association. Psychological Assesment,.v.5,n.2, p.164-172.

Queroz, N.C.; Neri, A. L. (2005) Bem- estar Psicológico e Inteligência Emocional entre Homens e Mulheres na Meia-idade e na Velhice. Psicologia Reflexão e Crítica 18(2), p. 292-299.

Rabelo, D. F.; Neri, A. L. (2006). Bem-estar Subjetivo e Senso de Ajustamento Psicológico em Idososque Sofreram Acidente Vascular Cerebral: Uma Revisão. Estudos de Psicologia, 11(2), p. 169-177.

Rodrigues, R. (1991). Fundamentos da Logoterapia na clínica psiquiátrica e psicoterapêutica. Petrópolis. Vozes. v.1. p.56-69.

Rodriguez, M., \& Cohen, S. (1998). Social Support. In Friedman, H. (ed.) Encyclopedia of Mental Health. New York: Academic Press. p. 535-544.

Ryan, R. M. \& Deci, E. L. (2001). On happiness and human potentials: a review of research on hedonic and eudaimonic well-being. Annu. Rev. Psychol. 52,141-166.

Simões, A. S.; Kluppel, B. L. P. \& Sousa, S. (2012). Bem estar espiritual e síndrome de bornout em psicólogos de hospitais públicos em João Pessoa/PB. Logos \& Existência. Revista Da Associação Brasileira De Logoterapia E Análise Existencial 1 (2), 192- 202.

Siqueira, M.M.M. (2008). Construção e Validação da Escala de Percepção de Suporte Social. Psicologia em Estudo. 
Siqueira, M.M.M., Martins, M.C.F., Moura, O . I. (1999). Construção e Validação Fatorial da EAPN: Escala de Ânimo Positivo e Negativo. Revista da SPTM. 2. p. 3440.

Walendy de Freitas (2014). The Influence Relations Among Three Traditions of WellBeing and Social Support, and the Associations With Age and Health. In Solano, A. C. (ed). Positive Psychology in Latin America. Dordrecht Heidelberg New York London. Springer. p. 255-273.

Walendy de Freitas, L. H. (2009). Otimismo, Suporte Social e Valores do Trabalho como Antecedentes do Bem Estar Subjetivo de Trabalhadores. Dissertação de Mestrado, Universidade Metodista de São Paulo. 


\title{
CAPÍTULO 03
}

\section{OUTDOOR TRAINING: APRENDIZAGEM EXPERIENCIAL, ITINERÁRIOS DE TREINAMENTO DE GRADUAÇÃO}

\author{
Emilio Ricci \\ Formação acadêmica Master em Terapia Familiar Relacional- Sistémico; Master em \\ Inovação Social \\ Instituição: Universidad Catolica del Norte (UCN) \\ Endereço: Av. Angamos, 0610 - Antofagasta - Chile. \\ Email: ericci@ucn.cl
}

RESUMO: Este capítulo apresenta os elementos teóricos que sustentam a aprendizagem experiencial e sua utilização no desenvolvimento de competências genéricas com alunos de graduação da Universidade Católica del Norte, com base nos quatro elementos básicos da aprendizagem: pensar, observar, fazer e sentir; formação de sensibilização e avaliação por competências. Apoia-se no papel do professor-psicólogo na sua função de facilitador do processo formativo. Por fim, são fornecidos os "componentes" essenciais do treino outdoor que envolvem plenamente a estrutura física, emocional e cognitiva -a intensidade-, com o seu desenvolvimento em espaços naturais (outdoor), alterando os habituais contextos de treino tradicional e perceptivo, suspendendo temporariamente os automatismos e integrando o uso de metáforas em cada desafio que se enfrenta e a elaboração e reflexões com a ajuda de todo o grupo de "classe", para finalmente operacionalizar com os participantes, os processos comunicacionais, relacionais, decisórios e operacionais que se desenvolvem durante o exercício.

PALAVRAS-CHAVE: Outdoor; Aprendizagem experiencial; Treinamento de habilidades.

ABSTRACT: This chapter introduces the theoretical elements that underlie experiential learning and its use in the development of generic competencies with undergraduate students at Universidad Católica del Norte, based on the four basic elements of learning: thinking, observing, doing and feeling; sensitizing the training and evaluation by competences. Support is provided on the role of the teacher-psychologist in his role as facilitator of the training process. Finally, the essential "components" of outdoor training that completely involve the physical, emotional and cognitive structure -the intensity- are provided, with their development in natural spaces (outdoor), changing the usual traditional and perceptive formative contexts, temporarily suspending the automatisms and integrating the use of metaphors in each challenge that is faced and the elaboration and reflections with the help of the whole "class" group, to finally operationalize with the participants, the communicational, relational, decisional and operative processes that take place during the activity.

KEYWORDS: Outdoor; Experiential learning; Skills training 


\section{TRANSFORMANDO A EDUCAÇÃO UNIVERSITÁRIA}

A transição do modelo educacional das universidades - impulsionado pelo processo de Bolonha (1999), cujos objetivos fundamentais estão orientados em três áreas estratégicas: mobilidade, empregabilidade e competitividade - partindo de um modelo, voltado para o ensino, onde a aula magna o método predominante que o identifica claramente; para um modelo centrado na aprendizagem onde os ambientes - em constante transformação e inovação - adaptados às novas realidades sociais da Sociedade do Conhecimento com a integração das TICs, Tecnologias de Informação e Comunicação, também têm estimulado e sobretudo ao mundo acadêmico, lidando rapidamente com a produção de conhecimento a partir de um modelo baseado "por competências" e a integração de novas práticas de formação universitária; entendendo que o processo formação-aprendizagem incorpora o aluno como sujeito ativo do conhecimento e que, além disso, essa adaptação envolve fundamentalmente mudanças nos modelos educacionais com a incorporação de novas metodologias de ensino, mudanças nos usuários da formação e na forma de concebê-los, mudanças nos cenários de aprendizagem e sua adaptação ao mundo real, além de garantir processos de aprendizagem e gestão da qualidade.

Também na América Latina, foram ampliados processos e projetos que intensificaram a busca por convergências e desenvolvimento de linguagens comuns em qualificações, processos de formação, objetivos de aprendizagem e competências, por exemplo, o projeto Tuning; que surgiu imediatamente após a Declaração de Bolonha, com o objetivo de contribuir para o desenvolvimento de qualificações convergentes em diferentes disciplinas e processos de formação europeus; com o objetivo de promover a criação de um Espaço Comum de Educação Superior entre a União Europeia, a América Latina e o Caribe. O modelo de trabalho identificou perfis de graduação para posteriormente projetar ou revisar programas, definindo os resultados de aprendizagem e competências esperados como uma primeira etapa (González e Wagenaar, 2008).

Em última instância, esses processos buscam desenvolver uma visão da educação na perspectiva de "quem aprende" (aluno); com uma mudança de paradigma (como indicado acima, da educação centrada no ensino para a educação centrada na aprendizagem). Intensificar uma educação ajustada às necessidades do 
aluno com uma transformação do papel do educador e o foco das atividades educativas para uma mudança na organização da aprendizagem. Tudo isso com o objetivo de proporcionar profissionais de excelência, com um selo de compromisso com o desenvolvimento científico de cada disciplina e com a responsabilidade social e cívica.

Consequentemente, esta renovação metodológica que envolve aprender e, sobretudo, desenvolver competências de forma eficaz, certamente inclui a compreensão de que é necessária uma abordagem abrangente com a incorporação de planos estratégicos e propostas eficazes de inovação metodológica, aliadas a um modelo educacional próprio. "; exigir do professor uma "transformação do trabalho em sala de aula", passando de uma abordagem pedagógica centrada no professor para uma centrada no aluno (Tejada, 2002). Isso permitirá que os participantes desenvolvam amplas capacidades, permitindo-Ihes aprender e desaprender ao longo da vida, utilizando estratégias eficientes que Ihes permitirão se adaptar a situações em constante mudança. Entregar, nos processos de formação-aprendizagem, conhecimentos, habilidades e atitudes que permitam uma maior flexibilidade, essenciais para a resolução de problemas. Modelos integradores de complexidade que invertem o desejo de fragmentação ou "superespecialização e reducionismo que isola e separa" (Morin, 2001); permitindo um conhecimento integrado com uma mobilização e combinação que permita responder a diversas situações em diversos contextos. Ou seja, aprender permanentemente, entendendo o que se aprende para poder adaptá-lo naturalmente a situações que se transformam continuamente (Esteve, 2003).

Em suma, os processos de formação são adequados às exigências geradas pelo contexto da educação atual, entre os quais podemos citar os critérios de qualidade, globalização, flexibilidade, formação continuada, entre outros. Isso significa que as novas gerações de alunos devem desenvolver não apenas aquelas habilidades específicas de sua profissão, mas também aquelas habilidades genéricas que irão garantir um desempenho profissional de sucesso e socialmente responsável (UCN, 2007).

O treino outdoor como metodologia de treino experiencial, constituído por um sistema integrado de actividades, projectado intencionalmente, para a formação e transferência da aprendizagem para a vida quotidiana, para os espaços de trabalho, 
para a vida escolar e principalmente, como é o caso deste artigo, para processos de desenvolvimento - ou aprimoramento - de competências em alunos de graduação. Para o efeito, foi desenvolvido um modelo de formação integrado numa disciplina de licenciatura, transversal a todas as carreiras, que integra o desenvolvimento de "competências genéricas" (comunicação, trabalho em equipa, pensamento crítico, tolerância à frustração) que surgem da caracterização dos pilares fundamentais do Projeto Educacional da UCN.

O processo de formação integrado no modelo de Formação por Competências, propõe o desenvolvimento de competências válidas em todas as áreas de atuação para fazer face a situações diversas e transversais a qualquer profissão. Além disso, a formação geral contribui para o desenvolvimento das capacidades críticas, analíticas e reflexivas dos alunos, proporcionando-Ihes conhecimentos sobre os seus próprios processos relacionais, profissionais e projetos de vida. Desta forma, a formação experiencial incentiva os participantes a abandonar o espaço do "conforto" das salas de aula e dos processos de "formação tradicional", amplamente conhecidos e integrados em espaços alternativos - mais desconhecidos e portanto com mais incertezas; completando-se permanentemente com ações reflexivas sobre suas próprias formas de enfrentar os obstáculos, sobre suas próprias ideias, sobre valores culturais que tradicionalmente influenciam a visão de mundo; confrontar atitudes e comportamentos, ajudando em todos os momentos a "aprender a aprender". Os participantes são estimulados a enfrentar a incerteza do ambiente externo por meio de sua própria criatividade, tenacidade e perseverança; além de sempre manter a concentração nos objetivos a serem alcançados.

O papel do treinador profissional neste contexto é tornar-se um "facilitador" do processo de aprendizagem (Ricci, 2014); contribuir -aos participantes- na reconstrução das experiências vividas, partilhando os elementos positivos e negativos de cada dinâmica do processo experiencial, reforçando finalmente os comportamentos óptimos e os que devem ser promovidos.

O treinamento experiencial mostra o processo de aprendizagem por meio da experiência real do indivíduo, estimulando constantemente a reflexão, validação e internalização de modelos cognitivos e comportamentais eficazes. Além disso, esse modelo mostra-se particularmente eficaz na medida em que se alinha às que são as necessidades e peculiaridades dos sujeitos, principalmente na construção de novas 
identidades profissionais; Assim como a economia e a sociedade mudam quando os fatores de produção mudam, elas se combinam de forma "inédita", permitindo e implementando invenções e inovações e que na prática aqueles que realizam essas ações são os chamados "empreendedores". Mas é importante ressaltar que não poderíamos falar em inovação se a aprendizagem fosse excluída desse processo e, sobretudo, a geração de conhecimento, por consequência.

\section{OUTDOOR TRAINING E DESENVOLVIMENTO DE HABILIDADES}

Por Oudoor training entendemos os processos de formação que aplicam modelos de aprendizagem experiencial são compreendidos e realizados "fora da sala de aula", em contextos naturais ou em circuitos experienciais criados ad hoc. Como elementos essenciais para um processo de treinamento experiencial eficaz é a "metáfora" usada para alcançar a transferência da experiência de treinamento para a vida real. Ou seja, já na escolha e consequente construção das etapas dos "desafios ou desafios", é necessário projetar atividades que sejam capazes de reproduzir as analogias necessárias com os ambientes de origem: trabalho, formação acadêmica, com regras, estilos de liderança, atmosferas e climas relacionais, etc.

Em suma, para as necessidades dos processos de aprendizagem e de desenvolvimento de competências, procede-se a uma análise detalhada das necessidades e objetivos de aprendizagem, a promover ou desenvolver, com os alunos participantes, em conjunto com os docentes responsáveis por cada projeto selecionado, construindo associações entre cada atividade experiencial e os objetivos do processo de aprendizagem. Além de uma avaliação e regulação extrema, para cada desafio proposto, dos níveis de estresse como um processo natural de resposta à necessidade de adaptação e recursos de enfrentamento ao ambiente que deve ser enfrentado, bem como as sequências de tarefas e desafios proposto.

O programa de treinamento experiencial contém uma série de elementos com os quais cada participante deve enfrentar desde a incerteza, realidade, percepção de risco, interação com o ambiente natural, relações interpessoais e momentos de esforço físico e mental, que provocam nos participantes o "ativação" de várias competências, onde a assunção e consequente elaboração dos riscos a enfrentar, permite atingir, como resultado, objetivos e metas que antes se acreditava incapazes 
de atingir. Assim, o papel do psicólogo "facilitador" do processo formaçãoaprendizagem é decisivo no que diz respeito aos momentos de acompanhamento de cada etapa do processo vivencial; estimular a confiança e desenvolver o espírito de equipe, alcançando a cooperação e a complementação entre os membros. Fortalecimento da liderança e capacidade de delegar responsabilidades. Motivar os participantes nos compromissos de desempenho diário. Promover a comunicação e integração entre áreas e membros da equipe. Claramente, os resultados dos processos de aprendizagem experiencial afetam imediatamente os processos relacionais e organizacionais; aumentando, por exemplo, a resistência ao estresse; otimizar a reação de agudeza em engenhosidade e criatividade em situações de pressão e mudança; aumentar a confiança entre os colegas. Em suma, os resultados obtidos com este tipo de experiência têm um impacto positivo e imediato nos participantes.

\section{GERANCIANDO INCERTEZAS EM OUTDOOR TRAINING}

No que diz respeito aos processos de aprendizagem experiencial, e em particular aqueles relacionados aos processos de formação na graduação, estes determinam que os participantes devem se posicionar em um espaço diverso em que normalmente se encontram, para permitir o processo de aprendizagem. A nomenclatura define "metaforicamente" o primeiro espaço, a "zona de conforto" ou "segurança" (Tuson, 1994, vide fig. 1), que é uma zona segura, pois é conhecida diariamente em todas as suas rotinas, mas não muito estimulante. para integrar "novos conhecimentos" e promover mudanças. A zona de aprendizagem também é definida como a zona de "desafio", que devido às suas características vivenciais permite aos participantes autodescobrirem conceitos e critérios que desejam descobrir, reforçar ou desenvolver, proporcionando processos de aprendizagem eficazes e significativos, causando finalmente mudanças em atitudes e comportamentos. Posicionar os participantes na "zona de desafio" significa levá-los a explorar partes desconhecidas de si mesmos, mas carregadas de potencialidades que, efetivamente estimuladas, permitirão o processo de aprendizagem onde criatividade, inovação são competências que se desenvolverão neste especificar zona. Determinar uma maior tranquilidade para transitar com eficácia em cada um dos 
desafios com uma atitude mais receptiva e com a certeza de que o processo de aprendizagem é, sem dúvida, mais significativo.

Figura 1: Curva de aprendizagem

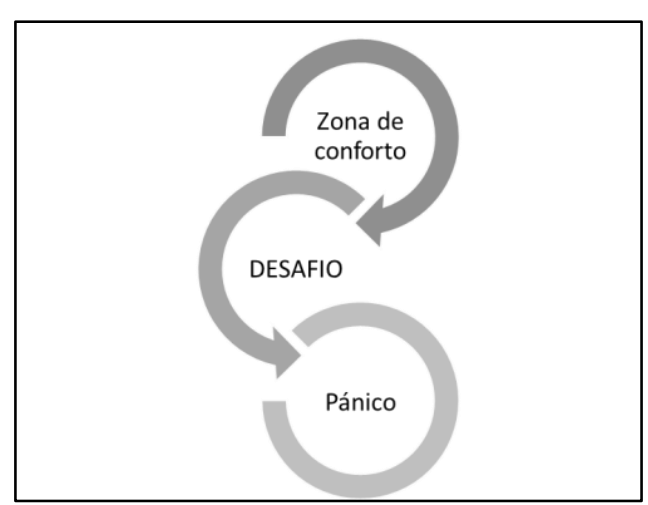

Fonte: Tuson, 1994

Da mesma forma, deve-se ter um cuidado especial para não ultrapassar o limite entre a zona "Desafio" (entendida como desafio) e a "Zona do Pânico", que está imediatamente próxima da zona de aprendizagem. Exigir excessivamente os participantes e levá-los a áreas de pânico ou simplesmente pressioná-los com o único propósito de fazê-los vivenciar áreas desconhecidas seria totalmente inadequado e contraproducente para os processos de aprendizagem metodológica, pois provocaria uma série de sentimentos que poderiam transbordar em magnitude e em consequências negativas para os participantes (medo, vergonha, ridículo, etc.), (Ricci, 2014, ver Fig., 2).

Figura 2: Da zona de conforto para a zona de aprendizagem

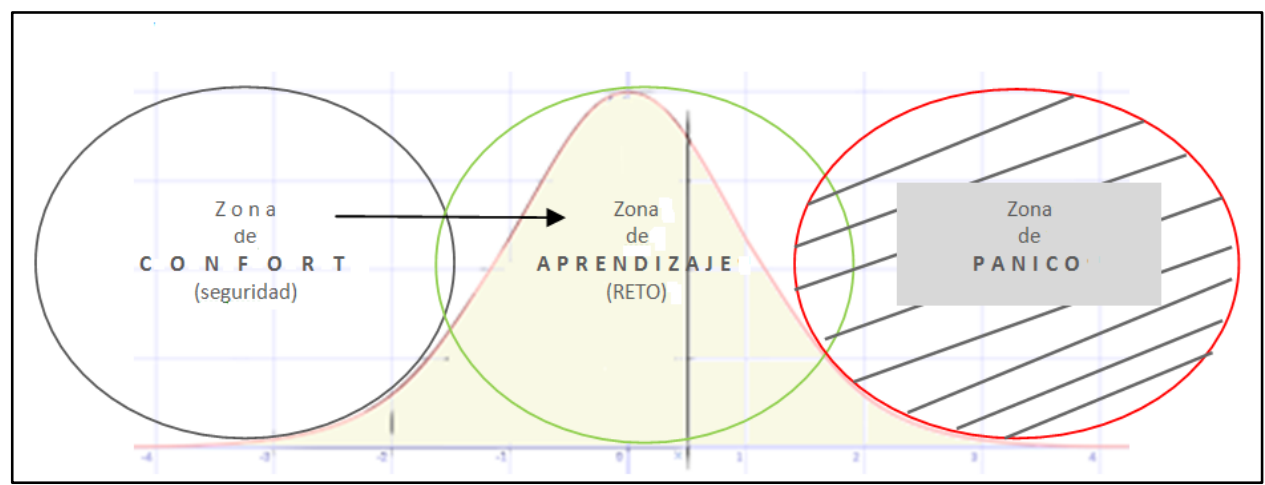

Fonte: Ricci, 2014 
Conforme indicado acima, através dos desafios projetados em um programa de Treinamento ao Ar Livre, os participantes são constantemente "estimulados" a sair da "zona de conforto", para assim explorar as "zonas de desafio" - consequentemente, área de aprendizagem - motivada pela curiosidade, a exigência de formação, projetos de desenvolvimento ou outras circunstâncias de cunho mais pessoal. Já o ambiente natural (circuito experiencial) em que as atividades acontecem é desconhecido para a maioria dos participantes, havendo continuamente a possibilidade de enfrentar riscos inesperados ou calculados; por este motivo também é necessário que os protocolos de segurança sejam suficientemente elaborados e socializados com todos os participantes onde também se pondere a gestão de incómodos e riscos.

Se um participante evita muito entrar na zona de desafio, permanecendo "rigidamente" em sua zona de segurança -conforto-, ele não terá como vivenciar ou vivenciar outros níveis de conhecimento, mas pode ser conduzido durante os processos reflexivos a considerar esses momentos, visto que cada atividade é apenas "meio" e não finalidade dos processos de formação. Pois bem, transitar na zona de desafio significa certamente enfrentar limitações que necessariamente envolvem desconfortos e um não menos intrigante desequilíbrio que resulta na troca de ideias, envolvendo-se em processos com reflexos significativos e num confronto não menos constante e importante com outras pessoas, outras formas de perceber a realidade e, em última instância, novos aprendizados.

\section{OS “COMPONENTES” DE OUTDOOR TRAINING}

O treinamento ao ar livre é diretamente influenciado pelos princípios de Outward Bound (Bank, 1985; Wagner, Baldwing e Roland, 1991; Tuson, 1994; DuFrene, Sharbrough, Clipson e McCall, 1999); cujo termo náutico: limite exterior, representa a bandeira "peter azul", que é hasteada pelos navios mercantes no momento da partida, indicando a "saída da segurança" do porto - do espaço de conforto - para a incerteza do mar aberto.

Nos treinos outdoor, a estrutura física, emocional e cognitiva dos participantes está totalmente envolvida nas atividades realizadas em espaços naturais (outdoor), alterando os contextos perceptuais habituais, suspendendo temporariamente os automatismos e integrando o uso de metáforas em cada prova que ele se depara com 
as consequentes elaborações e reflexões; com a ajuda do profissional-facilitador e de todo o grupo da "turma". Para finalmente operacionalizar com os participantes os processos comunicacionais, relacionais, decisórios e operacionais que decorrem durante a atividade e a possibilidade de transferir tais reflexões -aprendizagem- para as áreas e contextos habituais da vida escolar, familiar e profissional de cada indivíduo.

Reinoso (2006), define o outdoor training como uma metodologia de aprendizagem voltada para a formação de pessoas, e em particular de equipes, especialmente indicada para o desenvolvimento e crescimento de competências emocionais e a transmissão de valores. Portanto, cada atividade Outdoor propõe uma dificuldade - na implementação de desafios ou obstáculos - (ver Fig. 3), que deve ser resolvida (enfrentada) dentro de um determinado tempo e com regras préestabelecidas. A solução parece impossível mesmo quando o grupo com o qual trabalha consegue compartilhar e utilizar todos os seus recursos e habilidades. A solução surge através do reconhecimento e valorização das diferenças pessoais e profissionais e, sobretudo, quando se identificam as dinâmicas de comunicação, comportamentos mais úteis para a concretização de objetivos comuns.

Para efeitos do "circuito de aprendizagem experiencial DelTA UCN", integrou na sua estrutura figuras dos geoglifos ChugChug - o terceiro local com mais geoglifos do mundo, tanto pela concentração dos desenhos como pela variedade deles, mais de 400 figuras, algumas delas datam de 1.000 aC, a maioria delas feitas entre 900 e $1.450 \mathrm{dC}$, construídas pelos povos indígenas da área, Atacameñas e Tarapaqueñas em uma área de evidente mobilidade de caravanas pré-hispânicas - e elementos das ruínas da aldeia de Túlor, - local onde viveu e se desenvolveu uma das mais importantes culturas do Norte Grande há 9 mil anos: o Atacameños e descoberto em 1956- com o objetivo de resgatar o patrimônio histórico-cultural da Região de Antofagasta, afetando significativamente os processos de aprendizagem da cada participante. As figuras integradas no circuito unem literal e metaforicamente cada desafio-teste e projetam os processos reflexivos; permitindo reconhecer e socializar o património histórico da região. 
Figura 3: Circuito de Aprendizagem Experiencial (Implementação no campus da UCN com fundos FIC - R: 2013-2014)

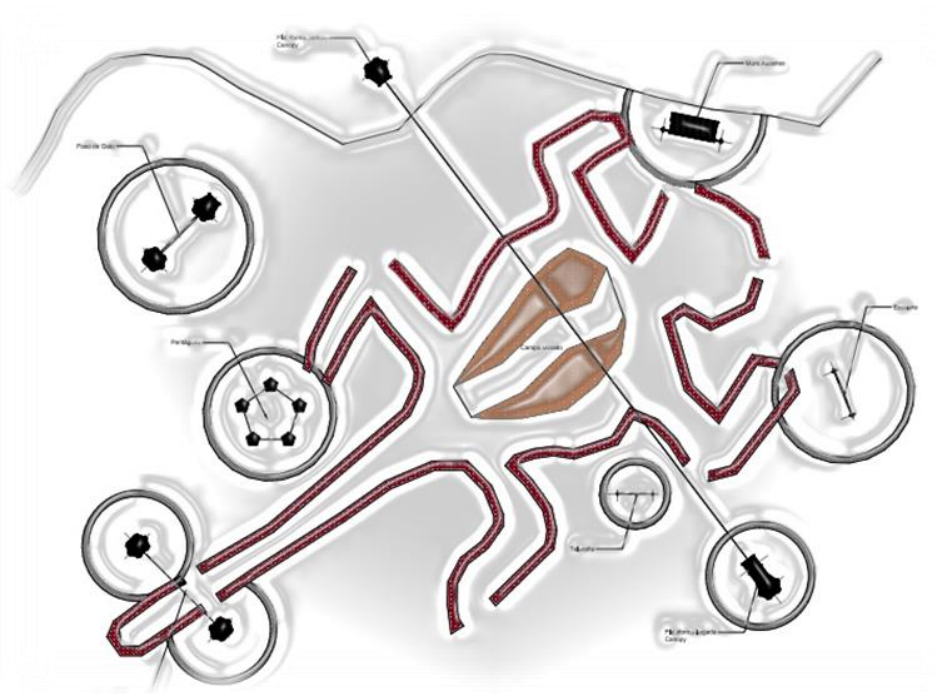

Fonte: Os autores

O processo de aprendizagem vem do ciclo de aprendizagem experiencial de Kolb (Kolb, 1984, Ver Fig. 4), o que sugere que no processo experiencial há uma forma distinta de aprendizagem devido ao papel central que a experiência desempenha no processo. Portanto, para aprender -algo- é preciso trabalhar ou processar a informação que se recebe. É importante ressaltar que é possível partir de uma experiência direta e concreta; ou de uma experiência abstrata, tirada de uma leitura particular ou de uma informação recebida. Desta forma, as experiências vividas, concretas ou abstratas, transformam-se em conhecimento ao serem elaboradas: a). Eles são refletidos e pensados (sobre eles); ou, b). Eles experimentam ativamente as informações recebidas. Mas, para obter uma aprendizagem significativa, é necessário que os participantes se envolvam no processo de aprendizagem: observando, pensando, analisando e participando das diversas atividades do processo para integrar os novos conhecimentos. 
Figura 4: Ciclo de Aprendizagem

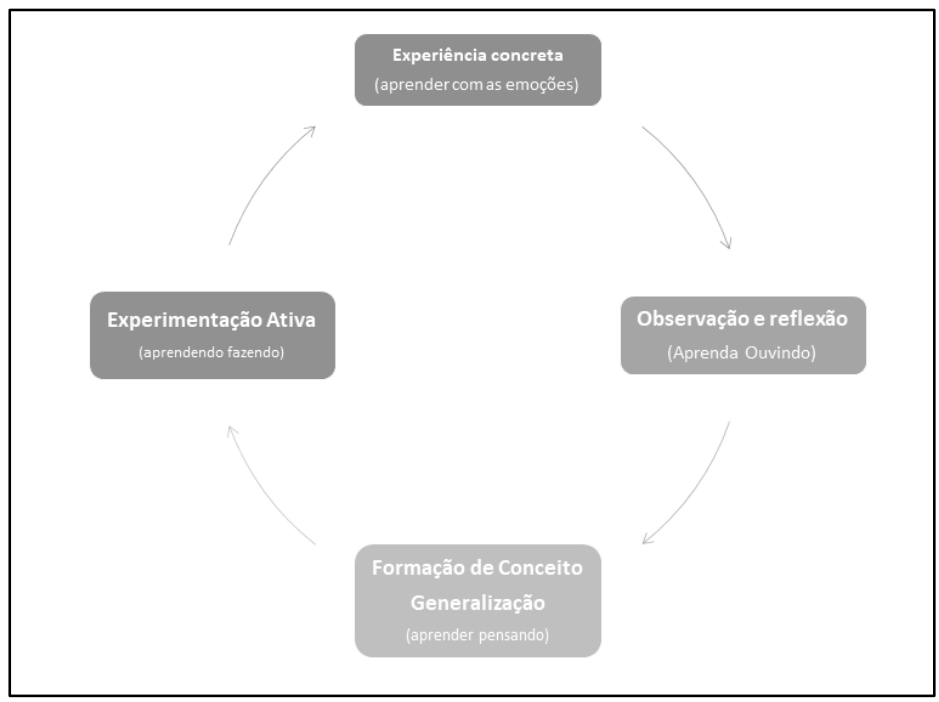

Fonte: Kolb, 1984

É importante ressaltar que o programa outdoor está organizado em uma estrutura flexível que se adapta continuamente às necessidades do "processo de aprendizagem". O tempo e o espaço para o desenvolvimento das atividades devem ser proporcionados de forma a favorecer um ambiente eficaz para que as equipes possam valorizar o que vivenciaram e as mudanças que estão ocorrendo, envolvendo transformações significativas em cada um dos participantes e no grupo em geral. Tal como afirmam vários autores e em vários momentos, os testes propostos para as actividades não são o objectivo fundamental da aprendizagem, mas apenas um meio para a desenvolver, não se trata de os participantes aprenderem a subir ou descer uma parede, mas sim que conseguem trabalhar em aspectos como comunicação, trabalho em equipe, tolerância à frustração, pensamento crítico, etc., etc., (Irvine e Wilson, 1994; Krounwl e Goodwill, 1995; McEvoy e Buller 1997; Shutte, Muktasingh e Whettingsteel, 199; Cobo 2000). Por este motivo, é imprescindível preparar as atividades de acordo com um objetivo pré-estabelecido, bem como os tempos de trabalho com os anexos, etapas reflexivas, fundamentais para potenciar a aprendizagem e as sequências dos processos de formação a desenvolver.

\section{ESTÁGIOS DE OUTDOOR TRAINING}

Etapa preparatória que antecede a atividade Outdoor 


\subsection{Equipe Responsável}

Idealização e elaboração dos objetivos do processo de aprendizagem. Testes de preparação, sequências e tempos de desenvolvimento.

Participantes: Entrega de Cartões de Segurança e Protocolos antes do início das atividades

- Termo de Consentimento Livre e Esclarecido, o procedimento de segurança estabelece o pedido por escrito de autorização para participação em atividades outdoor que estabelece as condições em que os participantes se enfrentarão e as modalidades em que cada indivíduo também poderá participar.

- Arquivo médico, que deve ser compilado por médico que atesta as condições de saúde de cada participante indicando sugestões para a realização de atividades físicas

- Protocolo de segurança, instrutivo que explica e detalha as condições de segurança do circuito experiencial e as condições que cada participante deve usar desde o momento em que entra no local

5.2 Momentos do processo de aprendizagem: Briefing, Playing, Debriefing

Uma vez realizada a primeira etapa e acordado o início da etapa experiencial, os participantes são recebidos com os termos de consentimento devidamente assinados. Após este momento, os participantes são recebidos na entrada do circuito experiencial. Neste momento são lembrados os protocolos de segurança, sequências e horários de trabalho do dia.

- "Quebra-gelo": nesta etapa permitem ao facilitador responsável pelo circuito promover a interação dos participantes, estimulando a reflexão criativa, ilustrando e apresentando a equipe de facilitadores e formando pequenos grupos para iniciar as atividades. Nesta fase, é imprescindível entregar com grande clareza as regras de trabalho estabelecidas e a necessidade de as fazer cumprir, bem como a definição com o grupo dos objetivos de aprendizagem claros e concretos que devem atribuir ao evento, promovendo a participação ativa de todos os participantes.

- Briefing: é o momento em que os participantes são alocados em um pequeno grupo e preparados com os utensílios necessários para enfrentar a atividade. Nesta 
fase de pós-enquadramento, é útil explicar o significado da atividade no que diz respeito aos objetivos de aprendizagem, às regras de segurança e às eventuais comunicações antes de iniciar os testes ou exercícios atribuídos.

- Playing: nesta fase é hora de entrar nas provas e no circuito vivencial que foi criado e preparado para o processo de aprendizagem, onde cada participante se depara e realiza as atividades atribuídas vivenciando a experiência. Neste momento, o papel do profissional "facilitador" é fundamental, auxiliando no desenvolvimento de toda a atividade, recolhendo observações diretas através de uma ficha de observação, elaborada ad hoc, que recolhe entre outros elementos: a dinâmica interpessoal realizada, sobre as atitudes e papéis que surgem durante o processo. Todas essas informações formarão a base para a realização do debriefing na fase final do processo de aprendizagem. O papel do profissional facilitador nesta fase é também supervisionar os protocolos de segurança durante a atividade, que também tem o poder e a responsabilidade de intervir ou interromper as atividades caso o considere adequado ou em função da avaliação de riscos ou perigos posteriores. para os participantes. Nesta fase é fundamental que os participantes descubram "os próprios erros" e no papel de facilitador o profissional pode restringir a sua participação apoiando, reconhecendo esforços ou orientando reflexões ou dando mais informações, mas nunca "criticando as ações" dos participantes. (Beker, 1998)

- Debriefing: É o momento em que o processo é revisitado para demonstrar dinâmicas interpessoais, momentos críticos, até ineficiências; reelaborando as ações nos processos de aprendizagem, oportunidades de desenvolvimento individual do grupo. Se na fase anterior o papel do facilitador era importante, nesta fase é essencial conter e apoiar os participantes para permitir reflexões totalmente sinceras sobre as experiências vividas, solicitando comparações entre sentimentos e opiniões diferentes; direcionando e levando à conclusão de eventuais conflitos. O facilitador deve orientar a reflexão para trazer à tona tudo o que foi observado durante o desenvolvimento das atividades, além de fazer referências às observações coletadas durante a brincadeira, resgatando o feedback sobre as apreciações que os participantes dão sobre si, acompanhando este processo de reflexão. 


\section{CONCLUSIONES}

O "outdoor training" como alternativa de formação e inovação, perfeitamente válida para os processos de aprendizagem e desenvolvimento de competências, permite aprofundar temáticas, mas também descobrir-se, favorecendo o autoconhecimento individual e grupal em determinadas áreas. $O$ valor diferencial desta metodologia supõe não só a atividade "fora da sala de aula" - ao ar livre - ou as atividades recreativas, que sem dúvida constituem o seu principal atrativo, mas não é - de modo algum - o seu objetivo final, que é o suporte - o meio ambiente. - do verdadeiro processo de aprendizagem, que é, em última instância, sua finalidade. Por este motivo, a concepção e desenvolvimento de um treino com metodologia de "treino outdoor" deve ser cuidadosamente preparado para atingir os objetivos programados e garantir a segurança e estabilidade dos participantes em todos os momentos. E quando os objetivos traçados e os conteúdos desenvolvidos são adequados, esta metodologia torna-se uma modalidade de formação extraordinária e inovadora. Caso contrário, continuará a ser considerado mais uma experiência recreativa do que um processo de treinamento e desenvolvimento de habilidades. Por isso, exige a preparação de profissionais que devem realizar certificações ad hoc para a correta aplicação dessas metodologias.

Desta forma, cada análise e os feedbacks que se ativam durante as atividades dos participantes são elementos de complemento e ajudam a acompanhar os processos de aprendizagem. Os dados permitem definir perfis característicos do grupo, enriquecendo também as informações de cada um dos integrantes dos grupos. Desta forma, é extremamente fácil saber quais comportamentos podem ser os mais significativos e quais os menos. Com base nisso, identifique as competências mais sustentadas, ou seja, os pontos fortes, mas também os pontos fracos ou áreas de melhoria.

\section{A NATUREZA COMO SALA DE AULA E A APRENDIZAGEM COMO META}

Como pudemos constatar, o "treino ao ar livre", como modalidade de aprendizagem experiencial, é um programa que utiliza a natureza como sala de aula, o que, pelas condições em que se enfrentam todos os participantes, permite também 
partilhar um nível de incerteza semelhante, bem como a "insegurança", e da mesma forma, ser permanentemente estimulado a desenvolver novas habilidades (Pilonieta, 2002). Além disso, nessas condições, os programas eliminam as barreiras de status ou função que podem existir em outros ambientes (escolar, empresarial, institucional, etc.) e reduzem significativamente as inibições dos participantes, o que incentiva a participação de cada indivíduo e o desenvolvimento de atividades que permitam, por fim, ser totalmente livre e mostrar-se como é, evitando, sobretudo, comportamentos dissimulados (Chulilla, 2002, Stokes, 2008).

A atividade experiencial mostra que o uso da natureza como sala de aula permite aos participantes um contato permanente com o ambiente natural, dando lugar à autodescoberta e à ampla observação de suas próprias forças e fraquezas (Goldenberg, (2001). Ressaltamos que os processos formativos devem incluir processos que desenvolvam a capacidade crítica e reflexiva dos alunos, bem como a tolerância à frustração e resolução de problemas, a par das já assinaladas competências de colaboração e liderança que são os novos desafios de uma sociedade do conhecimento em contínuo transformação e com maiores complexidades, contribuindo com os processos acadêmicos e as demandas de cada raça de origem dos participantes.

A tão questionada educação tradicional, que continuará a ser uma alternativa ("válida?") Para determinadas áreas do conhecimento, proporcionando talvez mais dúvidas entre teoria e aplicação na prática, talvez descaso, e aprendizagens limitadas ao mnemônico eles continuarão sendo considerados pelas novas gerações, no enfrentamento de seu processo formativo. Mas, se queremos alternativas de formação voltadas para a aprendizagem, devemos promover constantemente mais reflexões e mais alternativas de solução de problemas na educação junto aos nossos estudiantes universitarios, atores e sujeitos ativos do conhecimento.

\section{EXTENDED SUMMARY}

The article presents the theoretical elements supporting experiential learning and use in the development of generic skills with undergraduate students at the Universidad Católica del Norte, besides presenting the development processes of personal and group skills under this methodology, providing practical tools that they 
support the utility of self-assessment, personal development and educational experience based on the four basic elements of learning: think, see, do and feel; sensitizing training and competency assessment. Livelihoods on the role of the teacher-psychologist in its role as facilitator of the learning process, in addition to the implications of the implementation of testing and safety protocols developed ad hoc circuit are provided.

Finally the "components" are provide of outdoor training that fully involve physical, emotional and cognitive structure -the intensity- with its development in natural areas (outdoor), changing the usual traditional and perceptual learning contexts, suspending temporarily, operators are provided and integrating the use of metaphors in each test and development faces and reflections with the help of the entire group "class", to finally operationalize the participants, communication processes, relational, decisional and operational activity developed during and the possibility of transferring such - learnings - reflections to common areas and academic contexts, family, work life. 


\section{REFERÊNCIAS}

Ausubel, D.P (1976) Psicología Educativa. Una perspectiva cognitiva. Ed. Trillas. México

Bank, J. (1985). Outdoor Development for Managers. Aldershot, USA: Gower Publishing Company Limited.

Becker, R., (1998), Taking the misery out of experiential training. Training, 35(2) (7888).

Cano García, Mª E., (2008) "La evaluación por competencias en la educación superior". Profesorado. Revista de currículum y formación del profesorado, 12, 3.

Chulilla, B. (2002), El éxito de la conexión outdoor/indoor training. Capital Humano, (153), pp. 58-60.

Dewey, J., (1988), El arte como experiencia. Ediciones Paidos Iberica.

De Marziani, A., Paolino, G., (2002), Fuori dalle aule, fuori dagli Schemi. Storia e contenuti dell'outdoor training. Franco Angeli Ed. Milan.

Dufrene, D., Sharbrough, W., Clipson, T., McCall, M. (1999): Bringing outdoor challenge education inside the business communication classroom. Business Communication Quarterly, 62(3), pp. 24-36.

Esteve, J.M. (2003): La tercera Revolución Educativa. La Educación en la Sociedad del Conocimiento. Barcelona: Paidós

Goldenberg, M.A. (2001): Outdoor and Risk Educational Practices. En A. J. Fedler (Ed.): Defining Best Practices in Boating, Fishing and Stewarship Education. Recreation Boating and Fishing Foundations. Alexandria, VA, pp.129-141.

González, J. y Wagenaar, R. (2008) Universities' contribution to the Bologna process. An introduction. España: Publicaciones de la Universidad de Deusto.

Irvine, D. y Wilson, J.P. (1994). Outdoor Management Development: Reality or Illusion?. Journal of Management Development, 13(5), 25-37.

Kolb, D.A., (2001 “Experiential Learning bibliography 1971-2001”, Boston, Ma.: Mcber and Co.

Kolb, D.A., 1984. "Experiential learning: experience as the source of learning and Development". Englewood Cliffs, New Jersey: Prentice-Hall.

Kolb. D.A., (1981), "Learning styles and disciplinary differences". En A.W. Chichering (ed.) The Modern American College, San Francisco. Jossey-Bass 
Krouwel, B. y Goodwill, S. (1995). Outdoor Training. A Sourcebook of Activities for Management Trainers. London: Kogan Page.

Jenkins, A. 1998. "Curriculum design in geography". Cheltenham: Geography Discipline Network, Cheltenham and Gloucester College of Higher Education.

Lewin, K., (1935), A Dynamic Theory of Personality, McGraw Hill, New York

McEvoy, G. M. y Buller, P. F. (1997). The power of outdoor management development. The Journal of Management Development, 6(3), 208-215.

Ministros Europeos (1999): Declaración de Bolonia.

Morin, E. (2001). Los siete saberes necesarios para la educación del futuro. Barcelona: Seix Barral

Pilonieta, G. (2002): Desarrollo Empresarial. Propuesta de Diplomado en Aprendizaje Experimental. Politécnico Marco Fidel Suárez, Equipo Cisne de Investigación. Bogotá, Colombia

Pimentel, G. E. \& Montt, I. S., (2008), “Tarapacá en Atacama. Arte rupestre y relaciones intersocietales entre el 900 y 1450 DC". Boletín del Museo Chileno de Arte Precolombino, Vol. 13, № 1.

Ricci, E., (2014), "Outdoor Aprendizaje Experiencial: Desde la teoría al desarrollo de competencias en pregrado". IX Congreso Chileno de Psicología. 26-28 noviembre Chillan, Chile.

Reinoso M. (2006), Desarrollo de competencias emocionales en los individuos de una organización utilizando la metodología de formación: OT. Tesis doctoral dirigida por: LATIESA RODRÍGUEZ, M. Departamento de Sociología. Universidad de Granada.

Romero M, Solórzano M., Gutiérrez, M., (2011), "El aprendizaje experiencial como metodología docente: aplicación del método Macbeth". Argos Vol. 28 № 54/ pp. 127158.

Shutte, L., Muktarsingh, N., Whettingsteel, H. (1999). Fun in the name of work. Director, London, (9), 54-58.

Stokes, P. (2008): Outdoor management development as organizational transformation: A study of anglo-french paradoxical experience in the application of alternative human resource development approaches. International Journal of Cross Cultural Management, 8(1), 23-39.

Tejada, J., (2002) «El docente universitario ante los nuevos escenarios: implicaciones para la innovación docente». Acción Pedagógica, 11(2), pp. 30-42

Tuson, M. (1994). Outdoor Training for Employee Effectiveness. London: Institute of Personnel Management. 
Universidad Católica del Norte, (2007). Proyecto Educativo. Ediciones Universidad Católica del Norte.

Wagner, R. J., Baldwing, T. T., Roland, C. C. (1991). Outdoor Training: Revolution or Fad? Training and Development Journal. Marzo, pp. 51-57. 


\section{CAPÍTULO 04}

\section{CriaAnato: PRODUÇÃO DE MACRO MODELOS FOCANDO NA ANATOMOPATOLOGIA DA COVID-19}

\section{Maria Luzinete Batista Barbosa}

Graduanda em Ciências Biológicas pela UFPB

UFPB - Campus I - Lot. Cidade Universitária, João Pessoa-PB

E-mail: luzinetebbarbosa@hotmail.com

\section{Vitória Calixto da Nóbrega}

Graduanda em Ciências Biológicas pela UFPB

UFPB - Campus I - Lot. Cidade Universitária, João Pessoa-PB

E-mail:vcn@academico.ufpb.br

\section{Maryana Marinho Barbosa Bastos}

Graduanda em Odontologia pela UFPB

UFPB - Campus I - Lot. Cidade Universitária, João Pessoa-PB

E-mail: maryana.marinho@academico.ufpb.br

Francisco de Assis Justino de Lima

Graduando em Ciências Biológicas pela UFPB

UFPB - Campus I - Lot. Cidade Universitária, João Pessoa-PB

E-mail: franciscoasjustino@gmail.com

\section{Rebeca Souza Uchoa Oliveira}

Graduanda em Ciências Biológicas pela UFPB

UFPB - Campus I - Lot. Cidade Universitária, João Pessoa-PB

E-mail: rebeca.souza@academico.ufpb.br

\section{Monique Danyelle Emiliano Batista Paiva}

Doutora em Estomatologia UFPB/UFBA Universidade Federal da Paraíba/UFPB

UFPB - Campus I - Lot. Cidade Universitária, João Pessoa-PB

E-mail: moniquedebp@gmail.com

\section{Ana Aline Lacet Zaccara}

Doutora em Enfermagem/UFPB Universidade Federal da Paraíba/UFPB

UFPB - Campus I - Lot. Cidade Universitária, João Pessoa-PB

E-mail: anazaccara@hotmail.com

\section{Anna Ferla Monteiro Silva}

Doutora em Ciências da Saúde/UFRN Universidade Federal da Paraíba - UFPB UFPB - Campus I - Lot. Cidade Universitária, João Pessoa-PB E-mail: annaferlapb@gmail.com

RESUMO: O estudo da Anatomia Humana é imprescindível nos cursos da área da saúde e nas Ciências Biológicas, permitindo aos alunos conhecer macroscopicamente as estruturas que compõem o organismo humano, além de auxiliar no entendimento 
do mecanismo fisiológico, como também, no conhecimento do funcionamento e características das patologias que acometem o corpo humano, com destaque, a COVID-19. Tendo isso em vista, o objetivo deste trabalho é descrever a produção de macro modelos de baixo custo que facilitassem a aprendizagem quanto à anatomia do pulmão e anatomopatologia da COVID-19. Sendo este, um dos produtos do projeto de extensão: CriaAnato, que tem como finalidade integralizar o ensino teórico e prático ao produzir modelos anatômicos didáticos de órgãos humanos através de materiais alternativos, economicamente viáveis e acessíveis, para que estes possam potencializar o processo de aprendizagem tanto dos alunos da UFPB, quanto dos alunos do ensino fundamental e médio de escolas públicas e privadas. Foram confeccionados macro modelos através de materiais de baixo custo como papel, canetas, palitos de churrasco, lápis de cor e cola quente. Em um primeiro momento foi construído um desenho esquemático onde se observava acúmulo de líquido no pulmão e seus alvéolos obstruídos devido a COVID-19. Em um segundo momento construiu-se um macro modelo de um pulmão inflamado em cola quente. Mesmo sabendo que aspectos científicos e patológicos da COVID-19 ainda estão sendo pesquisados, já é de conhecimento que o pulmão é o órgão mais afetado. Na peça procurou-se abordar os aspectos anatômicos resultados da ação viral no pulmão, apresentando um órgão fora de suas condições normais, retratando a fase grave da COVID-19. Estudos apontam que a utilização de meios alternativos para o ensino estimula a inteligência espacial, físico-cinestésica e interpessoal. Além de otimizar a memória acerca do conteúdo ministrado como também na transmissão dos conceitos adquiridos.

PALAVRAS-CHAVE: Anatomia Humana; Arte; COVID-19; Ensino; Modelos didáticos.

ABSTRACT: The study of Human Anatomy is essential in courses in the area of health and in Biological Sciences, allowing students to know macroscopically the structures that make up the human organism, in addition to helping in the understanding of the physiological mechanism, as well as in the knowledge of the functioning and characteristics of pathologies that affect the human body, especially COVID-19. With this in mind, the objective of this paper is to describe the production of low-cost macro models that would facilitate learning about the lung anatomy and anatomopathology of COVID-19. This being one of the products of the extension project: CriaAnato, which aims to integrate theoretical and practical teaching by producing didactic anatomical models of human organs through alternative materials, economically viable and accessible, so that they can enhance the learning process both from UFPB students, as well as from elementary and high school students from public and private schools. Macro models were made using low- cost materials such as paper, pens, barbecue sticks, colored pencils and hot glue. At first, a schematic drawing was constructed showing the accumulation of fluid in the lung and its alveoli obstructed due to COVID19. In a second moment, a macro model of an inflamed lung was constructed using hot glue. Even knowing that scientific and pathological aspects of COVID-19 are still being researched, it is already known that the lung is the most affected organ. In the piece, we sought to address the anatomical aspects resulting from the viral action in the lung, presenting an organ out of its normal conditions, portraying the severe phase of COVID-19. Studies show that the use of alternative means for teaching stimulates spatial, physical- kinesthetic and interpersonal intelligence. In addition to optimizing memory about the content taught as well as the transmission of acquired concepts. 
KEYWORDS: Human anatomy; Art COVID-19; Teaching; Didactic models. 


\section{INTRODUÇÃO}

O estudo da Anatomia Humana é imprescindível nos cursos da área da saúde e Ciências Biológicas, permitindo aos alunos conhecer macroscopicamente as estruturas que compõem o corpo humano, além deauxiliar os futuros profissionais a tomarem uma conduta no que concerne ao diagnosticar, tratar, reabilitar e fazer pesquisa ${ }^{1}$.

O ensino da Anatomia pode se tornar desafiador diante das inúmeras estruturas existentes, além da nomenclatura, dificuldade de visualização e falta de peças para as aulas práticas (e ainda o potencial agravante no qual se configura a crise sanitária atual). Nesse sentido, o aprimoramento de recursos didáticos-pedagógicos, como a confecção de macro modelos anatômicos, aplicado ao ensino da anatomia tem-se revelado como tendência e estimula a construção ativa do conhecimento e a capacidade cognitiva do aluno, suporte este que é indispensável ao processo de ensino e aprendizagem ${ }^{2-5}$.

Segundo Castro (1991), "O papel da Didática na formação do educador é fundamental para ajudá- lo em suas práxis pedagógicas, pois, a contribuição que ela desempenha no campo educacional nenhuma outra disciplina poderá cumprir"6. Portanto, os modelos anatômicos tendem a suprir a necessidade de materiais que auxiliem o aprendizado do aluno, fortalecendo o aprendizado, tendo em vista o fornecimentoao professor de uma via contribuinte para o ensino.

A ativação do desenvolvimento psicológico é um conceito que inclui os procedimentos de "instigar, estimular o desenvolvimento humano em todas as suas dimensões, tendo em conta as suas disponibilidadesmais sensíveis (...) ou abertas dos sujeitos nos seus diferentes estádios ou fases de desenvolvimento"7. Diante disso, otimizar o processo de aprendizagem de forma intencional, inserindo o aluno de forma ativa,pressupõe a importante utilização de bons materiais e métodos para o ensino que exerçam o indispensável papel de motivador.

Um outro apoiador da utilização de diversos meios alternativos para o ensino é Howard Gardner, sua teoria propõe estimular as diversas potencialidades dos alunos, bem como suas inteligências ${ }^{8}$. Nesse sentido, Gardner apoia o fato de considerar cada indivíduo em sua totalidade e diversidade, portanto, torna-se relevante a utilização de peças que incentivem a inteligência espacial, com o uso de materiais diversos que 
serviram para construir uma estrutura anatômica; a inteligência físico-cinestésica, já que é utilizado as mãos para a confecção e ainda, a inteligência interpessoal, pois é possível a confecção em grupo do material proposto ${ }^{9}$.

Em somatório a toda essa discussão levantada, evidencia-se o atual estado de saúde pública. No ano de 2020, uma nova tipologia de Corona Vírus (SARS-CoV-2) vem mostrando um forte impacto na saúde mundial, resultando em mortes em massa e exigindo um isolamento social prolongado ${ }^{10}$. Isso afeta diversos setores da sociedade atual. Dentre eles, a Educação ${ }^{11}$.

Dessa forma, este trabalho beneficia pessoas com e sem necessidades educacionais especializadas de aprendizagem, favorecendo assim a inclusão no que se refere ao entendimento da anatomopatologia da Covid-19, potencialmente grave, de elevada transmissibilidade e de distribuição global.

Tendo isso em vista, objetiva-se com a escrita deste artigo, descrever a produção macro modelos de baixo custo que facilitassem a aprendizagem quanto à anatomia do pulmão e anatomopatologia da COVID- 19, discutindo assim, possibilidades de ensino em diferentes esferas de conhecimento e considerando a situação sanitária atual assim como a sua interferência na educação.

\section{METODOLOGIA}

O projeto CriaAnato foi aprovado pelo edital PROBEX-UPFB 2021 sob número PJ545-2021 e tem como finalidade integralizar o ensino teórico e prático ao produzir modelos anatômicos didáticos de órgãos humanos através de materiais alternativos, economicamente viáveis e acessíveis, para que estes possam potencializar o processo de ensino e aprendizagem tanto dos alunos da UFPB, quanto dos alunos do ensino fundamental e médio de escolas públicas e privadas, além de incentivar o ensino e contribuir no processo de orientação à docência e crescimento acadêmico dos extensionistas. Vale ressaltar, que durante o processo de confecção dos materiais didáticos leva-se em conta a natureza, a durabilidade e o custo do material além dos cuidados necessários para o manuseio das peças sintéticas produzidas.

Sendo assim, para a criação das peças aqui descritas, foram confeccionados macro modelos usando papel, canetas, palitos de churrasco, lápis de cor e cola quente. Nos modelos em questão, são observadas asconsequências da COVID-19 
nos pulmões: Em um primeiro momento foi construído um desenho esquemático em que a aluna utilizou como referência imagens disponíveis na Internet de ilustrações dos pulmões acometidos pelo SARS-COV-2 onde se observa o acúmulo de líquido no pulmão e seus alvéolos obstruídos devido a COVID-19 (figura 1); Em um segundo momento construiu-se um macro modelo de um pulmão inflamado em que a cola quente representa 0 aspecto esponjoso deste órgão e, para representar anatomicamente o vírus, foram utilizados palitos de churrasco cortados (figura 2).

\section{RESULTADOS E DISCUSSÃO}

Figura 1: Desenho esquemático de pulmão com COVID-19 e Modelo em cola de pulmão com COVID19

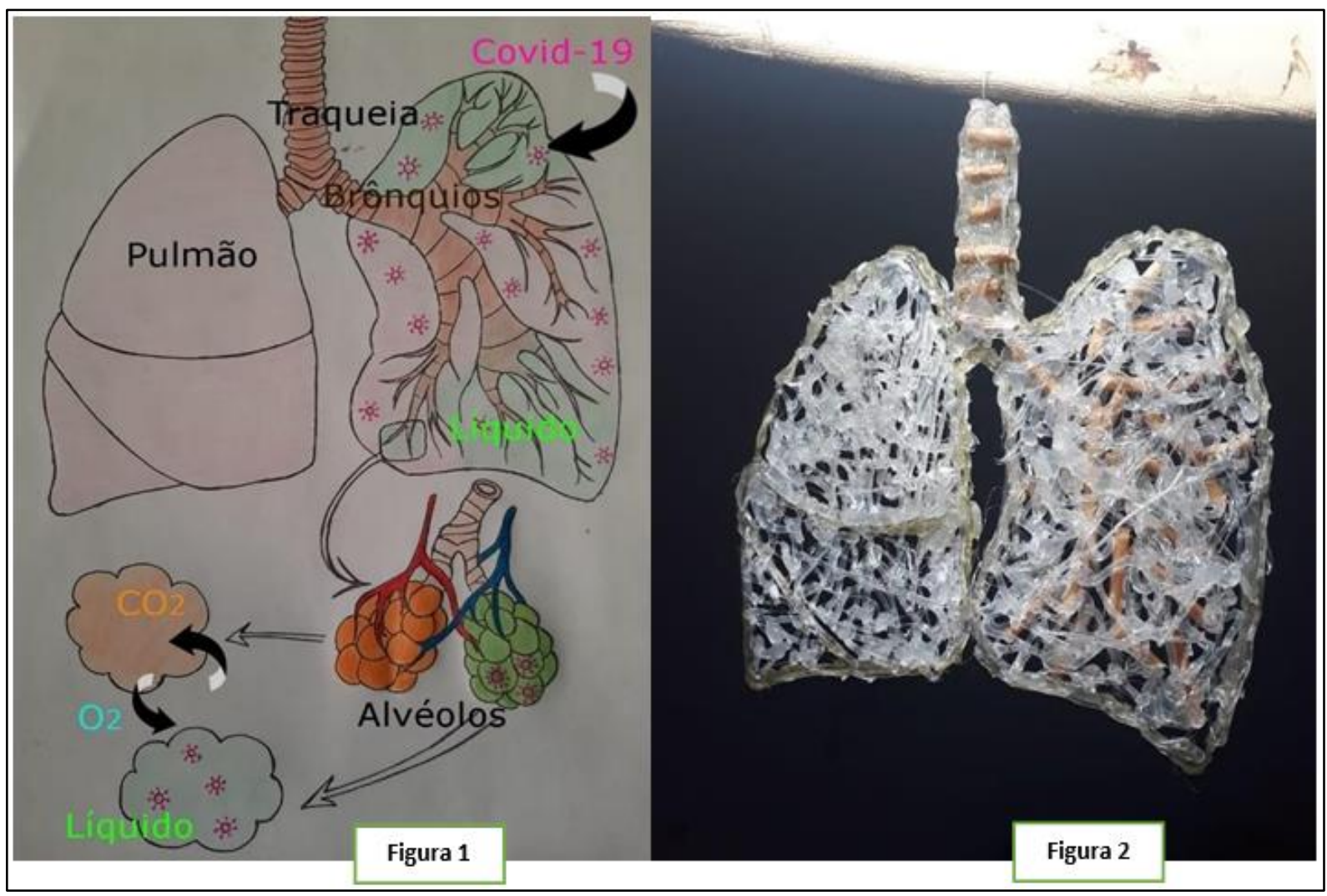

Fonte: Acervo de produção do projeto

O processo de construção do conhecimento exige das pessoas participação da percepção e a estruturação das representações mentais ${ }^{12}$. Segundo Neves (2010) o desenho torna-se signo quando representa algo real, estimulando ao aluno a estudar promovendo a aquisição do conhecimento através da significação do desenho, sendo assim, o autor caracteriza que a atividade do desenho possui uma função 
instrumental, funcionando como suporte para a memória e a transmissão de ideias e conceitos $^{13}$.

Diante disso, e considerando que o primeiro impacto do vírus no corpo é nos pulmões, as representações são fiéis a este órgão. Sabendo que aspectos patológicos da COVID-19 ainda estão sendo pesquisados, já é de conhecimento que o pulmão é um dos órgãos mais afetados. No início da infecção, o SARS-COV-2 tem como alvo as células epiteliais nasais, brônquicas e pneumócitos ${ }^{14}$. Nos estágios posteriores da infecção, o aumento da replicação viral pode desencadear uma resposta inflamatória causando pneumonia devido à congestão dos alvéolos, responsáveis por direcionar o oxigênio ao sangue, o que acarretará insuficiência respiratória do paciente, com evolução para hiperinflamação sistêmica ${ }^{14}$.

Com base em uma pesquisa publicada no Journal of Thoracic Oncology, os pulmões podem apresentar edema e exsudato, alterações estas ligadas provavelmente à fase inicial da patologia pulmonar ${ }^{15}$. Nos modelos criados e descritos, procurou-se abordar os aspectos anatômicos resultados da ação viral no pulmão, apresentando um órgão fora de suas condições normais, retratando a fase grave da COVID-19.

Pacientes com COVID-19 podem ser assintomáticos, oligossintomáticos ou mesmo sintomáticos, estes podem apresentar de sintomas leves a moderados (cerca de $80 \%)^{16}$, entretanto, aproximadamente $15 \%$ dos pacientes evoluem para uma pneumonia grave e cerca de $5 \%$ acabam desenvolvendo síndrome do desconforto respiratório agudo (SDRA), choque séptico ou falência de múltiplos órgãos (CAO, 2020). Essa informação nos leva a reflexão de que também é importante o conhecimento da normalidade previamente, antes do domínio da alteração patológica.

Em resposta ao supracitado na introdução, o conhecimento Anatômico é prérequisito ao conhecimento das patologias por parte dos profissionais da saúde, daí a importância de uma Anatomia bem feita e bem vista. Alguns estudos já vêm falando nos últimos anos sobre metodologias ativas de ensino em Anatomia Humana ${ }^{17,18}$, alguns levando em conta inclusive, a saúde mental dos estudantes ${ }^{19}$. Mas são poucos os que estão emergindo e considerando a situação epidemiológica e educacional atual.

Já é consenso entre profissionais que a COVID-19 não se limita apenas aos 
pulmões, ela é considerada como um mal sistêmico afetando também sistema circulatório, nervoso, demais sistemas e órgãos. No sistema circulatório, o SARSCOV-2 pode elevar o risco de formação de trombos e coágulos, em alguns casos mais sérios os pacientes também sofrem de AVC e infarto ${ }^{16}$.

Com relação ao sistema nervoso, sabe-se que os nervos periféricos responsáveis pelo olfato epaladar são prejudicados, porém, de acordo com uma pesquisa feita pela Universidade de Harvard, nosEstados Unidos, pesquisadores descobriram que o mesmo utiliza dois genes específicos que codificam asenzimas receptoras. Para adentrar nas células humanas o Sars-CoV-2 precisa desses dois genes, o ACE2 eo TMPRSS2, que só são expressos por células de suporte olfativo, e não por neurônios, o que justifica aperda de ambos os sentidos. Problema de memória é também uma das sequelas deixadas pela COVID-1920.Segundo um artigo publicado na American Society of Nephrology, o SARS-COV-2 pode infectar diretamente os túbulos renais humanos, induzindo inclusões citoplasmáticas, a infecção ocorrepredominantemente na superfície apical, mas também pode ocorrer na superfície basolateral de modomenos eficaz. Alguns trabalhos, como o realizado no Nord Franche-Comté Hospital, apresentam pacientescom sintomas como diarreia e vômito, demonstrando que a COVID-19 também ataca o intestino e gera problemas gástricos ${ }^{21}$.

Além disso, sabe-se que é uma doença altamente contagiosa, em 2020, foi caracterizada pelaOrganização Mundial de Saúde (OMS), como uma pandemia. A mesma, possui uma alta letalidade aindivíduos com comorbidades, como hipertensos, diabéticos, cardiopatas e pessoas idosas. Ademais, estudos demonstram que a viabilidade do vírus em tempo, difere do material como a exemplo do metal eplástico. As partículas do vírus podem permanecer viáveis por algumas horas a nove dias, e a viabilidadeviral sujeita-se não apenas ao tipo de material, mas também depende de fatores físico-químicos, comotemperatura e Ph de acordo com estudos feitos e evidenciado no artigo publicado por Xavier et al., (2020) ${ }^{9}$.Diante de toda essa investigação e abordagem da patologia, este foi um estudo descritivo inicial.

Ainda se espera uma maior apuração acerca das implicações clínicas do coronavírus nos demais sistemas para além a formulação de modelos didáticos e posterior descrição dos mesmos. 


\section{CONCLUSÃO}

É fato a iminente gravidade social decorrida da natureza altamente letal e ainda dos riscos que o indivíduo perpassa, caso adquira o SARS-COV-2. Frente a isso, decorre a necessidade de uma ampliação do conhecimento anatômico e sistêmico dessa patologia. Tornando-se imprescindível a adoção de meios alternativos que auxiliem o conhecimento. Estes meios, portanto, servirão de facilitadores do entendimento, visto que da mesma forma que ocorre a ampla divulgação dos mecanismos que impedem o contágio com oCoronavírus (COVID-19), é necessário que $\mathrm{o}$ alunado e a população como um todo, tenha a compreensão das estruturas anatômicas que os compõem e que podem ser afetadas.

Trabalhos e projetos como esses, tem o potencial para conscientização na educação básica, ensino fundamental e médio, além de ajudar na formação dos futuros profissionais da linha de frente. Nos dois ambientes educacionais aqui citados, cabem as palavras de Paulo Freire quando ele diz que "Partamos da experiência de aprender, de conhecer, por parte de quem se prepara para a tarefa docente, que envolve necessariamente estudar" (FREIRE, 2001). 


\section{REFERÊNCIAS}

1. Conselho Nacional de Saúde, Resolução 196/96. Acesso em: 19 de out. 2011.

2. Alves MV. A medicina e a arte de representar o corpo e o mundo através da anatomia. Arte Médica elmagem do Corpo: de Hipócrates ao final do século XVIII Biblioteca Nacional de Portugal, 2010.

3. Silva MSL, et al. Produção de material didático alternativo para aula prática de anatomia humana. In:VII Congresso Norte Nordeste de Pesquisa e Inovação, 2012, Palmas, Tocantins(Anais): VII CONNPI.

4. Silva AA, et al. O uso do biscuit como ferramenta complementar ao ensino de Anatomia Humana: umrelato de extensão universitária. Revista Ciência e Extensão.2014; 10(2):47-54.

5. Talamoni ACB. Os nervos e os ossos do ofício: uma análise etnológica da aula de Anatomia.São Paulo: Editora UNESP. 2014; 978-985.

6. Castro D. A trajetória Histórica da Didática. Série Ideias n. 11. São Paulo: FDE, 1991. Disponível em:

$<$ http://www.centrorefeducacional.com.br/trajddt.htm>.

7. Tavares J. (1995). Activação do desenvolvimento psicológico nos sistemas de formação. Aveiro:CIDInE.

8. Santos MCC. A importância da atividade artesanal no desenvolvimento de alunos com perturbações intelectuais. Orientador: Cristina F. S. Pires Gonçalves. 2014. Dissertação (Mestrado em Ciências da Educação) - Escola Superior de Educação João de Deus, Lisboa, 2014. Disponível em:

https://comum.rcaap.pt/bitstream/10400.26/6191/1/Dissertação\%20MConceiçãoSan tos.pdf.

9. Xavier ALR. Et al. Manifestações clínicas e laboratoriais na infecção pelo novo coronavírus. Jornal Brasileiro de Patologia e Medicina Laboratorial. 2020. 56(1):1-9.

10. Velavan TP, Meyer CG. The COVID-19 epidemic. Medicina tropical e saúde internacional. 2020. 25(3): 278.

11. Silva EHB, Silva Neto JG, Santos MC. Pedagogia da pandemia: reflexões sobre a educação em temposde isolamento social. Revista Latino-Americana de Estudos Científicos. 2020, 29-44.

12. Freitas NK. (2006). Desenvolvimento humano, organização funcional do cérebro e aprendizagem no pensamento de Luria e de Vygotsky. Ciências \& Cognição, 9.

13. Neves MVS. Uma nova proposta no ensino de anatomia humana: desafios e novas perspectivas. Dissertação (Mestrado em Ensino em Ciências da Saúde e do Meio Ambiente) - Centro Universitário de Volta Redonda - UniFOA, Volta Redonda, 
2010.

14. Rodrigues R. Covid-19: entenda como o novo coronavírus age dentro do organismo. UNIFTC, 2020. Disponível em:https://www.uniftc.edu.br/covid-19entenda-como-o-novo-coronavirus-age-dentro-do- organismo

15. Tian S. et al. Pulmonary Pathology of Early-Phase 2019 Novel Coronavirus (COVID-19) Pneumonia in Two Patients With Lung Cancer. Journal of Thoracic Oncology, v.15, 2020.

16. Strabelli TMV, Uip DE. COVID-19 e o Coração. Arquivos Brasileiros de Cardiologia. 2020. 114(4): 598-600.

17. Albuquerque JDS et al. Aprendendo de olhos fechados: ensino da anatomia do coração e vasos da basepor meio da identificação tátil. Revista Eletrônica Acervo Saúde. 2020 (49): 3349-e3349.

18. Souza PMB et al. Metodologias ativas de ensino e aprendizagem no ensino da Anatomia Humana: Umaexperiência usando massa de modelar e outras ferramentas de comunicação em um projeto de monitoria. Brazilian Journal of Development. 2020. 6(6): 41834-41843.

19. Albuquerque JDSet al. Uso de práticas integrativas e complementares como recurso para diminuição dos níveis de ansiedade e estresse em alunos do curso de Fonoaudiologia. Brazilian Journal of Health Review. 2020. 3(5): 11461-11472.

20. Brann et al. Non-neuronal expression of SARS-CoV-2 entry genes in the olfactory system suggests mechanisms underlying COVID-19-associated anosmia. https://advances.sciencemag.org/content/6/31/eabc5801

21. Batlle D. Acute Kidney Injury in COVID-19: Emerging Evidence of a Distinct Pathophysiology. Journal of the American Society of Nephrology. 2020.

22. Freire P. Carta de Paulo Freire aos professores. Estudos avançados, 2001. 15(42): 259-268. 


\section{CAPÍTULO 05}

\section{REPERCUSSÕES DA PANDEMIA DA COVID-19 NOS PROFISSIONAIS DE SAÚDE: COMO ESTÁ QUEM ESTÁ NA LINHA DE FRENTE?}

\section{Andressa Karine Schons}

Acadêmica do curso de Bacharelado em Enfermagem Instituição: Fundação

Educacional Machado de Assis-FEMA Endereço: R. Santos Dumont, 820 - Centro,

Santa Rosa - RS

E-mail: andressaschons@outlook.com

\section{Andressa Fátima May}

Acadêmica do curso de Bacharelado em Enfermagem Instituição: Universidade Luterana do Brasil, Carazinho - ULBRA

Endereço: R. Três de Outubro, 378 - Vargas, Carazinho - RS

E-mail: andressamaypl@hotmail.com

\section{Claudia Teresinha Muller}

Acadêmica do curso de Bacharelado em Enfermagem Instituição: Fundação

Educacional Machado de Assis- FEMA

Endereço: R. Santos Dumont, 820 - Centro, Santa Rosa - RS

E-mail: claudiamuller261@gmail.com

\section{Flávia Michelle Pereira Albuquerque}

Mestre em Desenvolvimento e Políticas Públicas Instituição: Universidade Federal da Fronteira Sul - UFFS Endereço: av Francisco timm 480 - santa rosa - RS

E-mail: flaviampa@msn.com

\section{Edenilson Freitas Rodrigues}

Mestre em Desenvolvimento e Políticas Públicas Instituição: Universidade Federal da Fronteira Sul - UFFS Endereço: av Francisco timm 480 - santa rosa - RS

E-mail: edenilsonfrodrigues@gmail.com

\section{Michele Silva Lachno}

Especialista em saúde da família Instituição: Universidade Regional do Noroeste do Estado do Rio Grande do Sul Unijui Endereço: av Francisco timm 480 - santa rosa - RS

E-mail: milachno@yahoo.com.br

RESUMO: No cenário da pandemia da COVID-19, emerge enquanto protagonistas no cuidado coletivo, os trabalhadores de saúde que estão prestando à assistência direta e indireta a população. Este estudo tinha como objetivo verificar as repercussões da pandemia da COVID-19 na saúde mental, do trabalho e na física, dos profissionais de saúde da Fundação Municipal de Saúde de Santa Rosa (FUMSSAR). O estudo foi desenvolvido nas unidades de saúde da FUMSSAR. A coleta de dados foi realizada através de questionário autoaplicável, durante os meses de julho e setembro de 2020. Participaram do estudo 140 trabalhadores. Quando questionados sobre diagnósticos pré-existentes de doenças crônicas não transmissíveis (DCNT), a maioria 80 (70,4\%) 
afirmou não possuir nenhum diagnóstico prévio de DCNT. Em relação à COVID-19, a maioria - 71 (56,8\%) - dos entrevistados afirmam não se sentirem seguros, em relação ao contágio pelo novo coronavírus, em seus locais de trabalho. Apesar do medo referido e do sentimento de insegurança na atuação, 61 (48,8\%) não se afastaria do trabalho. Os resultados obtidos neste estudo auxiliam no delineamento da dimensão ocupacional durante a pandemia. Fatores como os sentimentos de medo quando da possibilidade de contaminação de familiares, transparece os elementos que constituem o sujeito para além do trabalho exercido, humanizando tais cuidadores. Espera-se que esta pesquisa auxilie na tomada de decisões em saúde voltadas para os profissionais de saúde que estão atuando na linha de frente no enfrentamento a pandemia da COVI-19.

PALAVRAS-CHAVE: Coronavírus; Sentimentos; Profissionais da saúde.

ABSTRACT: In the COVID-19 pandemic scenario, health workers who are providing direct and indirect assistance to the population emerge as protagonists in collective care. This study aimed to verify the the repercussions of the COVID-19 pandemic on the mental, work and physical health of health professionals at the Municipal Health Foundation of Santa Rosa (FUMSSAR). The study was developed in the health units of FUMSSAR. Data collection was performed through a self-administered questionnaire during the months of July and September 2020. 140 workers participated in the study. When asked about pre-existing diagnoses of chronic non-communicable diseases (NCDs), the majority 80 (70.4\%) stated that they had no previous diagnosis of NCDs. In relation to COVID-19, the majority - $71(56.8 \%)$ - of the interviewees affirm that they do not feel safe, in relation to infection by the new coronavirus, in their workplaces. Despite the referred fear and the feeling of insecurity in the performance, $61(48.8 \%)$ would not leave work. The results obtained in this study help to outline the occupational dimension during the pandemic.Factors such as feelings of fear when there is the possibility of contamination by family members, the elements that constitute the subject, in addition to the work carried out, become humanized. It is hoped that this research will assist in making health decisions aimed at health professionals who are working on the front line in coping with the COVI- 19 pandemic.

KEYWORDS: Pandemic; Feelings; Health Professionals. 


\section{INTRODUÇÃO}

O Brasil e o mundo têm atualmente a necessidade de enfrentamento aos efeitos ocorridos da COVID-19. Diversos aspectos da vida social sofreram impactos em um curto período de tempo, onde a Organização Mundial de Saúde (OMS) em março de 2020 declara pandemia, fazendo com que nações atentem para a necessidade de estratégia de minimizar os danos à saúde da coletividade.

A OMS no último dia do ano de 2019 monitorou casos de pneumonia na cidade de Wuhan na China,possivelmente relacionados a um novo tipo de coronavírus até então desconhecidos em seres humanos. Naprimeira semana de 2020, o novo vírus é identificado pelas autoridades chinesas.

Em 11 de fevereiro de 2020 o novo coronavírus recebe a denominação de SARS COV-2, sendo responsável por causar a doença COVID-19. A OMS e a OPAS trabalham em conjunto para auxiliar os países a entenderem o comportamento do vírus, como se dá a sua transmissibilidade, tratamentos e como os países tem conseguido lidar com essa pandemia.

A COVID-19 é uma doença causada pelo coronavírus SARS-CoV-2, que apresenta um quadro clínico que varia de infecções assintomáticas a quadros respiratórios graves. De acordo com a Organização Mundial de Saúde (OMS), a maioria dos pacientes com COVID-19 (cerca de 80\%) podem ser assintomáticos e cerca de $20 \%$ dos casos podem requerer atendimento hospitalar por apresentarem dificuldade respiratória e desses casos aproximadamente 5\% podem necessitar de suporte para o tratamentode insuficiência respiratória (suporte ventilatório).

Coronavírus é uma família de vírus que causam infecções respiratórias. O novo agente do coronavírus foi descoberto em 31 de dezembro de 2019 após casos registrados na China. Provoca a doençachamada de coronavírus (COVID-19).

Os primeiros coronavírus humanos foram isolados pela primeira vez em 1937. No entanto, foi em 1965 que o vírus foi descrito como coronavírus, em decorrência do perfil na microscopia, parecendo uma coroa.

A maioria das pessoas se infecta com os coronavírus comuns ao longo da vida, sendo as crianças pequenas mais propensas a se infectar com o tipo mais comum do vírus. Os coronavírus mais comuns queinfectam humanos são o alpha coronavírus 229E e NL63 e beta coronavírus OC43, HKU1. 
Os sintomas da COVID-19 podem variar de um simples resfriado até uma pneumonia severa. Sendoos sintomas mais comuns: Tosse, Febre, Coriza, Dor de garganta e Dificuldade para respirar A transmissãoacontece de uma pessoa doente para outra ou por contato próximo por meio de: Toque do aperto de mão; Gotículas de saliva; Espirro; Tosse; Catarro; Objetos ou superfícies contaminadas, como celulares, mesas, maçanetas, brinquedos, teclados de computador etc.

Neste cenário, emerge enquanto protagonistas no cuidado coletivo, os trabalhadores de saúde que estão na linha de frente prestando a assistência de maneira direta e indireta à população. Acrescido a isso cabe lembrança que o trabalhador da área da saúde tem estado exposto a um cenário amplamente dinâmico quanto orientações técnicas, garantia de insumos, equipamentos e incertezas a êxitos das condutas terapêuticas.

Os profissionais de saúde envolvidos nesse senário estão expostos diariamente ao risco de adoecer pelo coronavírus, sendo que a diferença que caracteriza este contingente da força de trabalho determina formas diferentes de exposição, tanto ao risco de contaminação quanto aos fatores associados às condiçõesde trabalho (SOUZA E SOUZA e SOUZA, 2020). Problemas como cansaço físico e estresse psicológico,insuficiência e/ou negligência com relação às medidas de proteção e cuidado à saúde desses profissionais.

Trabalhar em meio a uma pandemia exige dos profissionais e dos serviços uma estrutura consistente capaz de comandar e controlar a tomada de decisões e as informações, permitindo que estes possam atravessar a pandemia da melhor forma. Em Santa Rosa, município do noroeste do Rio Grande do Sul, nãodiferente do restante do país, há uma organização na prestação da assistência em saúde voltada à sua peculiar realidade. A Fundação Municipal de Saúde de Santa Rosa -FUMSSAR- conta com o serviço de referência em saúde do trabalhador, CEREST Fronteira Noroeste, que assiste tecnicamente a 22 municípiosda Região 14 do Rio Grande do Sul.

Com isso propõe-se um estudo que visa realizar um levantamento dos principais aspectos na vidae na saúde dos profissionais de saúde que estão na linha de frente no combate a pandemia da COVID-19, dessa maneira facilitará o desenvolvimento de atividades/treinamentos e educação continuada de modo a fornecer subsídios necessários para qualificar não só a assistência prestada como também consolidar e assegurar os profissionais diante deste senário vivenciado 
mundialmente.

\section{METODOLOGIA}

\subsection{Tipo de Estudo}

A caracterização desse estudo configura-se como uma pesquisa de abordagem tipo quantitativa, dotipo descritivo e explicativo, com delineamento transversal.

Sampieri, Colado e Baptista (2013), define a pesquisa quantitativa como a metodologia mais objetiva possível, onde se utiliza à lógica ou o raciocínio dedutivo para generalizar os resultados encontrados em um grupo maior, além disso, este tipo de abordagem permite a possibilidade de réplica doestudo ou enfoque sobre pontos específicos dos fenômenos, permitindo a comparação entre estudos similares. Além disso, para os mesmos autores, os estudos descritivos buscam identificar as propriedades ecaracterísticas de determinados grupos, processos ou fenômenos a fim de revelar com exatidão as dimensões de um fenômeno ou contexto.

O delineamento do estudo é transversal, pois os dados foram coletados em um só momento projetando um registro sobre tal situação (SAMPIERI; COLLADO; BAPTISTA, 2013).

\subsection{Unidade de Análise}

Este estudo será realizado no município de Santa Rosa/RS, que possui um quantitativo de 72.919 habitantes (IBGE, 2020), sendo um polo regional na área da saúde nos diferentes níveis de atenção, contemplando desde ações preventivas e diferenciais na $A B$ até serviços e ações na área da alta complexidade (FUMSSAR, 2016).

O estudo foi desenvolvido nas unidades de saúde da FUMSSAR, que possui 434 (quatrocentos e trinta e quatro) funcionários trabalhando na linha de frente de combate a pandemia. Atualmente aFUMSSAR conta com 18 (dezoito) Unidades Básicas de Saúde e três unidades sentinelas, além de, dois CAPS, um CER II e um CEREST. Foram sujeitos do estudo, trabalhadores da área da saúde, na atenção básica, que estavam atuando na linha de frente da pandemia de COVID-19, no 
momento da coleta de dados, que estivessem atuando em estabelecimentos de saúde credenciados junto ao Cadastro Nacional deEstabelecimentos de Saúde (CNES).

Responderam ao questionário 140 trabalhadores da área da saúde que estão atuando na linha de frente da pandemia de COVID-19 do setor público de saúde do município em unidades básicas de saúde e unidades sentinela.

\subsection{Sujeitos da pesquisa}

O estudo realizou-se com cento e quarenta profissionais da área da saúde do município de Santa Rosa/RS, que estão atuando em estabelecimentos de saúde credenciados junto ao Cadastro Nacional de Estabelecimentos de Saúde (CNES) e que estão atuando na linha de frente da COVID-19 no ano de 2020.

\subsection{Coleta de dados}

O instrumento de coleta de dados foi submetido a um pré-teste com participantes semelhante ao grupo estudado, participando três enfermeiros, 01 técnico de enfermagem, 01 fonoaudióloga e 01 médica. Estes foram escolhidos no município de Santa Rosa, com equipes de saúde semelhantes. Com o pré-teste do instrumento foi possível avaliar a compreensão das questões, assim como realizar as alterações necessárias previamente à etapa de coleta de dados.

A coleta de dados efetivou-se através do google forms, contendo trinta e cinco questões de múltiplaescolha no período de julho a setembro de 2020. O questionário contem questões acerca do perfil Sociodemográfico dos participantes, descrição da atuação profissional e aspectos relacionados ao COVID-19.

\subsection{Análise e interpretação dos dados}

As variáveis categóricas serão apresentadas em percentuais. Para avaliar as diferenças nas variáveiscategóricas. Foi utilizado o teste de qui-quadrado. Para todas as análises, foi considerado um nível de significância de 5\%. A análise estatística foi realizada com auxílio só software SPSS versão 22.0. 
A pesquisa respeitou a Resolução CNS no466/2012 do Conselho Nacional de Saúde do Ministério da Saúde, como também o Código de Ética Profissional dos Psicólogos. Considerar-se-á os seguintes aspectos éticos: Aprovação pelo Comitê Científico do Núcleo de Ensino e Pesquisa (NEP) da Fundação Municipal de Saúde de Santa Rosa. Parecer Consubstanciado do Comitê de Ética em Pesquisa (CEP) aprovado sob o no 4.233.095 e CAAE 33172920.6.0000.5331. Termo de Consentimento Livre e Esclarecido(TCLE).

\section{RESULTADOS}

Nesta pesquisa responderam ao questionário 140 profissionais da área da saúde, que estão na linhade frente, com idade entre 18 a 60 anos ou mais, sendo que $29,28 \%$ tinham entre 18 e 29 anos, desvelando equipe muito jovem. Quanto aos gêneros das equipes $08,57 \%$ pessoas são do sexo masculino e $91,42 \%$ pessoas do sexo feminino. De modo similar o gênero associa-se à elaboração cultural, então os gêneros masculino e feminino são construções culturais, sendo capaz de ter oscilações no tempo e no espaço que estão em constantes formações, por conseguinte o sexo relaciona-se ao biológico (RAVAGANI, 2007).

Ao considerar a finalidade de compreender as reações e os sentimentos de profissionais da linha de frente, no atendimento a pacientes com suspeita e/ou confirmados de COVID-19, foram entrevistados os profissionais que trabalham na FUMMSAR, setor público municipal. Desta amostra 37,14\% declaram estado civil solteiro (a) e $36,42 \%$ casados tendo em vista que grande parte das pessoas participantes tem ensino médio e técnico $(47,14 \%)$, do mesmo modo que possuem graduados $(18,57 \%)$ e especialistas $(29,28 \%)$ na área de atuação. Já em relação ao tempo de trabalho dos profissionais entrevistados na instituição do estudo, 10,71\% referiram trabalhar entre zero a seis meses; $13,57 \%$ entre dose meses a vintee quatro meses; mais de quarenta e oito meses cerca de $60,71 \%$. 
Tabela 1: Perfil Sociodemográfico

\begin{tabular}{|c|c|}
\hline Variáveis & Percentual dosusuários ( $\mathrm{N}=140$ ) n\% \\
\hline \multicolumn{2}{|l|}{ Sexo } \\
\hline Masculino & $08,57 \%$ \\
\hline Feminino & $91,42 \%$ \\
\hline \multicolumn{2}{|l|}{ Grau de instrução } \\
\hline Ensino Médio e Técnico & $47,14 \%$ \\
\hline Ensino Superior & $18,57 \%$ \\
\hline Especialização & $29,28 \%$ \\
\hline Mestrado & $04,28 \%$ \\
\hline Doutorado & $00,71 \%$ \\
\hline \multicolumn{2}{|l|}{ Estado Civil } \\
\hline Casado & $36,42 \%$ \\
\hline Solteiro & $37,14 \%$ \\
\hline União estável & $17,14 \%$ \\
\hline Separado ou divorciado & $06,42 \%$ \\
\hline Viúvo (a) & $02,85 \%$ \\
\hline \multicolumn{2}{|l|}{ Idade } \\
\hline De 18 a 29 anos & $29,28 \%$ \\
\hline De 30 a 39 anos & $27,85 \%$ \\
\hline De 40 a 49 anos & $22,85 \%$ \\
\hline De 50 a 59 anos & $18,57 \%$ \\
\hline De 60 anos ou mais & $01,42 \%$ \\
\hline
\end{tabular}

Fonte: Os autores

Tabela 2: Perfil profissional dos profissionais da saúde

\begin{tabular}{|l|c|}
\hline Variáveis & Percentual dosusuários (N=140) n\% \\
\hline Você é profissional da saúde? & \\
\hline Não & $98,57 \%$ \\
\hline Em que área atua? & $01,42 \%$ \\
\hline Agente Comunitário em Saúde & \\
Odontologia & \\
Auxiliar de Saúde Bucal & $19,28 \%$ \\
\hline Técnico em Enfermagem & $07,14 \%$ \\
Enfermagem & $00,71 \%$ \\
Medicina & $20,71 \%$ \\
Farmácia & $18,57 \%$ \\
Técnico em Farmácia & $05,00 \%$ \\
Psicologia & $05,71 \%$ \\
Fonoaudiologia & $01,42 \%$ \\
Educação Física & $05,71 \%$ \\
Nutrição & $03,57 \%$ \\
Terapia Ocupacional & $00,71 \%$ \\
Médico Veterinario & $00,71 \%$ \\
Administração & $00,71 \%$ \\
\hline
\end{tabular}




\begin{tabular}{|c|c|}
\hline $\begin{array}{l}\text { Agente Administrativo } \\
\text { Estagiário } \\
\text { Não responderam }\end{array}$ & $\begin{array}{l}00,71 \% \\
00,71 \% \\
00,71 \%\end{array}$ \\
\hline Em que setor atua? & \\
\hline $\begin{array}{l}\text { Público } \\
\text { Outro }\end{array}$ & $\begin{array}{c}100,00 \% \\
00,00 \%\end{array}$ \\
\hline $\begin{array}{l}\text { Tempo de atuação na área } \\
\text { Mais de } 48 \text { meses } \\
24 \text { a } 48 \text { meses } \\
12 \text { a } 24 \text { meses } \\
6 \text { a } 12 \text { meses } \\
0 \text { a } 6 \text { meses }\end{array}$ & $\begin{array}{l}60,71 \% \\
07,85 \% \\
13,57 \% \\
07,14 \% \\
10,71 \%\end{array}$ \\
\hline $\begin{array}{l}\text { Possui diagnóstico de doença (s) pre-existente } \\
\text { (s)? } \\
\text { Não possuo } \\
\text { Doença cardiovascular (HAS, cardiopatia...) } \\
\text { Doença respiratória (asma, bronquite...) } \\
\text { Doença endócrina (diabetes, hipotireoidismo...) } \\
\text { Obesidade } \\
\text { Fibromialgia } \\
\text { Ansiedade } \\
\text { Trombose } \\
\text { Imunossupressão } \\
\text { Epilepsia } \\
\text { Doença autoimune } \\
\text { Tinha câncer }\end{array}$ & $\begin{array}{l}72,14 \% \\
09,28 \% \\
07,14 \% \\
05,71 \% \\
00,71 \% \\
00,71 \% \\
00,71 \% \\
00,71 \% \\
00,71 \% \\
00,71 \% \\
00,71 \% \\
00,71 \% \\
00,71 \%\end{array}$ \\
\hline $\begin{array}{l}\text { Faz uso de medicamentos contínuos? } \\
\text { Sim } \\
\text { Não }\end{array}$ & $\begin{array}{l}40,00 \% \\
60,00 \%\end{array}$ \\
\hline $\begin{array}{l}\text { Senti medo relacionado à Pandemia de COVID- } \\
19 ? \\
\text { Razoavelmente } \\
\text { Muito } \\
\text { Pouco ou nenhuma }\end{array}$ & $\begin{array}{l}50,00 \% \\
32,14 \% \\
17,85 \%\end{array}$ \\
\hline $\begin{array}{l}\text { Com a chegada da COVID 19, tem feito uso de } \\
\text { alguma substância lícita ou ilícita (álcool, } \\
\text { tabaco, maconha, cocaína) } \\
\text { Sim } \\
\text { Não }\end{array}$ & $\begin{array}{l}21,42 \% \\
78,57 \%\end{array}$ \\
\hline
\end{tabular}

Fonte: Os autores

Tabela 3: Sentimentos vivenciados pelos profissionais de saúde frente à pandemia Tive alterações no SONO (insônia, sonhos pertubadores, dificuldades para adormecer...)

Nenhum dia 


\begin{tabular}{|c|c|}
\hline $\begin{array}{l}\text { Em } 1 \text { a } 2 \text { dias na semana } \\
\text { Em } 3 \text { a } 4 \text { dias na semana } \\
\text { Em } 5 \text { a } 6 \text { dias na semana } \\
\text { Todos os dias }\end{array}$ & $\begin{array}{l}36,42 \% \\
34,28 \% \\
18,57 \% \\
02,85 \% \\
05,00 \% \\
\end{array}$ \\
\hline $\begin{array}{l}\text { Senti-me ansioso (a), agitado (a), inquieto (a) } \\
\text { desde o início da pandemia: } \\
0 \\
1 \\
2 \\
3 \\
4 \\
5 \\
\end{array}$ & $\begin{array}{l}05,71 \% \\
11,42 \% \\
20,00 \% \\
24,28 \% \\
19,28 \% \\
19,28 \% \\
\end{array}$ \\
\hline \begin{tabular}{|l|l|} 
Senti-me TRISTE \\
0 \\
1 \\
2 \\
3 \\
4 \\
5 \\
\end{tabular} & $\begin{array}{l}12,14 \% \\
12,85 \% \\
23,57 \% \\
17,85 \% \\
17,85 \% \\
15,71 \% \\
\end{array}$ \\
\hline \begin{tabular}{|l} 
Senti-me MOTIVADO (A) ENTUSIASMADO (A) \\
0 \\
1 \\
2 \\
3 \\
4 \\
5
\end{tabular} & $\begin{array}{l}17,14 \% \\
23,57 \% \\
22,14 \% \\
20,71 \% \\
09,28 \% \\
07,14 \%\end{array}$ \\
\hline \begin{tabular}{|l|l|} 
Senti meu coração acelerado mesmo não tendo \\
feito esforço físico \\
0 \\
1 \\
2 \\
3 \\
4 \\
5 \\
\end{tabular} & $\begin{array}{l} \\
26,42 \% \\
12,85 \% \\
12,14 \% \\
19,28 \% \\
17,85 \% \\
11,42 \% \\
\end{array}$ \\
\hline $\begin{array}{l}\text { Tive suores, mal-estar? } \\
\text { Eventualmente } \\
\text { Todos os dias } \\
\text { Não tenho/tinha atividades }\end{array}$ & $\begin{array}{l}57,14 \% \\
05,00 \% \\
05,00 \%\end{array}$ \\
\hline
\end{tabular}

Fonte: Os autores

Tabela 4: Segurança e capacitação no trabalho durante a pandemia da COVID-19 Tenho a possibilidade de falar com alguém sobre meus problemas no trabalho ou em casa$$
\begin{aligned}
& 0 \\
& 1 \\
& 2 \\
& 3 \\
& 4
\end{aligned}
$$ 


\begin{tabular}{|c|c|}
\hline 5 & $\begin{array}{l}23,57 \% \\
17,14 \%\end{array}$ \\
\hline $\begin{array}{l}\text { Sente-se seguro (a) em seu local de trabalho? } \\
\text { Sim } \\
\text { Não }\end{array}$ & $\begin{array}{l}45,00 \% \\
55,00 \% \\
\end{array}$ \\
\hline $\begin{array}{l}\text { Você se afastaria do seu local de trabalho nesse } \\
\text { período? Se sim, por qual dos motivos: } \\
\text { Me afastaria por medo de me contaminar } \\
\text { Não me afastaria } \\
\text { Doença autoimune } \\
\text { Me afastaria por me sentir inseguro no local de } \\
\text { trabalho (falta de EPI'S) } \\
\text { Me afastaria para proteger os meus familiares } \\
\text { Já estou afastado por motivos de saúde } \\
\text { Se necessário independente do caso } \\
\text { Se tiver doente com sintomas } \\
\text { Férias }\end{array}$ & $\begin{array}{r}12,14 \% \\
51,42 \% \\
00,71 \% \\
01,42 \% \\
\\
24,71 \% \\
\\
04,28 \% \\
00,71 \% \\
00,71 \% \\
01,42 \% \\
\end{array}$ \\
\hline $\begin{array}{l}\text { Você se sente sobrecarregado (a)? } \\
\text { Sim } \\
\text { Não } \\
\text { Consideravelmente } \\
\end{array}$ & $\begin{array}{l}48,57 \% \\
28,57 \% \\
22,85 \% \\
\end{array}$ \\
\hline $\begin{array}{l}\text { O quanto você se sente capacitado (a) } \\
\text { tecnicamente para atuar no enfrentamento e } \\
\text { controle da COVID-19? } \\
\text { Pouco capacitado (a) } \\
\text { Mais ou menos capacitado (a) } \\
\text { Nada capacitado (a) } \\
\text { Muito capacitado (a) }\end{array}$ & $\begin{array}{l}25,00 \% \\
57,85 \% \\
08,57 \% \\
08,57 \%\end{array}$ \\
\hline
\end{tabular}

Fonte: Os autores

\section{DISCUSSÃO}

O município de Santa Rosa está localizado no noroeste do estado do Rio Grande do Sul, com uma área territorial de 488,4 quilômetros quadrados, com economia predominante metal mecânico e agrícola, sendo também conhecida como Berço Nacional da Soja. A região é modelo do segmento industrial no setorpolo metal mecânico, fabricando peças, máquinas e implementos agrícolas, movimentando o agronegócioe produzindo 66\% das colheitadeiras brasileiras (PMSR, 2016).

A necessidade de inovação para melhor eficácia na gestão municipal da saúde com base na busca da universalidade do acesso, ações e serviços e na democratização das relações com a sociedade, impulsionou a implantação do Sistema 
Único de Saúde no município de Santa Rosa. Houve priorização dapolítica de saúde aos princípios do SUS em 1993, passando a ser um dos dois primeiros municípios no Estado do Rio Grande do Sul a efetivar a municipalização (GALLO, 2007).

Em meados da década de 90 emerge, no cenário brasileiro, a proposição de reorganização do modeloassistencial de saúde e a partir desta proposta criada, em 1994, o Programa de Saúde da Família (PSF) que, na década seguinte, reorganiza-se em Estratégia de Saúde da Família (ESF). A ESF é a porta de entradapara a população no Sistema Único de Saúde (SUS), representando um mecanismo emblemático dereorganização da Atenção Primária em Saúde (APS) em nosso país (BRASIL, 2012). Em sua forma maisdesenvolvida, a APS é o primeiro contato com o sistema de saúde e o local responsável pela organizaçãodo cuidado à saúde dos indivíduos, suas famílias e da população ao longo do tempo (STARFIELD, 2002).

A partir das considerações feitas acima e com o princípio da descentralização a Fundação Municipal de Saúde assume a total responsabilidade pelas ações e estratégias de ampliação da política pública de saúdeem seu território tendo como foco principal a APS. A APS possui diversos mecanismos e capilaridades a fim de atender as demandas peculiares dos sujeitos e do local em que vivem, resultando nas diferentes ofertas e ações de serviços. Para isso o Ministério da Saúde propõe diversas áreas de atuações a fim de atender esses cenários plurais, tais como: serviços na área de saúde mental como Centros de Atenção Psicossocial (CAPS), equipes de apoio nos territórios dos ESF Núcleo de Apoio à Saúde da Família (NASF), academias populares de saúde, serviços especializados entre outros.

O Centro de Referência em Saúde do Trabalhador - CEREST está sediado no município de Santa Rosa - RS, tendo sua abrangência na região Fronteira Noroeste, contemplando um total de 22 (vinte e dois)municípios da 14ํㅜㄹegião de Saúde do Rio Grande do Sul.

Conforme Portaria do Ministério da Saúde no 2.728/2009 que dispõe sobre a Rede Nacional de Atenção Integral à Saúde do Trabalhador (RENAST) e dá outras providências, os Centros de Referência em Saúde do Trabalhador - CEREST tem por função dar subsídio técnico para o SUS, nas ações de promoção, prevenção, vigilância, diagnóstico, tratamento e reabilitação em saúde dos trabalhadoresurbanos e rurais.

No contexto do SUS a área de Saúde do Trabalhador emerge como um desafio 
a mais, no sentidode promover os meios necessários para atendimento com primazia, o que a partir de 1988 com aConstituição Federal, passou a ser também, atribuição das Secretarias de Saúde dos Estados e Municípios. O CEREST - Fronteira Noroeste em Santa Rosa é composto pelos seguintes profissionais na área técnica: Enfermeira, Fisioterapeuta, Fonoaudióloga, Técnica em Enfermagem, Técnico em Segurança do Trabalho, Médica e Psicóloga.

É neste contexto que esta pesquisa está inserida, tendo na linha de frente no combate ao COVID- 19 , os profissionais técnicos em enfermagem $(20,71 \%)$, enfermeiros (18,57\%), agentes comunitários de saúde (19,28\%) odontólogos $(07,14 \%)$, psicólogos (05,71\%) médicos (05,00\%) e demais capacitados, realizam os atendimentos a população nos estabelecimentos de saúde e nos domicílios, adotando os protocolos de controle de infecção (contato, via aérea) EPIs, incluindo máscaras N95, aventais, óculos, protetores faciais e luvas permitindo a segurança do profissional e do paciente. Sendo que $100 \%$ dos entrevistados são profissionais de saúde que atuam no Sistema Único de Saúde (SUS) e destes, 60\% têm mais de dois anos de atuação, no momento da pesquisa, no SUS.

No entanto, conforme Duarte, Silva e Bagatini (2021), sabe-se que, diante do cenário atual, há escassez de EPIs em vista disso orienta-se o uso de máscaras faciais de tecido para a população em geral, já que as descartáveis precisam ser destinadas a estes profissionais. Além disso, a falta desses equipamentostambém é fonte geradora de medo e angústia para equipe.

A exposição dos profissionais de saúde no cuidado direto a paciente com o vírus tem influência nasua saúde mental, impactando nos processos de trabalho e na vida pessoal desses trabalhadores (DUARTE, SILVA e GABATINI, 2021). Nesse sentido, essa pesquisa mostra um número expressivo desses profissionais que relataram apresentar sintomas relacionados a alterações com o sono (insônia, sonhos perturbadores, dificuldade para adormecer...) responderam; nenhum dia (36,42\%), em um a dois dias na semana (34,28\%) em três a quatro dias na semana $(18,57 \%)$ e todos os dias $05,00 \%$, ao mesmo tempo esses profissionais relataram sentirem-se ansioso/agitado $(19,28 \%)$; triste $(23,57 \%)$. Esses sintomas provavelmente possuem relação com o estigma de os profissionais por terem contato direto com os pacientes contaminados, assim como maior demanda no ambiente de trabalho, e a necessidade de atualização constante $(\mathrm{CH}, 2020)$. 
Já quando questionados sobre, o sentimento de medo relacionado à pandemia, $50 \%$ responderam razoável, muito $32,14 \%$ e $17,85 \%$ relataram pouco ou nenhum. Esses mistos de sentimentos são uma reaçãonatural diante de uma ameaça real e proeminente, que demanda muitas vezes um agir racional para seu enfrentamento, pautado em informações realistas e concretas, com a finalidade de contribuir, assim para asmedidas de proteção acessíveis (JODELET, 2019).

Por conta disso, o cenário desolador pode provocar quadros de burnout (estresse relacionado ao trabalho), que é compreendido por Silva et. al (2015), como um esgotamento profissional causado por umasíndrome psicológica decorrente da tensão emocional crônica vivida pelo trabalhador, associada a despersonalização e baixa realização pessoal. Tendo em vista que $48,57 \%$ dos entrevistados sentem-se sobrecarregados profissionalmente, e não se sentem seguros no campo de trabalho (55,00\%) em função do aumento de risco no adoecimento ou por contaminação, oferecendo insegurança para realizar procedimentos, mas ao mesmo tempo não deixariam de realizar a assistência à população $(51,42 \%)$. Este estado de tensão emocional e estresse crônico, provocado por condições de trabalho físicas, emocionais e psicológicas desgastantes faz com que, pessoas cuja profissão exige envolvimento interpessoal direto e intenso, adoeçam. Profissionais das áreas de educação, saúde, assistência social, recursos humanos, agentes penitenciários, bombeiros, policiais e mulheres que enfrentam dupla jornada correm risco maior de desenvolver a síndrome de burnout.

Burnout na saúde é um fenômeno complexo e multidimensional resultante da interação entre aspectos individuais e o ambiente de trabalho, a ocorrência em profissionais da saúde tem sido consideradaum fenômeno psicossocial relevante, pois afeta não somente o profissional, mas também o ambiente de trabalho, interferindo na obtenção dos objetivos terapêuticos, uma vez que os profissionais acometidos pela síndrome desenvolvem um processo de alienação, desumanização e apatia. Burnout é o resultado do estresse crônico, típico do cotidiano do trabalho, principalmente quando neste existem excessiva pressão, conflitos, poucas recompensas emocionais e pouco reconhecimento, sendo considerado um fenômeno psicossocial constituído de três dimensões: Exaustão Emocional, Despersonalização e Baixa Realização Profissional. O "Esgotamento Emocional" caracteriza-se pela sensação de exaustão emocional e física, naqual o sujeito constata que não possui energias suficientes para 
continuar a trabalhar; A "Despersonalização" representa a dimensão do contexto interpessoal do burnout e refere-se a atitudes de distanciamento emocional direcionadas às pessoas a quem o sujeito deve prestar serviços, bem como aos colegas de trabalho; E a "Falta de Realização" corresponde à dimensão da autoavaliação do burnout e, tal como o nome indica, refere-se a sentimentos de incompetência e de baixa produtividade no trabalho, bem como de descontentamento a nível pessoal.

O sintoma típico da síndrome de burnout é a sensação de esgotamento físico e emocional que se reflete em atitudes negativas, como ausências no trabalho, agressividade, isolamento, mudanças bruscas dehumor, irritabilidade, dificuldade de concentração, lapsos de memória, ansiedade, depressão, pessimismo, baixa autoestima. Além disso, pode haver a presença de dor de cabeça, enxaqueca, cansaço, sudorese, palpitação, pressão alta, dores musculares, insônia, crises de asma, distúrbios gastrintestinais são manifestações físicas que podem estar associadas à síndrome, sinais e sintomas estes referidos pelos profissionais de saúde na pesquisa realizada. O tratamento da Síndrome de Bournout inclui o uso de antidepressivos e psicoterapia. Atividade física regular e exercícios de relaxamento também ajudam a controlar os sintomas, melhorando a qualidade de vida.

É necessário avaliar se é o ambiente profissional que causa o estresse ou se são as atitudes da própriapessoa que passam a ser o estopim. Existem três focos durante o tratamento psicoterápico: a relação com aprofissão, o ambiente de trabalho e o trabalho com foco nos sintomas - por exemplo, a dificuldade de concentração. Junto à terapia, os especialistas aconselham melhorar a qualidade de vida, prevenir o estresse, garantir boa saúde física, dormir e alimentar-se bem, praticar atividades físicas e manter hobbies e interessepela vida social. Especialistas orientam não usar a falta de tempo como desculpa para não praticar exercíciosfísicos e não desfrutar momentos de descontração e lazer. Quanto à realização de atividades de lazer durante a pandemia, os profissionais de saúde entrevistados referiram realizar eventualmente $(57,14 \%)$ e não realizar (32,85\%). Desta forma, é urgente mudanças no estilo de vida para prevenir ou tratar a síndrome deburnout, além de avaliar a possibilidade de propor novas dinâmicas para as atividades diárias e objetivos profissionais, devendo ter este foco os serviços de saúde que pretendem realizar o enfrentamento a síndrome de burnout em seus trabalhadores. 
Em relação à segurança e saúde dos profissionais de saúde, amplamente discutido em diversas publicações, ressalta-se que uma força de trabalho capacitada e motivada esta diretamente relacionada aosinvestimentos realizados na promoção da saúde e segurança do trabalhador (SILVA-JUNIOR, 2017). Nestesentido, as respostas dos trabalhadores de saúde questionados quanto se sentirem seguros no local de trabalho, refletem na boa gestão e condução de recursos financeiros e pessoais investidos no município.

Posto isto, consideramos a relação de segurança dos trabalhadores com seu ambiente de trabalho pode estar relacionada à estabilidade no serviço de saúde, ao plano de carreiras dos servidores municipais e vínculos formais de trabalho.

Salientando a realidade local, vários projetos e ações de saúde ocupacional surgem a fim de minimizar as mudanças na rotina de trabalho durante a pandemia e contribuir para a manutenção da saúdedo profissional que está na linha de frente. Destacamos as ações desenvolvidas pela instituição FUMSSAR, juntamente do CEREST Fronteira Noroeste e o Núcleo de Ensino e Pesquisa (NEP), no âmbito de educação em saúde e condições de trabalho visam reduzir os impactos na rede de assistência e na saúde de seus trabalhadores, preparando o sistema e servidores frente à nova situação.

Barroso et al. (2020) ressaltam a necessidade de ações e reflexões acerca dos processos de trabalho, interlocução entre gestores e servidores, capacitações e treinamentos constantes dos trabalhadores.

Conforme Almeida (2020), os desafios emergentes a nova situação manifestada em várias localidades podem estar relacionados ao escasso tempo de preparo e a necessidade de implementação imediata de ações efetivas no controle da COVID-19, associada as dificuldades e carências que o serviço de saúde já apresentava.

Frente essa necessidade de reestruturação e resposta rápida e eficaz para controle da pandemia, destacamos a criação do Comitê Intersetorial de Enfrentamento a COVID-19, a organização de unidades sentinelas em 3 regiões do município para atendimento de indivíduos com sintomas respiratórios, e pactuada rede intersetorial com vistas a garantir e organizar o fluxo dos pacientes com síndrome respiratória, contando com a implantação do serviço hospitalar de unidade Especializada de tratamento a COVID-19 e o serviço da Unidade de Pronto Atendimento (UPA), ambos 
como referência de internação, alguns deles a nível regional.

Enfatizando os dados obtidos no que se refere à sensação de segurança no local de trabalho pelos profissionais de saúde, o sistema se sobressai nas ações realizadas no enfrentamento a COVID-19 ao disporde uma rede de serviços locais, disponibilidade de equipamentos e recursos humanos. Tais medidas, adotadas também por outros estados brasileiros, têm reconhecido o trabalhador do SUS como linha de frente imprescindível no combate à pandemia.

Corroborando com o que vem sendo realizado no âmbito local, Barroso et al. (2020), substância anecessidade de medidas de proteção, capacitação e oferta de condições de trabalho adequadas para os profissionais dos estabelecimentos de saúde, sobretudo, maior destinação de recursos a tais medidas, contratação de maior número de profissionais.

Em diferentes localidades do país e do mundo, muitos profissionais da área da saúde estão atuandodiretamente na linha de frente desde o início da pandemia. Com isso, além da disseminação sem precedentesdo vírus e a capacidade do sistema de saúde em dar conta de tal situação, em muito se faz necessário a realavaliação de como esses profissionais se encontram no exercício de suas respectivas funções. A ansiedadenos profissionais de saúde durante a pandemia pela Covid-19

As condições de trabalho de diferentes profissionais dentre médicos, enfermeiros, técnicos em enfermagem entre outros, a médio e longo prazo se torna um desafio, principalmente em relação há quantotempo permanecerão ativos para o bom desempenho de suas atividades. Além disso, faz repensar que alémdas aflições percebidas pela maioria das pessoas, estes "heróis sem capa" sofrem por turnos de trabalho extensos, maior risco de exposição ao vírus, mudanças em seus respectivos ambientes laborais, além das questões morais que envolvem diretamente seus familiares e a insegurança caso se contaminem e por consequência acabam por contaminar algum ente querido. A ansiedade nos profissionais de saúde durantea pandemia pela Covid-19

Estes diferentes cenários vivenciados diariamente pelos profissionais de saúde atuantes da linha defrente: efetivos de trabalhadores reduzidos por comporem grupos de risco, sobrecarga de trabalho aos demais atuantes, jornadas prolongadas de trabalho, além dos citados anteriormente, apenas reforçam o quanto este cenário degradante aumenta as chances de sofrimento mental, sobrecarga física, gerando 
frustrações e ansiedades sem precedentes para esses trabalhadores (ALMEIDA, 2020).

Quando relatado a saúde mental, além das questões vividas diretamente pelos profissionais, o método repercutido de distanciamento social, também impacta diretamente a população, principalmente noque diz respeito às relações interpessoais totalmente modificadas e muitas vezes prejudicadas nesse períodode pandemia.

Neste cenário preocupante em relação à saúde mental dos trabalhadores o que se salienta é a importância do Estado em voltar às atenções para esta realidade, sendo que muitos dos danos ocasionadospelo período pandêmico serão notados após o seu término. Para isso, a dedicação de esforços individuais ecoletivos nas diferentes áreas do conhecimento, poderão reduzir os impactos negativos na saúde mental desses profissionais.

Ademais, os profissionais da saúde quando questionados sobre o "quanto se sente capacitado (a) tecnicamente para atuar no enfrentamento e controle da COVID19”, 25\% responderam que se sentem pouco capacitado (a), 57,85\% mais ou menos capacitados (as), 08,57\% nada capacitado (a) e 08,57\% sentem-se muito capacitados (as). O Ministério da Saúde lançou no início de abril de 2020 a ação estratégica“Brasil conta comigo - Profissionais da Saúde", que teve como objetivo o cadastro e capacitação de profissionais que estivessem dispostos a atuar no combate ao COVID19 no país, ficando à disposição de gestores federais, estaduais, distritais e municipais do SUS (SOUZA E SOUZA e SOUZA, 2020).

\section{CONCLUSÕES OU CONSIDERAÇÕES FINAIS}

Os resultados obtidos neste trabalho auxiliam no delineamento da dimensão ocupacional emprofissionais da saúde durante a pandemia. Fatores como os sentimentos de medo quando da possibilidadede contaminação de familiares, transparece os elementos que constituem o sujeito para além do trabalho exercido, humanizando tais cuidadores. Cabe aqui que ressaltar que as dimensões de planejamento e de gestão em saúde considerem as peculiaridades em que os trabalhadores se encontram neste momento.

Os achados até aqui também reforçam o que a literatura científica, normas e legislações da saúde do trabalhador afirmam da importância de proporcionar um 
ambiente de trabalho seguro faz-se necessário. Em especial neste período de pandemia, as garantias de um ambiente seguro para profissionais de saúde.

Os resultados obtidos neste trabalho auxiliam no delineamento da dimensão ocupacional emprofissionais da saúde durante a pandemia. Fatores como os sentimentos de medo quando da possibilidade de contaminação de familiares, transparece os elementos que constituem o sujeito para além do trabalho exercido, humanizando tais cuidadores. Cabe aqui que ressaltar que as dimensões de planejamento e de gestão em saúde considerem as peculiaridades em que os trabalhadores se encontram neste momento.

Os achados até aqui também reforçam o que a literatura científica, normas e legislações da saúde do trabalhador afirmam da importância de proporcionar um ambiente de trabalho seguro faz-se necessário. Em especial neste período de pandemia, as garantias de um ambiente seguro para profissionais de saúde.

Compreende-se dessa maneira, que a pandemia o qual estamos vivenciando é multidimensional,com impactos em todas as dimensões, incluindo físico, emocional, econômico, social e psicológico. Sendoassim, embora o medo e a ansiedade sejam esperados durante esse período, também é importanteentendermos e identificarmos de maneira precoce para darmos respostas adequadas a tais sinais e sintomas.

Pensando nisso, acreditamos que a prevenção, promoção em saúde e ações de educação em saúde são ideias nesse momento, com a presença e o amparo de psicólogos, psicoterapeutas e psiquiatras nos centros hospitalares e nas Unidades de atendimentos com a finalidade de prestarem uma assistência/suporteaos profissionais. Desse modo, em síntese é fundamental que os especialistas precisam dispor de formaçõesespecíficas para lidar com o tipo de demanda, sabendo manejar os casos corretamente e lidando com as necessidades de saúde mental dos profissionais de saúde.

Consideramos importante, o reconhecimento e a valorização/enaltecimento aos profissionais envolvidos no combate a pandemia da Covid-19, visando a sua importância nesse momento tão delicado que a sociedade vive, pois muitos estão realizando horas extras de trabalho, consumindo energias acima do normal e ao mesmo tempo acabam deixando de gozar das atividades em lazer com suas famílias com o propósito de não os expor.

Diante o cenário pandêmico o qual enfrentamos, é possível salientar e 
manifestar o quão importanteé o apoio dos cidadãos aos profissionais de saúde que estão na linha de frente prestando a assistência de maneira direta e indireta à população em condições que nem sempre são seguras. Isso tudo, contribui parao reconhecimento do protagonismo dos profissionais de saúde pública como ordenadora do cuidado no SUS.

Espera-se que esta pesquisa auxilie na tomada de decisões em saúde do trabalhador de saúde, visando melhorias na qualidade e segurança do trabalho, que proporcionará qualidade de vida e promoçãoda saúde aos profissionais que atuam na linha de frente a pandemia da COVID-19. 


\section{REFERÊNCIAS}

ALMEIDA, I.M. de. Proteção da saúde dos trabalhadores da saúde em tempos de COVID-19 e respostas àpandemia. Rev. bras. saúde ocup., São Paulo, v.45, n.17, 2020.

BARROSO, B.I.L.; SOUZA, M.B.C.A.; BREGALDA, M.M.; LANCMAN, S.; COSTA, V.B.B. Saúde do trabalhador em tempos de covid-19: reflexões sobre saúde, segurança e terapia ocupacional. Rev. bras.saúde ocup., São Paulo, no prelo, 2020.

BRASIL. Ministério da Saúde. Política Nacional de Atenção Básica (PNAB). Brasília: Ministério daSaúde, 2012.

DUARTE, Maria de Lourdes Custódio; SILVA, Daniela Giotti da; BAGATINI, Mariana Mattia Correa. Enfermagem e saúde mental: uma reflexão em meio à pandemia de coronavírus.

Rev. Gaúcha Enferm. Vol.42, Porto Alegre, 2021.

FUNDAÇÃO MUNICIPAL DE SAÚDE DE SANTA ROSA - FUMSSAR. Plano Municipal de Saúde do Município de Santa Rosa 2016-2019. Santa Rosa: FUMSSAR, 2016.

GALLO, Z.M.C. A ética discursiva dos atores da política de saúde de Santa Rosa. 2007, 143f. Tese (Doutorado em Serviço Social) - Pontifícia Universidade Católica do Rio Grande do Sul, Porto Alegre, 2007.

IBGE - INSTITUTO BRASILEIRO DE GEOGRAFIA E ESTATISTICA. Rio de Janeiro: 2020. Disponivel em: http://cidades.ibge.gov.br/xtras/perfil.php?lang=\&codmun $=431720 \&$ search $=\| i$ nfogr\%E1ficos:-informa\%E7\%F5es-completas Acesso em: maio.2020.

CH - INTER-AGENCY STANDING COMMITTEE IASC's Reference Group on Mental Health andPsychosocial Support. Interim briefing note addressing mental health and psychosocial aspects of COVID - 19 outbreak. Geneva: IASC; 2020 [cited 2020 Apr 15]. Avai lable from:https://interagencystandingcommittee.org/iasc-reference-group-mental-healthand-psychosocial-support- emergency-settings/interim-briefing-note-addressing-mentalhealth-and-psychosocial-aspects-covid-19- outbreak

JODELET, Denise. Abordagem psicossociológica sobre ameaças e seus usos sociais, [s. I.], 2019.Disponível em: https://www.scielo.br/j/se/a/9RKx5XjMDb98qHWfDrnD $\mathrm{VxQ} /$ ?lang=pt

PREFEITURA MUNICIPAL DE SANTA ROSA- PMSR. Santa Rosa: 2016. Disponível em: http://www.santarosa.rs.gov.br/index2.php Acesso em: maio. 2020.

RAVAGNI E. O que é Sexualidade Humana? 2007. Tese de Doutorado pela Universidade de Brasília, Faculdade de Ciências da Saúde. Brasília: 2007. Disponível em: https://repositorio.unb.br/handle/10482/1226 Acesso em: mar 2021

SAMPIERI, R.H.; COLLADO, L.C.F., BAPTISTA, M. D.P. Metodologia de Pesquisa. 5 ed. PortoAlegre: Penso, 2013.

SILVA, Jorge Luiz Lima da et al. Fatores psicossociais e prevalência da síndrome de burnout entretrabalhadores de enfermagem intensivistas. Rev. bras. ter. intensiva. 2015, vol.27, n.2 pp.125-133.

Silva -JUNIOR, J.S. A saúde do trabalhador que cuida da saúde. Rev Bras Med Trab., v.15, 
n.3, 2017. SOUZA E SOUZA LPS, SOUZA AG. Enfermagem brasileira na linha de frente contra o novo Coronavírus:quem cuidará de quem cuida? Journal of nursing and health. 2020.

STARFIELD, B. Atenção primária: equilíbrio entre necessidades de saúde, serviços e tecnologia. Brasília,UNESCO/Ministério da Saúde, 2002. 


\section{CAPÍTULO 06}

\section{DESCRIPTIVE ANALYSIS IN THE COVID-19 DATABASE AFTER ONE YEAR OF THE PANDEMIC DISEASE IN INDIGENOUS PATIENTS FROM THE STATE OF ACRE}

\section{Adolfo Henrique dos Santos Fernandes}

Instituto Federal do Acre

E-mail: adolfo.fernandes@ifac.edu.br

\section{Felipe dos Santos Lopes}

Universidade Federal do Acre

E-mail: lopespge@gmail.com

RESUMO: Há pouco mais de um ano, foi confirmado o primeiro caso de coronavírus no Estado do Acre: em 15 de março de 2020. Desde então, a linha do tempo do coronavírus traz cada vez mais fatos importantes que mostram o tamanho do impacto da pandemia no estado. Neste artigo foram apresentados alguns gráficos estatísticos, como histogramas, gráficos de barras e boxplots, da amostra total e suas respectivas subamostras quando divididos por óbitos e casos recuperados. Após a breve análise descritiva das figuras apresentadas, podemos considerar algumas conclusões sobre a doença COVID-19 em pacientes indígenasno Estado do Acre.

PALAVRAS-CHAVE: Acre; Brasil; Covid-19; Indigenas; Pandemia; Coronavirus.

ABSTRACT: Just over one year ago, the first case of coronavirus in the State of Acre was confirmed: on March 15, 2020.Since then, the coronavirus timeline has brought more and more important facts that show the size of the impact of the pandemic on the state. In this article, some statistical graphs were presented, such as histograms, bar graphs, and boxplots, of the total sample and their respective sub-samples when divided bydeaths and recovered cases. After the brief descriptive analysis of the figures presented, we can consider some conclusions about the COVID-19 disease in indigenous patients in the State of Acre.

KEYWORDS: Acre; Brazil; Covid-19; Indigenous; Pandemic; Coronavirus; 


\section{INTRODUCTION}

Coronaviruses are common in many different animals, including camels, cattle, cats, and bats. Rarely, coronaviruses that infect animals can infect people, as an example of MERS-CoV and SARS-CoV.Recently, in December 2019, took place the transmission of a new coronavirus (SARS-CoV-2), which wasidentified in Wuhan in China and caused the COVID-19 to be disseminated, and then transmitted from person to person (CORONAVIRUS, 2021).

The COVID-19 is a disease caused by the coronavirus, called SARS-CoV2 , which presents avariable clinical spectrum, from asymptomatic infections to severe cases. According to the World HealthOrganization (WHO) ${ }^{1}$, the majority (about 80\%) of patients with COVID-19 can be asymptomatic or oligosymptomatic (few symptoms). Approximately $20 \%$ of the detected cases require hospital care because they have difficulty with respiratory disease, of which approximately $5 \%$ may require ventilatory support. On March 11, 2020, the WHO classified the 2019 Coronavirus disease (COVID-19) as a pandemic.

It means that the virus is circulating in all continents, and there is an occurrence of mildly symptomatic cases, making it challenging to identify. Thus, especially in the southern hemisphere, where Brazil is located, countries must prepare for autumn/winter to avoid increasing deaths (SESACRE, 2021).

Finally, Acre notified its first confirmed case of COVID-19 infection on March 15, 2020. From April 9, 2020, and beyond, the Health Surveillance Secretariat considered that in the cities where cases were registered, had already occurred confirmed of COVID-19 in the community or phase of sustained transmission, as it was not possible to establish an epidemiological link between the cases. Its indigenous population is 15,921, of which 2,595 are urban and 13,326 rural areas, where the ethnicities of the following Alto and Baixo Acre and Juruá and Tarauacá/Envira regions will be analyzed (SESACRE, 2021; IBGE, 2012):

Apurina (Aporina, Ipurina, Ipurinan);

Arara Apolima;

Arara do Acre (Shawanaua, Amawaka);

Kaxinawa (Huni-Kuin, Cachinaua, Caxinaua);

Kulina; 
Machineri (Manchineri, Manxineri);

Yaminawa (Jaminawa, laminawa).

\section{METHODOLOGY}

The used dataset was obtained on March 27 of 2021. It consisted of 1179 (one thousand, one hundred and seventy-nine) information regarding the notification of cases of COVID-19 in the State of Acre. Theycame from surveillance of Influenza Syndrome (SG) and Severe Acute Respiratory Syndrome (SRAG- HOSPITALIZADO) through the Acre State Transparency Portal website2: the Acre Without COVID-19 Pact, which is a management tool for health and socioeconomic crisis caused by the pandemic of COVID-19 in the State of Acre (SESACRE, 2020a; SESACRE, 2020b).

The dataset went through pre-processing steps that allowed us to choose which data items would beworked on, guaranteeing completeness, veracity, and integrity of the information, which allowed the reduction of the amount of data to group them by common characteristics.

After the pre-processing step, the information extracted from the dataset resulted in a total of 304 (three hundred and four) notifications, and we analyzed the following variables:

Age: Discrete quantitative variable, refers to the patient's age;

Gender: Nominal qualitative variable, indicates whether the patient's gender is Female or Male;

Comorbidities: Nominal qualitative variable, these are the comorbidities presented by the patient, being Without for indigenous patients who did not have any health condition and With for indigenous patients who had at least one of these health conditions: Carrier of chromosomal diseases or fragile immune status, Chronic heart diseases, Chronic kidney diseases in advanced stage (3, 4 or 5 grades), Decompensated chronic respiratory diseases, Diabetes, Immunosuppression, Obesity, High-risk pregnant woman or Postpartum (up to 45days after delivery);

Status: Nominal qualitative variable, which is the classification of disease cases, where Recovered are the cases of indigenous patients referring to recovered and the Death are thecases of death. 


\section{RESULTS AND DISCUSSION}

This section is about a descriptive analysis that presents the disease's performance in general. Figure1 illustrates the histogram of age variable where we observe that the ages with the highest frequency are inthe range $[0,10]$ and that the ages with the lowest frequency are in the range [90+], with 0 being the minimum age and 107 the maximum age of indigenous patients who tested positive for COVID-19.]

Figure 1: Histogram of Age

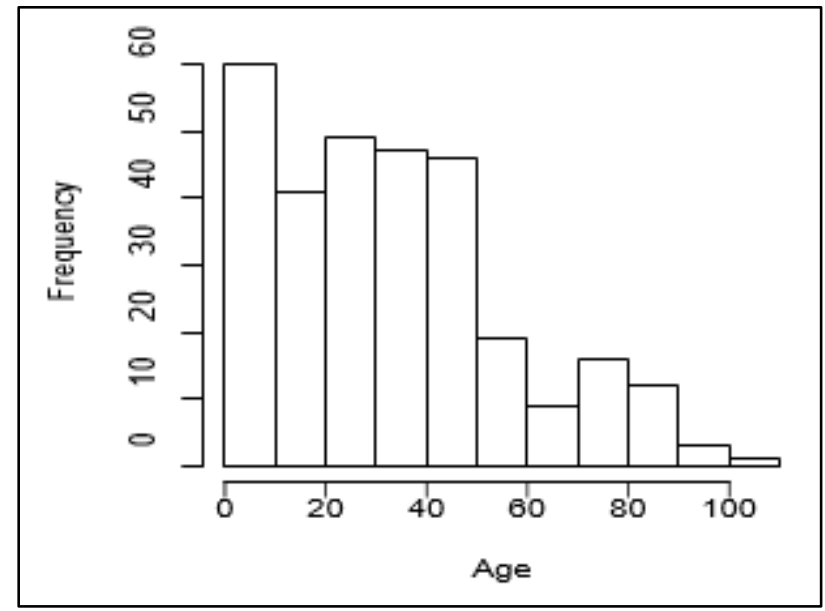

Source: The authors

The barplots of Figure 3 serve to observe the distribution of the frequency of female and male indigenous patients with and without comorbidities (Figure 3a) and who of them died and recovered (Figure3b). We noticed that there is a predominance of females over males in both characteristics in most of them. The only exception is the barplot of death characteristics which male is predominant. 
Figure 2: Boxplots of Gender

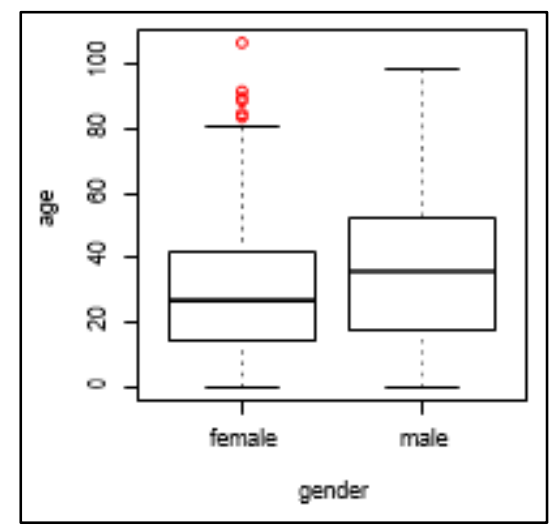

Source: The authors

Now, in Figure 4a, we can see that in the boxplots of the comorbidity's variable, the majority of data from indigenous patients who presented comorbidities are between the ages of 20 and 60 years old, approximately, having no outliers. While most of the data from indigenous patients who did not present comorbidities are between the ages of 20 and 40, approximately, and counted 2 outliers.

Figure 3 : Barplots of Gender by Comorbidities and by Status

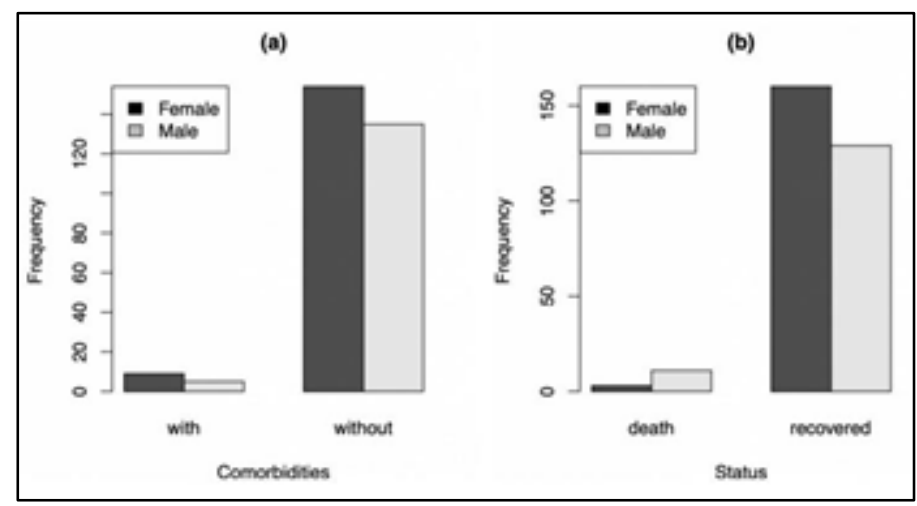

Source : The authors

Now, in Figure 4a, we can see that in the boxplots of the comorbidity's variable, the majority of data from indigenous patients who presented comorbidities are between the ages of 20 and 60 years old, approximately, having no outliers. While most of the data from indigenous patients who did not present comorbidities are between the ages of 20 and 40, approximately, and counted 2 outliers. 
Figure 4 : Boxplots of Comorbidities and Status

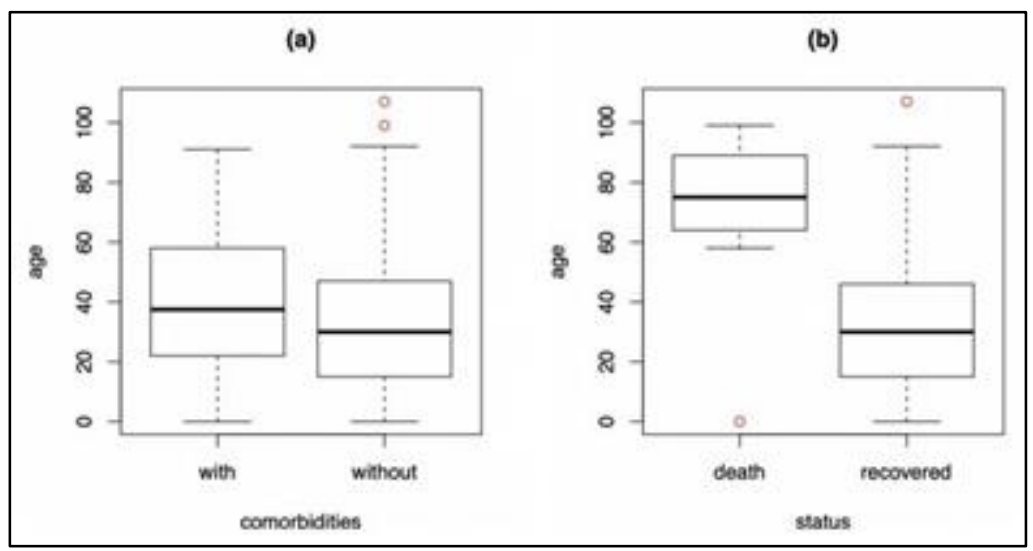

Source : The authors

Figure 4b also illustrates the respective boxplot's graphs for the status variable. Most indigenous patients who died are between ages 60 and 90 years old, approximately, and those indigenous patients counted 1 outlier. While the majority of the data from indigenous patients who recovered are between 20 and 40, approximately, and counted 1 outlier.

\subsection{ABOUT COVID-19 DEATH CASES}

This subsection is about a descriptive analysis that presents the disease's performance in death cases. Figure 5 illustrates the histogram of age variable where we observe that the ages with the highest frequencyare in the range [80, 100+] and that the ages with the lowest frequency are in the range $[20,60]$, with 0 being the minimum age and 99 the maximum age of indigenous patients who died for COVID-19. 
Figure 5 : Histogram of Age of death cases

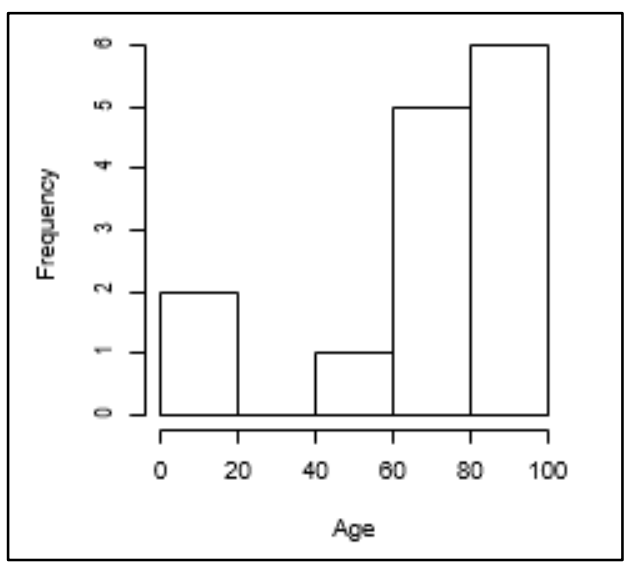

Source: The authors

In Figure 6a, the boxplots for the gender variable shows that most data are distributed between the ages of 40 and 80 years old for the female sex, approximately, having no outliers. While the majority of thedata for the male sex are between the ages of 70 and 80 , approximately, having 1 outlier.

Figure 6: Boxplots of Gender and Comorbidities of death cases

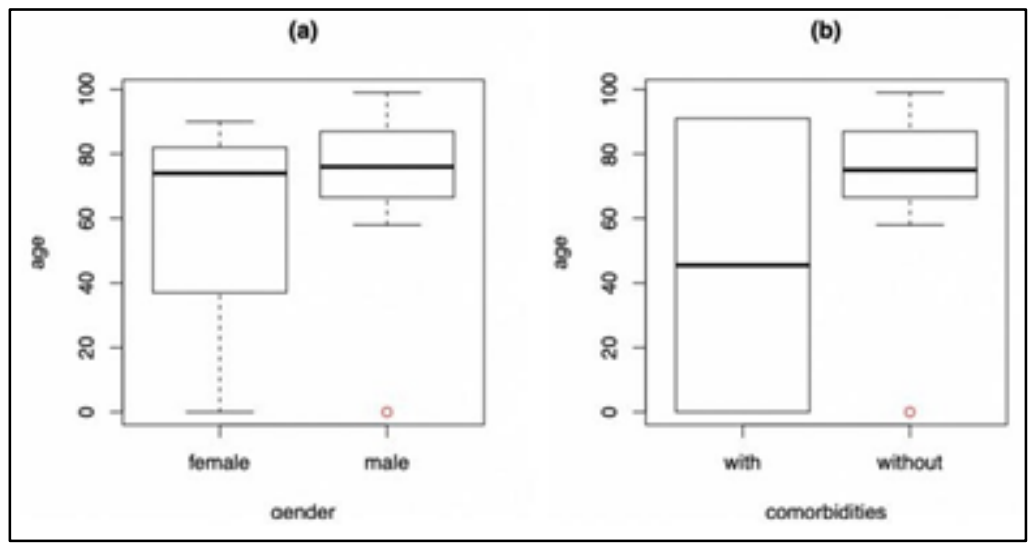

Source : The authors

Also, in Figure 6b, we can see that in the boxplots of the comorbidity's variable, most data are distributed between the ages of 20 and 90 years old for both characteristics, approximately, having high variability and no outliers. While the majority of the data from indigenous patients who did not present comorbidities are between the ages of 70 and 90, approximately, and counted 1 outlier.

Finally, the barplots of Figure 7 serve to observe the distribution of the frequency of female and male indigenous patients who died with and without comorbidities, where it is possible to notice that the male sex was predominant in without characteristic and 
equal to the female sex in with characteristic.

Figure 7 : Barplots of Gender by Comorbidities of death cases

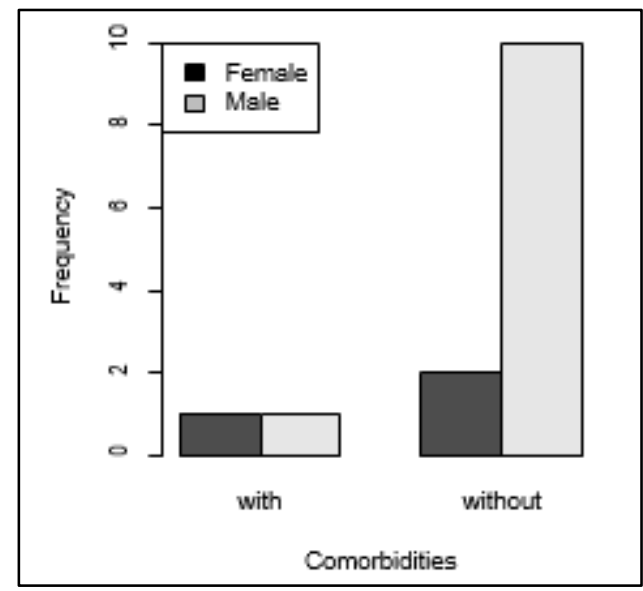

Source : The authors

\subsection{ABOUT COVID-19 RECOVERED CASES}

This subsection is about a descriptive analysis that presents the disease's performance in recoveredcases. Figure 8 illustrates the histogram of age variable where we observe that the ages with the highest frequency are in the range $[0,10]$ and that the ages with the lowest frequency are in the range [90+], with 0 being the minimum age and 107 the maximum age of indigenous patients who recovered for COVID-19.

Figure 8 : Histogram of Age of recovered cases

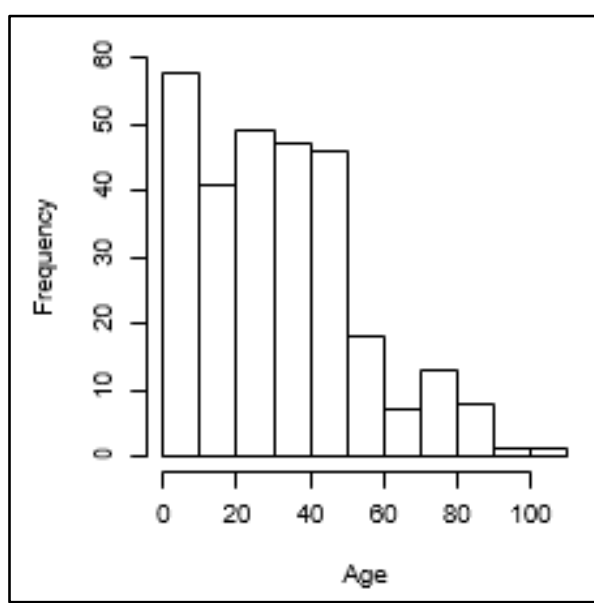

Source: The authors 
In Figure 9a, the boxplots for the gender variable shows that most data are distributed between the ages of 20 and 40 years old for both sexes, approximately, having some outliers in the female sex and nonein the male sex

Figure 9: Boxplots of Gender and Comorbidities of recovered cases

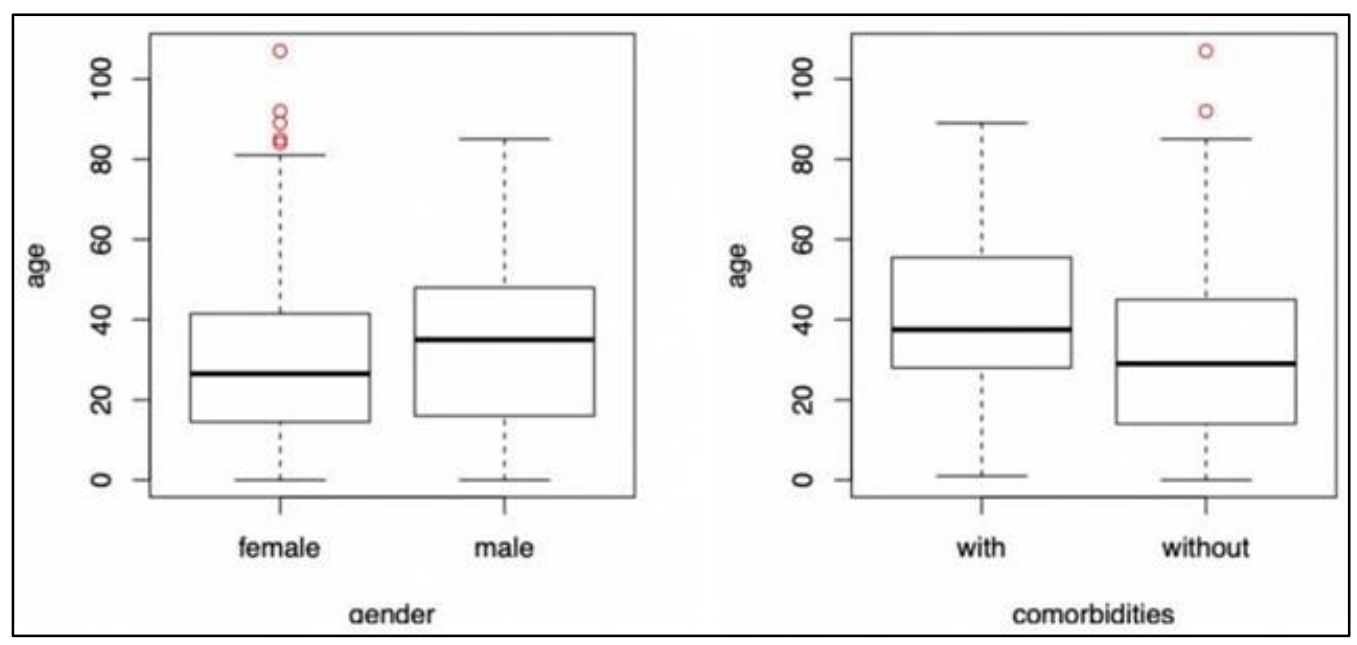

Source : The authors

Also, in Figure 9b, we can see that in the boxplots of the comorbidity's variable, it shows that mostdata are from indigenous patients who presented comorbidities between the ages of 30 and 60 years old, approximately, and none of them had outliers. While most of the data from indigenous patients who did notpresent comorbidities are between the ages of 20 and 50, approximately, and counted 2 outliers.

Finally, the barplots of Figure 10 serve to observe the distribution of the frequency of female and male indigenous patients who recovered with and without comorbidities, where it is possible to notice thatthe female sex was predominant in both characteristics. 
Figure 10 : Barplots of Gender by Comorbidities of recovered cases

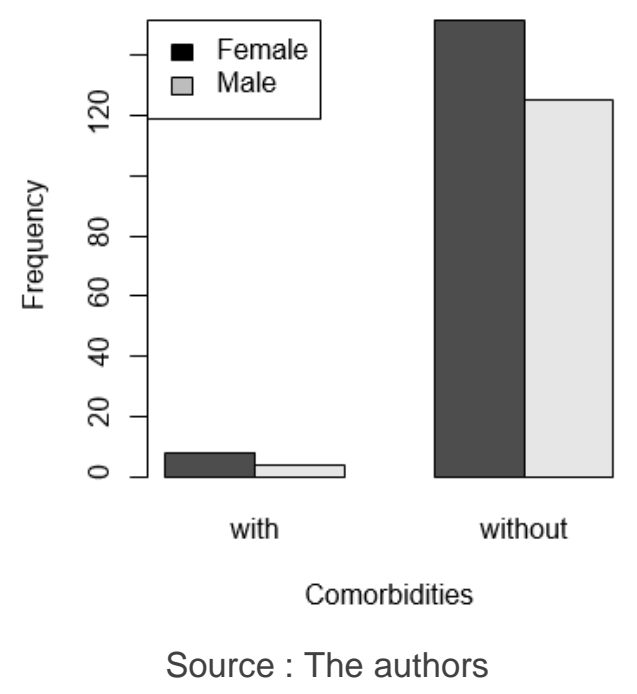

\section{CONCLUSIONS}

The visualization of the data utilizing these graphs: histogram, barplots, and boxplots, made it possible for us to do some conclusions. Starting with the histogram in Figure 1, we noticed that, in general,youngers and adults aged between 0-59 years old tested more favorable to the disease than senior (60+ years) people in both sexes. In previous Figure $3 \mathrm{a}$, we notice that female indigenous patients tested more for comorbidities, with and without health conditions than males ; in Figure 3b, more male indigenous patients died than females.

About death cases, Figure 5 shows a histogram which tells us that more senior indigenous patients died than younger and adult people, who of them died more without than with comorbidities. Furthermore,Figure 8 also shows a histogram telling us that youngers and adults indigenous patients recovered more from the disease than senior people about recovered cases.

Concerning the comorbidities of indigenous patients who died in Figure 7, it is possible to state that they do not contribute negatively to the patient's health status because among the analyzed ages, accordingto the boxplots in Figure 6 and 9, its influence is minimal.

In conclusion, about deaths, it can be seen that $73.33 \%$ (11 cases) occurred in indigenous patients over 60+ years old, $73.33 \%$ (11 cases) in male indigenous patients, and another public with a large share of deaths were indigenous patients 
without comorbidities representing $80.00 \%$ (12 cases) from a total population of 15 indigenous patients. Furthermore, about recovered cases, it can be seen that $58.48 \%$ (169cases) occurred in adult indigenous patients, $55.36 \%$ (160 cases) were female indigenous patients and $95.85 \%$ (277 cases) without comorbidities from a total population of 289 indigenous patients until March 27 of 2021.

\section{ACKNOWLEDGMENT}

The authors would like to thank the Government of the State of Acre for making the COVID-19 database available through the Acre State Transparency Portal website : the Acre Without COVID-19 Pact. 


\section{REFERENCES}

CORONAVÍRUS. Ministério da Saúde, 2021. O que é o coronavírus?.

Disponível em:

<https://www.gov.br/saude/pt-br/coronavirus/perguntas-e-respostas/covid-19/o-que-eo-coronavirus>. Acessado em: 07 de abr. de 2021

IBGE. Instituto Brasileiro de Geografia e Estatística, 2012. Os indígenas no Censo 2010. Disponível em: <https://indigenas.ibge.gov.br/images/indigenas/estudos/indig ena_censo2010.pdf>. Acessado em: 12 de mai. de 2021

SESACRE. Secretaria de Estado de Saúde do Acre, 2020a. Nota Técnica 01 Doença pelo novo coronavírus (COVID 19). Disponível em: <http://covid19.ac.gov.br/static /docs/notas/nota_tecnica_1.pdf>. Acessado em: 04 de mai. de 2021

SESACRE. Secretaria de Estado de Saúde do Acre, 2020b. Relatório Técnico Período

de análise: 16 a 29 de agosto. Disponível em: <http://covid19.ac.gov.br/static/v1/do cs/pacto/6_relatorio_tecnico.pdf>.Acessado em: 29 de ago. de 2020

SESACRE. Secretaria de Estado de Saúde do Acre, 2021. Plano de Contingência para Enfrentamento da Pandemia Ocasionada pelo Novo Coronavírus, o Sars-CoV-2. Disponível em: <https://agencia.ac.gov.br/wpcontent/uploads/2021/04/Acre-Plano-COVID-19-7ª-VERSÃO-.pdf>. Acessado em: 23 de abr. de 2021 


\section{CAPÍTULO 07}

ESTRATÉGIAS DE CUIDADO EM SAÚDE REALIZADAS PELAS EQUIPES DE CONSULTÓRIO NA RUA/BOMPAR/SMS. JUNTO À POPULAÇÃO EM SITUAÇÃO DE RUA DURANTE A PANDEMIA NO MUNICÍPIO DE SÃO PAULO

\section{Marta Regina Marques Akiyama}

Gestora de Saúde do Consultório na Rua, unidades odontológicas para pessoas em situação de rua do Município de São Paulo Centro Social Nossa Senhora do Bom Parto/ Secretaria Municipal de Saúde de São Paulo - Formação: Assistente Social e Terapeuta Sistêmica

E-mail: marta.saudenarua@gmail.com; marta.saudenarua@bompar.org,br

\section{Rhavana Pilz Canônico}

Enfermeira e interlocutora de Saúde equipes da Região Sul- centro social nossa Senhora do Bom Parto/ Secretaria Municipal de Saúde de São Paulo

E-mail: rhavana@bompar.org.br

\section{Rodrigo Sette}

Psicólogo e interlocutor técnico Região Sudeste, Centro Social Nossa Senhora do Bom Parto/ Secretaria Municipal de Saúde de São Paulo

E-mail: rodrigo@bompar.org.br

\section{Maria Cristina Barboza Kawakami}

Enfermeira do Consultório na Rua Centro social nossa senhora do Bom Parto/ Secretaria Municipal de Saúde de São Paulo

E-mail: cnrua.admbompar@bompar.org.br

RESUMO: No presente, abordaremos as estratégias de cuidado em saúde realizadas pelas equipes de Consultório na Rua geridas pelo Centro Social Nossa Senhora do Bom Parto (Bompar) em parceria com a Secretaria Municipal de Saúde durante a pandemia junto à população em situação de rua no Município de São Paulo na perspectiva da prevenção bem como do acompanhamento da saúde das pessoas em situação de rua com suspeita e confirmação de COVID-19. Dentro do cenário em que milhares de pessoas estão vindo a óbito o percentual de pessoas em situação de rua está em 1/3, ou seja, inferior da população residente. Tendo em vista, muitas especulações a respeito da "baixa" taxa de óbitos por COVID 19. A estratégia adotada tem sido um grande aliado na prevenção da doença e na promoção dos cuidados necessários, antecipando assim a piora e o agravo da doença. Este monitoramento é realizado por mais de 530 profissionais diariamente nas ruas e dentro dos Centros de Acolhida, além dos espaços emergenciais COVID I e II, abertos pela Secretaria de Saúde na Gestão do Secretário Edson Aparecido dos Santos. O pronto atendimento e a busca ativa diária de pacientes com sintomas gripais ou qualquer outra manifestação que seja diferente da rotina do cidadão, tem sido fundamental, pois permite identificar situações de agravamento do quadro de saúde e os devidos encaminhamentos imediatos para a rede de urgência e emergência do território, agiliza o diagnostico possibilitando o não agravamento da doença, evitando assim mais mortes. 
PALAVRAS-CHAVE: Covid-19 na população de rua de São Paulo.

ABSTRACT: At the moment, we've approached health care strategies for the homeless carried out by the Street Outreach Program teams managed by the Social Center Nossa Senhora do Bom Parto (Bompar) in partnership with Municipal Health Department while this pandemic time in Sao Paulo city, looking towards to the prevention as well as monitor cases that are considered to be suspect or confirmed been infected by SARS-CoV-2. In a scenery that thousands of people are dying, the percentual of deaths among the homeless is $1 / 3$, in other words, less than the resident population in general. Considering various speculations about death low rates by SARS-CoV-19 the adopted strategy is been a great alternative for the infection prevention to promote necessary care in order to prevent the infection complications. This monitoring is daily accomplished by more than 530 professionals on the streets and inside of comum shelters, beyond the emergency shelters SARS-CoV-19 I e II, opened by Municipal Health Department managed by the Secretary Edson Aparecido dos Santos. The prompt service and the daily search for people who presents early flu-like symptoms or any other unusual sign os the disease is been essential, because it allows to identify situations that may carry it for a worse and immediately send them to an emergency hospital of the territory, streamlining the diagnose helping the patient not to get worse and thus avoid deaths.

KEYWORDS: Covid-19 in the street population of São Paulo 


\section{JUSTIFICATIVA}

As orientações de prevenção à pandemia somam-se aos desafios cotidianos enfrentados pela população em situação de rua, onde devemos sempre considerar os diferentes contextos de vida dos indivíduos e incluir propostas condizentes frente ao cenário em que vivem. Por outro lado, as políticas públicas também devem, embasadas nas orientações do Ministério da Saúde (BRASIL, 2020), manter medidas de prevenção contra o novo coronavírus, como a necessidade do distanciamento social, uso de máscaras e higienização frequentes das mãos. Se para a população geral tem sido um desafio seguir estas orientações, imaginem para as pessoas que não possuem casas, moram nas ruas da cidade ou vivem em albergues? As medidas divulgadas pela OMS divergem das peculiaridades e circunstâncias nas quais vivemas pessoas em situação de rua. Como ficar em casa, se as pessoas não possuem casa? Como evitar aglomerações se os centros de acolhida são conhecidos justamente por aglomerar pessoas, muitas vezes sem o distanciamento ou ventilação adequada? Como lavar bem as mãos, se o acesso à água e itens básicosde higiene é tão precário?

Entretanto os estudos e pesquisas relacionadas à COVID-19 são constantes e ainda há perguntas que requerem respostas justamente para elaboração de políticas públicas mais direcionadas e eficazes, principalmente no que concerne às populações mais vulneráveis. Torna-se fundamental, portanto, aexposição de experiências que trazem consigo boas práticas e que possam embasar proposituras a fim de minimizar os riscos de infecção e agravamento da doença em uma população em extrema vulnerabilidade social e de saúde como as pessoas que vivem em situação de rua.

O objetivo deste é apresentar as experiências de trabalho realizadas pelas equipes de Consultório naRua do Município de São Paulo, contratadas pela SMS e Bompar que atuam diretamente com a população em situação de rua durante a pandemia e por meio delas, suscitar reflexões, ou mesmo auxiliar na condução de ideias de diferentes profissionais das diversas frentes de trabalho que também atuam junto a esta vulnerabilidade social neste contexto pandêmico. 


\section{OS CONSULTÓRIOS NA RUA DE SÃO PAULO ENQUANTO POLÍTICA PÚBLICA NO ENFRENTAMENTO DA PANDEMIA JUNTO À POPULAÇÃO EM SITUAÇÃO DE RUA}

As equipes de Consultórios na Rua (eCR) foram instituídas pela Política Nacional de Atenção Básica por meio da Portaria № 122 de 2012 e fundamentadas na Política Nacional para a População em Situação de Rua decretada em 2009 que assegura os direitos das pessoas em situação de rua no país de acesso amplo, simplificado e seguro aos serviços e programas que integram as diversas políticas públicas. As eCR possuem os objetivos de atuarem no cuidado integral em saúde da população em situação de rua; realizar atendimentos in loco, gerar e ampliar o acesso aos serviços do Sistema Único de Saúde (SUS) e darede intersetorial.

Tais objetivos devem partir da escuta qualificada e do acolhimento das demandas trazidas pelas pessoas em situação de rua, portanto a "porta de entrada" é o encontro entre o profissional da equipe e a pessoa na rua. É desse encontro que surgem as articulações da rede e o planejamento das ações de prevenção, promoção de saúde e cuidado nos diferentes pontos de atenção à saúde e da rede Intersetorial.

Os Consultórios na Rua também integram o componente "atenção básica" na Rede de Atenção Psicossocial (RAPS) operando frente aos problemas relacionados ao álcool, crack e outras drogas (BRASIL, 2012).

Uma característica importante e louvável das Equipes Consultório na Rua BOMPAR/SMS, é a oportunidade de empregabilidade dada às pessoas que estiveram ou ainda se encontram em situação de vulnerabilidade social, onde é ofertado a oportunidade de participarem de processo seletivo para o cargo deAgente de Saúde, seguindo os critérios necessários para admissão. A pregressa vivência nas ruas, a resiliência emergida pela fragilidade ou perdas que tiveram ao longo da vida, facilita a aproximação do Agente de Saúde com o público alvo, uma vez que promove a empatia, capacidade de se identificar com oque o outro vive e sente, tornando-se fundamental para a construção de vínculo, ferramenta substancial parao processo de trabalho das equipes de Consultório na Rua (AKIYAMA, 2020).

$\mathrm{Na}$ cidade de São Paulo, existem 26 Equipes de Consultório na Rua (eCR), sendo 25 delas contratadas pelo Bompar em parceria com a Secretaria Municipal de Saúde. Essas eCR estão alocadas emtodas as seis regiões territoriais do município: 
Centro, Sudeste, Oeste, Leste, Norte e Sul. Destaca-se que cada um desses territórios apresenta contextos diferentes no que concerne tanto ao perfil e dinâmica das pessoas em situação de rua como à oferta de serviços.

As eCR são compostas por médicos, enfermeiros, auxiliares de enfermagem, assistentes sociais, psicólogos, agentes sociais, agentes de saúde, assistente técnico administrativo e motoristas com seus veículos.

Considerando sua dimensão de alcance, as equipes de Consultório na Rua/Bompar são dispositivos fundamentais enquanto política de saúde pública configurando-se a "linha de frente" no enfrentamento contra a COVID-19 junto à população em situação de rua no município.

\section{AS ESTRTÉGIAS DE CUIDADO EM SAÚDE DAS EQUIPES DE CONSULTÓRIO NA RUA DURANTE A PANDEMIA DE COVID-19 NA PERSPECTIVA DA PREVENÇÃO: CAMPANHA \#SEPARADOS SOMOS MAIS FORTES}

Após a deflagração da pandemia e considerando o modo de vida das pessoas em situação de rua, fez-se necessária a capilarização, ou seja, a disseminação in loco, das orientações de medidas de prevençãoe a oferta dos itens de proteção contra a COVID19 a essa população.

Ademais, é fundamental, sobretudo, assegurar o acesso às informações fundamentadas em conhecimento técnico científico, uma vez que as mídias sociais exerceram influência significativa na disseminação de falsas notícias, as chamadas fake news, principalmente aos trabalhadores dos serviços de acolhimento que se tornam multiplicadores das informações e estão em contato mais próximos com as atividades de vida diárias dos conviventes acolhidos.

A campanha \#Separados Somos Mais Fortes (em referência ao distanciamento social) consistiu emações realizadas constantemente durante a pandemia pelas eCR/Bompar promovendo orientações sobre a COVID-19 e medidas de prevenção atreladas à distribuição de itens de proteção como máscaras faciais e recipientes com álcool em gel 70\% nos diversos logradouros da cidade de São Paulo.

Apesar do foco em comum, as equipes buscaram estratégias de promoção e prevenção em saúde de acordo com as necessidades locais. Com a falta de Centros/Núcleos de Convivência em alguns territórios, as eCR lançaram mão de 
parcerias com associações de bairro, fundações, cooperativas, organizações religiosas, movimentos, redes, coalizões de grupos e coletivos da sociedade civil para atender as necessidades básicas como alimentação e banho.

Presente no cotidiano de trabalho das eCR, a criatividade é uma potente ferramenta na elaboração de estratégias. Em alguns locais, por exemplo, profissionais das equipes penduraram dois recipientes, um com água e outro com sabão, nas árvores para higienização das mãos.

Apesar destas informações estarem disponíveis por meio de veículos de comunicação, manuais devigilância e notas técnicas institucionais, nunca se deve abrir mão da escuta qualificada realizada durante essas ações. Por meio dela é possível conhecer as dificuldades encontradas relacionadas às medidas de prevenção e junto com o usuário, pensar diferentes possibilidades de minimizar os riscos de transmissão donovo coronavírus, o empoderando sobre seu autocuidado.

A campanha \#Separados Somos Mais Fortes tornou-se parte do processo de trabalho diário das eCR, uma vez que não basta apenas uma ação educativa, mas é necessário fazer-se presente, de forma contínua, in loco, acompanhando os desafios das pessoas em situação de rua frente à pandemia e junto com elas descobrir possibilidades de enfrentar este fatídico momento planetário.

\section{ACOMPANHAMENTO DA SAÚDE DAS PESSOAS EM SITUAÇÃO DE RUA COM SUSPEITA E CONFIRMAÇÃO DE COVID-19}

Além das ações relacionadas à prevenção contra a COVID-19, as eCR atuam no diagnóstico da COVID-19 e acompanhamento do cuidado das pessoas em situação de rua infectadas.

Diariamente, inclusive aos finais de semana, os profissionais de que compõem as Equipes realizamo monitoramento tanto das pessoas que moram nos logradouros públicos, áreas livres, como das pessoas que vivem nos Centros de Acolhida da capital.

Esse monitoramento consiste em realizar busca ativa de sintomáticos respiratórios e sintomáticos para COVID-19. Ao questionar os usuários sobre o aparecimento de sintomas e verificar os sinais vitais como temperatura, saturação e frequência respiratória, é seguido as orientações de prevenção e encaminhamento 
para isolamento, nos casos de suspeita ou casos confirmados de COVID-19. Esses procedimentos são direcionados para todo o público mencionado, com um olhar atento principalmente nas pessoas pertencentes ao grupo de risco, idosos e/ou pessoas com agravos em saúde associados, tais como hipertensão, diabetes, tuberculose, HIV entre outros.

As eCR preenchem um sistema de informação interno do Bompar em formato de planilha com os dados de todas as pessoas com agravos em saúde, incluindo os sinais e sintomas avaliados bem como todos os sintomáticos identificados. Esse sistema de informação é fundamental para o acompanhamento dos casose para fins estatísticos.

Assim que identificados, os casos sintomáticos são direcionados para a coleta de RT -PCR ${ }^{1}$ ou diretamente para o Centro de Acolhida Emergencial COVID-II "Pelezão" destinado para isolamento das pessoas com suspeita da doença, onde poderão realizar a coleta do exame no local por equipes de saúde contratadas pelo próprio Bompar para a assistência e cuidado em saúde dos usuários.

Já os usuários com diagnóstico positivo para a COVID -19 são encaminhados ao Centro de Acolhida Emergencial COVID I "Bacelar", onde também há uma equipe de saúde do Bompar para assistência em saúde no local.

Diferentemente do monitoramento da população geral no município que ocorre por meio de contatotelefônico, logicamente o monitoramento pelos profissionais de saúde da população em situação de rua ocorre de forma presencial, diariamente, junto às pessoas infectadas. Isso contribui para minimizar os riscos de agravamento da doença de maneira mais efetiva.

Os Centros de Acolhida Emergenciais são gerenciados pela Secretaria Municipal de Desenvolvimento e Assistência Social do Município de São Paulo (SMADS). Portanto, o processo de trabalho nestes serviços configura expressamente a intersetorialidade tão necessária no trabalho com a população em situação de rua, uma vez que são equipamentos da Assistência Social, mas com acompanhamento conjunto entre as equipes da SMADS e da Saúde.

As equipes de saúde contratadas para assistência nos Centros de Acolhida Emergenciais são compostas por médico, enfermeiro e auxiliares de enfermagem e são responsáveis pelo acompanhamento do cuidado em saúde dos usuários acolhidos. 
Diariamente, estas equipes de saúde realizam admissão de pacientes, consultas médicas e de enfermagem, coletas de exames, altas médicas e, especificamente no Centro de Acolhida Emergencial COVID II "Pelezão", realizam o relatório de transferência para o Centro de Acolhida Emergencial COVIDI "Bacelar" quando diagnosticam usuários com COVID-19.

Reitera-se sobre a importância da criação dos Centros Emergenciais COVID19 neste modelo apresentado, e neste momento de Pandemia e cuidado da população mais vulnerável, como um modelo a ser seguido, pensando na construção de trabalho compartilhado, participativo e interativo entre as diferentespastas, da Saúde e da Assistência Social.

\section{CONSIDERAÇÕES FINAIS}

Se por um lado, a pandemia trouxe intenso sofrimento a muita gente, por outro aguçou instintos desolidariedade. Os invisíveis tornaram-se visíveis aos olhos da sociedade em geral, mesmo que em algumas reflexões, falas ou reportagens no período de pandemia.

No que tange à prevenção contra a COVID - 19, destacam-se a necessidade de convergir estratégias com o modo de vida das pessoas em situação de rua e a manutenção dessas estratégias, considerando os desafios enfrentados por esta população relacionados às medidas de prevenção contra o novo coronavírus. As eCR foram fundamentais nesse cenário, uma vez que se configuram como uma política pública de saúdepara esta vulnerabilidade social.

No âmbito do cuidado em saúde das pessoas em situação de rua com suspeita e confirmação de COVID-19, destacamos a intersetorialidade como principal ferramenta de trabalhopois ambas as equipes, da Assistência Social e da Saúde precisam trabalhar mutuamente e de maneira transdisciplinar, uma vez que atuam no mesmo espaço físico e social.

Apresentamos abaixo, dados que representam a importância do cuidado diário realizado pelas Equipes CNR desde o início da Pandemia para a prevenção e promoção da saúde das pessoas em situaçãode rua. 
Tabela 1: Cuidado diário

\begin{tabular}{|l|c|c|c|}
\hline & Ano de Referência & $\mathbf{2 0 2 1}$ & $\mathbf{2 0 2 0}$ \\
\hline Abordagens & & 66.139 & 231.005 \\
\hline Consultas Medicas & & 13.027 & 43.542 \\
30.515 & & 19.213 & 63.258 \\
\hline $\begin{array}{l}\text { Consultas de Enfermagem } \\
44.045\end{array}$ & & 2.859 & 12.470 \\
\hline $\begin{array}{l}\text { Ações de Covid-19 realizadas nos equipamentos } \\
\text { sociais e rua (orientação, busca ativa e outros) } \\
9.611\end{array}$ & & & \\
\hline
\end{tabular}

Fonte: Os autores

Devemos enfim, lembrar que é necessário cuidar daqueles que ficam nos bastidores, os profissionaisque estão na linha de frente, que lidam diretamente e diariamente nesse cotidiano de incertezas e desafios,considerando a exposição aos riscos de contaminação que podem adoecer não apenas fisicamente, mas mentalmente, aqueles que são, atualmente, considerados os heróis contra a pandemia. 


\section{REFERÊNCIAS}

AKIYAMA, M. R. M. População de Rua no Empoderamento do Acesso à Saúde. Archives of Health, v. 1,n. 5, p. 341-345, 23 Dec. 2020.

CANONICO, R. P. et al. Atendimento à população de rua em um Centro de Saúde Escola na cidade de SãoPaulo. Rev. esc. enferm. USP, São Paulo, v. 41, n. spe. 799-803, Dec. 2007.

CARNEIRO JUNIOR, N.; JESUS, C. H.; CREVELIM, M. A. A Estratégia Saúde da Família para a equidade de acesso dirigida à população em situação de rua em grandes centros urbanos. Saúde e Sociedade,São Paulo, v.19, n. 3, p.709-716, 2010.

BRASIL. Decreto Presidencial no 7.053, de 23 de dezembro de 2009. Institui a Política Nacional para a População em Situação de Rua e seu Comitê Intersetorial de Acompanhamento e Monitoramento, e dá outras providências. Brasília, 2009. Disponível em: Decreto oㅜ 7053 (planalto.gov.br). Acesso em: 17 abr.2021.

BRASIL. Ministério da Saúde. Secretaria de Atenção à Saúde. Departamento de Atenção Básica. Manual sobre o cuidado à saúde junto à população em situação de rua. Brasília: Ministério da Saúde, 2012. 98 p.

Ministério da Saúde. Portaria no 122, de 25 de janeiro de 2011. Define as diretrizes de organizaçãoe funcionamento das Equipes de Consultório na Rua. Brasília: Ministério da Saúde, 2012. Disponível em: Ministério da Saúde (saude.gov.br). Acesso em: 17 abr. 2021.

- Ministério da Saúde. Secretaria de Atenção Primária à Saúde. Prevenção ao Covid-19 no Âmbitodas Equipes de Consultórios na Rua. Brasília - DF: Ministério da Saúde, mar. 2020.

Ministério da Saúde. Secretaria de Vigilância em Saúde. Guia de Vigilância Epidemiológica. Emergência de saúde pública de importância nacional pela doença pelo coronavírus 2019. Brasília - DF: Ministério da Saúde, 15 mar. 2021.

SÃO PAULO. Secretaria Municipal de Desenvolvimento e Assistência Social. Nota

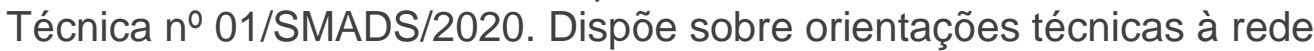
socioassistencial a serem seguidas durante o período de emergência. São Paulo: Secretaria Municipal de Desenvolvimento e Assistência Social, 24 mar.2020.

SÃO PAULO. Secretaria Municipal de Saúde. Coordenação de Atenção à Saúde. Orientações para os Profissionais do Consultório na rua e Redenção na Rua COVID-19. São Paulo: Secretaria Municipal de Saúde, 2020.

SÃO PAULO. Prefeitura Municipal. Orientações para pessoas em situação de rua. Novo coronavírus (COVID-19). São Paulo, mar. 2020. 


\section{CAPÍTULO 08}

OBESIDADE E COVID-19: DUAS EPIDEMIAS QUE, COMBINADAS, REPERCUTEM EM MAU PROGNÓSTICO DE PACIENTES

Iluskhanney Gomes de Medeiros Nóbrega Miranda

Iluskhanney Gomes de Medeiros Nóbrega Miranda

UNINASSAU - Centro Universitário Maurício de Nassau, Nutrição

E-mail : yluska.gmn@gmail.com

Lattes: http://lattes.cnpq.br/6850313395772100

Orcid: https://orcid.org/0000-0002-6376-6658

\section{Ingrid Rafaella Maurício Silva Reis}

Nutricionista, UPE - Universidade de Pernambuco, Mestranda em biociências, UNIVASF

E-mail : ingridrafa.15@gmail.com

Lattes: http://lattes.cnpq.br/8955735366807624

Orcid: https://orcid.org/0000-0001-7924-9623

\section{Isadora Garcia Pires}

Nutricionista - UNIPAM - Centro Universitário de Patos de Minas

E-mail : isadoragarciapires@gmail.com

Lattes: http://lattes.cnpq.br/9712541228805042

Orcid: https://orcid.org/0000-0003-2248-9735

\section{Dr. Juscelino Kubitschek Bevenuto da Silva}

UNINASSAU-Professor do Centro Universitário Maurício de Nassau/Campina

Grande-PB

E-mail : nutribevenuto@hotmail.com

Lattes: http://lattes.cnpq.br/9078339188121776

Orcid: https://orcid.org/0000-0003-4266-8140

RESUMO: A obesidade, em si, trata-se de uma doença crônica, inflamatória, de origem multifatorial onde diversos fatores podem estar envolvidos, como: hereditariedade, hábitos adquiridos ao longo da vida e fatores ambientais, sendo considerada uma condição pandêmica no mundo. Indivíduos que apresentam o dignóstico nutricional de obesidade e, também, outros fatores de riscos que pioram o quadro, como já mencionado, possuem maiores chances de desenvolverem outras comorbidades, tais como, cardiopatias, diabetes, câncer, hipertensão e problemas respiratórios, patologias essas vulneráveis a levarem a um prognóstico desfavorável quando associado com a infecção pelo COVID 19. Este artigo de revisão bibliográfica teve como objetivo verificar de que forma a obesidade pode ser um fator de risco para um mau prognóstico diante de pacientes acometidos pelo novo coronavírus. A seleção e localização das referências que fundamentassem esta revisão foram retiradas das bases de dados PubMed/LILACS e da biblioteca eletrônica SciELO, utilizando também a Biblioteca Virtual em Saúde (BVS), a fim de identificar artigos científicos publicados no período de 2020 e 2021, utilizando como descritores: obesidade e covid-19; fatores de risco e Covid-19; obesidade e Sars-Cov-2 e suas versões em inglês. A literatura evidencia que o estado obesogênico pode conduzir para um mau prognóstico em 
pacientes obesos e infectados com SARS-CoV-2. Podemos observar que o grau de comprometimento da saúde é independente do grau de obesidade, sendo que a medida que este aumenta, os riscos de internação e intubação ou morte em comparação com os pacientes sem obesidade, aumentam substancialmente. Algumas condições exercem grande influência sobre o mal prognóstico, são exemplos, a distribuição do tecidoa adiposo, quando essa reserva se acumula na parte visceral, contribui para resistência a insulina, dislipidemia, aterosclerose, inflamação, diabetes II, síndrome metabólica e maior risco de DCV e tatmbém, o próprio estado inflamatório característico da obesidade.

PALAVRAS-CHAVE: Fator de Risco; SARS-CoV-2; Estado nutricional; Obesidade.

ABSTRACT: Obesity, in itself, is a chronic, inflammatory disease, of multifactorial origin where several factors may be involved, such as: heredity, habits acquired throughout life and environmental factors, being considered a pandemic condition in the world. Individuals who have the nutritional status of obesity and, also, other risk factors that worsen the condition, as already mentioned, are more likely to develop other comorbidities, such as heart disease, diabetes, cancer, hypertension and respiratory problems, pathologies that are vulnerable to lead to an unfavorable prognosis when associated with the infection by COVID 19. This Bibliographic Review article aimed to verify how obesity can be a risk factor for a poor prognosis for patients affected by the new coronavirus. The selection and location of the references that supported this review were taken from the PubMed / LILACS databases and the SciELO electronic library, also using the Virtual Health Library (VHL), in order to identify scientific articles published in the period 2020 and 2021, using as descriptors: obesity and covid-19; risk factors and Covid-19; obesity and Sars-Cov-2 and their English versions. The literature shows that the obesogenic status can lead to a poor prognosis in obese patients and those infected with SARS-CoV-2. We can observe that the degree of health impairment is independent of the degree of obesity, and as it increases, the risks of hospitalization and intubation or death compared to patients without obesity, increase substantially. Some conditions have a great influence on the poor prognosis, for example, the distribution of adipose tissue, when this reserve accumulates in the visceral part, contributes to insulin resistance, dyslipidemia, atherosclerosis, inflammation, diabetes II, metabolic syndrome and increased risk of CVD and also, the inflammatory state characteristic of obesity.

KEYWORDS: Risk Factor; SARS-CoV-2; Nutritional status; Obesity. 


\section{INTRODUÇÃO}

Grandes mudanças ocorreram no processo saúde/doença nos últimos anos, principalmente, a partir da metade do século XX, no qual foi percebido e se instalado, de maneira grandiosa e significativa, uma transição nutricional, caracterizada por uma superposição de carências nutricionais globais como o sobrepeso e a obesidade, condições essas associadas com múltiplas consequências adversas à saúde (MELO et al., 2020).

O sobrepeso e a obesidade podem ser definidos como um distúrbio nutricional e metabólico, o qual é caracterizado pelo aumento da quantidade de gordura corporal, além do padrão aceitável de normalidade, resultando, assim, no aumento do peso corpóreo. Tais condições se integram ao grupo das doenças crônicas não transmissíveis (DCNT) e representam fatores de riscos importantes de morbimortalidade em populações adultas (MELO et al., 2020; DIAS et al., 2017).

A obesidade, em si, trata-se de uma doença crônica, inflamatória, de origem multifatorial onde diversos fatores podem estar envolvidos, como: hereditariedade, hábitos adquiridos ao longo da vida e fatores ambientais, sendo considerada uma condição pandêmica no mundo. No entanto, o consumo de calorias maior que o necessário é a principal característica para o quadro patológico (SBP, 2019).

A Organização Mundial de Saúde (OMS) define a obesidade com base no Índice de Massa Corporal (IMC) definido pelo cálculo do peso corporal, em quilogramas, dividido pela altura ao quadrado, em metros quadrados $\left(I M C=\mathrm{kg} / \mathrm{h}^{2}(\mathrm{~m})\right.$ ), e também pelo risco de mortalidade associada. A obesidade é caracterizada quando o IMC encontra-se acima de $30 \mathrm{~kg} / \mathrm{m}^{2}$, salientando que ainda há uma estratificação dos graus de obesidade (graus I, II e III) (OMS, 1995).

Já em outro cenário, a doença do novo coronavírus "COVID-19", nomeada pela Organização Mundial da Saúde (OMS) declarada como Pandemia Global em março de 2020, é considerada uma morbidade conduzida pelo vírus SARS-CoV-2 de RNA de cadeia positiva, o qual traz consigo consequências como efeitos deletérios ao sistema respiratório, e intestinal em alguns hospedeiros, acarretando desde sintomas leves até mortais (ABBAS et al., 2020; CUMMINGS et al., 2020).

Indivíduos que apresentam o dignóstico nutricional de obesidade e, também, outros fatores de riscos que pioram o quadro, como já mencionado, possuem maiores 
chances de desenvolverem outras comorbidades, tais como, cardiopatias, diabetes, câncer, hipertensão e problemas respiratórios, patologias essas vulneráveis a levarem a um prognóstico desfavorável quando associado com a infecção pelo COVID 19 (CARNEIRO \& DALL'IGNA, 2020).

Os efeitos de um IMC elevado na mortalidade de COVID-19 podem ser mais fortes para mulheres. Por outro lado, há evidências de prevalência 42 vezes maior para o desenvolvimento de pneumonia grave em pacientes obesos, comparando com aqueles em estado eutrófico, sendo o público masculino 4,4 vezes maior de progressão para a gravidade em relação ao feminino. De todo modo, chama-se a atenção para a obesidade manter-se associada a maiores complicações em diferentes estudos, em ambos os sexos (PETERS, SAE. et al., 2020; QINGXIAN, C. et al., 2020).

O chamado "Choque de pandemias", é um termo recentemente abordado, o qual traduz a associação da ocorrência da infecção pelo novo coronavírus e a obesidade, ou seja, refere-se a pacientes acometidos por duas doenças com perfil pandêmico simultaneamente (CARNEIRO \& DALL'IGNA, 2020).

Existem múltiplos mecanismos possíveis e potenciais que colocam a obesidade como um fator de risco agravante para infecção por SARS-CoV-2, dentre eles: a alta deposição de gordura corporal sobre as vísceras e órgãos, que pode está associado com a redução da função de proteção cardiorrespiratória, resultando em uma função pulmonar prejudicada; o estado inflamatório característico da obesidade, podendo esse ser o principal fator, entre outros (CARNEIRO \& DALL'IGNA, 2020).

Tendo em vista tais definições bem elucidadas diante da literatura, torna-se necessário realizar estudos diante da temática, uma vez que a pandemia da COVID19 emergiu de forma ardilosa, trazendo consigo grande exponencial quando colidindo com outras pandemias globais mais antigas, a exemplo da obesidade, repercutindo em maior vulnerabilidade do quadro clínico dos portadores e mortalidade.

Diante disso, o objetivo desta revisão bibliográfica é verificar de que forma a obesidade pode ser um fator de risco para um mau prognóstico diante de pacientes acometidos pelo o novo coronavírus.

\section{METODOLOGIA}

Trata-se de uma pesquisa de revisão bibliográfica integrativa. Para assegurar 
a consecução do objetivo descrito, realizou-se um estudo exploratório e a seleção e localização das referências que fundamentassem esta revisão foram retiradas das bases de dados PubMed/LILACS e da biblioteca eletrônica SciELO, utilizando também a Biblioteca Virtual em Saúde (BVS), que integra as bases de dados acima citadas, a fim de identificar artigos científicos publicados no período de 2020 e 2021, utilizando os seguintes descritores: obesidade e covid-19; fatores de risco e Covid-19; obesidade e Sars-Cov-2 e suas versões em inglês.

Os critérios adotados de inclusão para as referências a serem utilizadas foram: artigos publicados nos idiomas português e inglês, disponíveis na íntegra, com acesso eletrônico livre e que correspondessem ao conteúdo da análise. Quanto aos de exclusão, foram descartados os estudos nos idiomas espanhóis, artigos repetidos, revisões bibliográficas e aqueles que não estivessem em consonância com a proposta desta produção ou que não se enquadraram nos critérios de inclusão mencionados a partir da leitura dos títulos e dos resumos de cada um dos artigos científicos selecionados.

\section{RESULTADOS E DISCUSSÃO}

A busca inicial resultou em 196 publicações as quais tiveram os seus respectivos resumos apreciados. Após filtragem, foram selecionados 45 estudos para uma leitura completa e selecionados 12 artigos como base para esta revisão bibliográfica. Desses, 6 estudos retrospectivos de coorte, 2 ensaios clínicos, um estudo retrospectivo de controle de caso, um estudo de coorte prospectivo, um estudo de diagnóstico e um estudo clínico multicêntrico retrospectivo.

Para sistematizar os achados, foi elaborada uma tabela contendo as principais características de cada artigo: autor e ano de publicação, tipo de estudo, população estudada e objetivo (Quadro 1).

Quadro 1: Descrição dos estudos incluídos ( $\mathrm{n}=12)$

\begin{tabular}{|c|c|c|c|}
\hline Autor, ano. & Tipo de estudo & População estudada & Objetivo \\
\hline $\begin{array}{l}\text { Cai SH. et } \\
\text { al., } 2020\end{array}$ & $\begin{array}{l}\text { Estudo clínico } \\
\text { multicêntrico } \\
\text { retrospectivo. }\end{array}$ & $\begin{array}{l}96 \text { pacientes internados com } \\
\text { infecção pelo SARS-CoV-2 } \\
\text { foram matriculados no Hospital } \\
\text { Do Povo de Dongguan, no } \\
\text { hospital de Nanfang e no }\end{array}$ & $\begin{array}{l}\text { Investigar se a obesidade } \\
\text { desempenhou um papel nas } \\
\text { manifestações clínicas e } \\
\text { prognóstico em pacientes }\end{array}$ \\
\hline
\end{tabular}




\begin{tabular}{|c|c|c|c|}
\hline & & $\begin{array}{l}\text { Primeiro Hospital Afiliado da } \\
\text { Universidade de Xiamen. }\end{array}$ & $\begin{array}{l}\text { infectados com SARS-CoV- } \\
2 .\end{array}$ \\
\hline $\begin{array}{l}\text { Chiappetta } \\
\text { S. et al., } \\
2020\end{array}$ & $\begin{array}{l}\text { Estudo de } \\
\text { diagnóstico. }\end{array}$ & $\begin{array}{l}33 \text { pacientes com obesidade } \\
\text { metabólica (EOSS } 2 \text { e } 3 \text { ). }\end{array}$ & $\begin{array}{l}\text { Avaliar os fatores associados } \\
\text { à anemia em gestantes } \\
\text { atendidas pela rede pública } \\
\text { de saúde de uma capital do } \\
\text { Nordeste do Brasil. }\end{array}$ \\
\hline $\begin{array}{l}\text { Hamer M et } \\
\text { al., } 2020\end{array}$ & $\begin{array}{l}\text { Estudo de } \\
\text { coorte. }\end{array}$ & $\begin{array}{l}\text { Estudo populacional com dados } \\
\text { de uma amostra de moradia } \\
\text { comunitária na Inglaterra }(\mathrm{n}= \\
334.329 ; 56,4 \pm 8,1 \text { y; } 54,5 \% \\
\text { mulheres) com potencial de } \\
\text { ligação ao registro nacional de } \\
\text { internação por COVID-19. }\end{array}$ & $\begin{array}{l}\text { Examinar associações entre } \\
\text { IMC, obesidade central e } \\
\text { COVID-19. }\end{array}$ \\
\hline $\begin{array}{l}\text { Kalligeros M. } \\
\text { et al., } 2020\end{array}$ & $\begin{array}{l}\text { Estudo de coorte } \\
\text { retrospectivo. }\end{array}$ & $\begin{array}{l}103 \text { pacientes internados com } \\
\text { COVID- } 19 .\end{array}$ & $\begin{array}{l}\text { Explorar a potencial } \\
\text { associação da obesidade e } \\
\text { outras doenças crônicas com } \\
\text { desfechos graves, como } \\
\text { internação em Unidade de } \\
\text { Terapia Intensiva (UTI) e } \\
\text { Ventilação Mecânica } \\
\text { Invasiva (IMV), em pacientes } \\
\text { internados com COVID-19. }\end{array}$ \\
\hline $\begin{array}{l}\text { Lemyze M. } \\
\text { et al., } 2020\end{array}$ & $\begin{array}{l}\text { Estudo } \\
\text { retrospectivo de } \\
\text { controle de } \\
\text { caso. }\end{array}$ & $\begin{array}{l}44 \text { pacientes com síndrome de } \\
\text { câncer respiratório agudo } 2019 \\
\text { foram comparados com um } \\
\text { grupo histórico de } 39 \text { pacientes } \\
\text { consecutivos com síndrome de } \\
\text { desconforto respiratório agudo } \\
\text { admitidos na UTI pouco antes } \\
\text { da crise da doença coronavírus } \\
2019 \text {. }\end{array}$ & $\begin{array}{l}\text { Investigar as características, } \\
\text { o manejo e os desfechos da } \\
\text { população gravemente } \\
\text { doente admitido na UTI para } \\
\text { a doença coronavírus de } \\
\text { síndrome respiratória aguda } \\
\text { grave } 2019 \text { causando uma } \\
\text { síndrome de angústia } \\
\text { respiratória aguda. }\end{array}$ \\
\hline $\begin{array}{l}\text { Memtsoudis } \\
\text { SG. et al., } \\
2020\end{array}$ & $\begin{array}{l}\text { Ensaio clínico } \\
\text { controlado. }\end{array}$ & $\begin{array}{l}\text { Dados de } 113 \text { pacientes com } \\
\text { COVID-19 em três UTIs dos } \\
\text { EUA. }\end{array}$ & $\begin{array}{l}\text { Avaliar a prevalência do uso } \\
\text { de suplementação com ácido } \\
\text { fólico em gestantes e } \\
\text { identificar fatores associados } \\
\text { à não realização dessa } \\
\text { prática. }\end{array}$ \\
\hline $\begin{array}{l}\text { Mostaghim } \\
\text { A. et al., } \\
2020\end{array}$ & $\begin{array}{l}\text { Estudo } \\
\text { retrospectivo de } \\
\text { coorte. }\end{array}$ & $\begin{array}{l}791 \text { pacientes com idade } \geq 18 \\
\text { anos internados com teste } \\
\text { positivo de PCR SARS-CoV- } 2 \text {. }\end{array}$ & $\begin{array}{l}\text { Caracterizar a associação } \\
\text { entre desfechos clínicos em } \\
\text { pacientes com obesidade e } \\
\text { marcadores inflamatórios. }\end{array}$ \\
\hline $\begin{array}{l}\text { Nakeshbandi } \\
\text { M. et al., } \\
2020\end{array}$ & $\begin{array}{l}\text { Estudo } \\
\text { retrospectivo de } \\
\text { coorte. }\end{array}$ & 684 pacientes com COVID-19. & $\begin{array}{l}\text { Elucidar a associação entre } \\
\text { obesidade e desfechos } \\
\text { COVID-19. }\end{array}$ \\
\hline
\end{tabular}




\begin{tabular}{|c|c|c|c|}
\hline $\begin{array}{l}\text { Peters SAE. } \\
\text { et al., } 2020\end{array}$ & $\begin{array}{l}\text { Estudo de coorte } \\
\text { prospectivo. }\end{array}$ & $\begin{array}{l}\text { Análise de dados retirados do } \\
\text { UK do Reino Unido. }\end{array}$ & $\begin{array}{l}\text { Avaliar o risco de } \\
\text { mortalidade por COVID-19 } \\
\text { associada a várias medidas } \\
\text { antropométricas em } \\
\text { mulheres e homens. }\end{array}$ \\
\hline $\begin{array}{l}\text { Simonnet A. } \\
\text { et al., } 2020\end{array}$ & $\begin{array}{l}\text { Estudo } \\
\text { retrospectivo. }\end{array}$ & $\begin{array}{l}124 \text { pacientes consecutivos } \\
\text { internados em tratamento } \\
\text { intensivo para SARS-CoV-2 em } \\
\text { um único centro francês. }\end{array}$ & $\begin{array}{l}\text { Investigar a relação entre } \\
\text { obesidade e síndrome } \\
\text { respiratória aguda grave } \\
\text { coronavírus-2 (SARS-CoV- } \\
\text { 2). }\end{array}$ \\
\hline $\begin{array}{l}\text { Singh S. et } \\
\text { al., } 2020\end{array}$ & $\begin{array}{l}\text { Estudo } \\
\text { retrospectivo de } \\
\text { coorte. }\end{array}$ & $\begin{array}{l}\text { Dados de prontuários } \\
\text { eletrônicos de } 41.513 \text { pacientes } \\
\text { adultos ( } \geq 18 \text { anos), } \\
\text { diagnosticados com COVID-19, } \\
\text { de } 26 \text { organizações de saúde } \\
\text { nos Estados Unidos. através da } \\
\text { plataforma TriNetX. }\end{array}$ & $\begin{array}{l}\text { Avaliar os impactos da } \\
\text { obesidade nos desfechos de } \\
\text { pacientes internados com } \\
\text { COVID-19. }\end{array}$ \\
\hline $\begin{array}{l}\text { Steinberg E } \\
\text { et al., } 2020\end{array}$ & $\begin{array}{l}\text { Estudo de coorte } \\
\text { retrospectivo. }\end{array}$ & 210 pacientes com COVID-19. & $\begin{array}{l}\text { Identificar se os desfechos } \\
\text { adversos estão associados à } \\
\text { obesidade, particularmente } \\
\text { em pacientes COVID-19 com } \\
45 \text { anos ou mais. }\end{array}$ \\
\hline
\end{tabular}

Fonte: Os autores

Cai e colaboradores (2020), ao investigarem se a obesidade poderia desenvolver algum papel nas manifestações clínicas e no prognóstico dos pacientes infectados com SARS-CoV-2, encontraram que o índice de massa corporal (IMC) estava significativamente relacionado com manifestações clínicas e resultados clínicos dos pacientes infectados por COVID-19.

Rocha e colaboradores corroboram enfatizando que existe associação entre obesidade e um pior prognóstico dos pacientes com infecção por SARS-Cov-2, deixando evidente que pacientes com sobrepeso e obesidade apresentam um maior risco de desenvolverem sintomas severos da doença, além de precisarem ser hospitalizados com maior frequência. Ademais, constatou-se que esses indivíduos tiveram uma maior admissão em unidades intensivas de cuidado (UTI) e na maioria dos casos, necessitaram de assistência respiratória assistida, além de verificar uma 
maior mortalidade por COVID-19 associada à obesidade.

Já Chiapeta e colaboradores (2020) alertam através de seus estudos que os médicos devem estar cientes de que a obesidade sendo classificada com base na estratificação de risco através do Sistema de Estadiamento da Obesidade de Edmonton (EOSS) que utiliza classificações médicas, mentais e/ou funcionais de pacientes, e não apenas com base no IMC, demonstrou melhor preditor da mortalidade por todas as causas e pode muito bem ser que os estágios da EOSS possam descrever melhor o risco de hiperinflamação em pacientes com infecção por COVID-19. Sendo que, a identificação precoce de uma possível grande inflamação possui papel fundamental na tomada de decisão em situações de hospitalização, suporte respiratório precoce e terapia com imunossupressão para melhora dos casos. Por esse mesmo lado, Hamer e colaboradores (2020) notaram uma maior probabilidade de COVID-19 e hospitalização em indíviduos com aumento da adiposidade geral e central, entrando em acordo com achados já citados.

Segundo Chait \& Hartigh (2020) a distribuição do tecido adiposo exibe grande importância nos indicadores de saúde, pois a gordura subcutânea vastamente expandida em indivíduos saudáveis, localizada na parte superior ou inferior da pele, é considerada com menor risco para o desenvolvimento de doenças crônicas, porém, quando essa reserva se acumula na parte visceral, contribui para a resistência à insulina, dislipidemia, aterosclerose, inflamação, diabetes II, síndrome metabólica e maior risco de doença cardiovascular (DCV).

Kalligeros e colaboradores (2020) observaram que a obesidade grave (IMC $\geq$ $35 \mathrm{~kg}$ / m2) esteve associada à admissão na UTI da amostra pesquisada, e sugerem, ainda, a necessidade de maior vigilância e tratamento ativo de pacientes com obesidade e COVID-19. Nesse mesmo contexto, Mostaghim e colaboradores (2020), ao estudarem uma amostra com o objetivo de caracterizar a associação entre desfechos clínicos em pacientes com obesidade e marcadores inflamatórios, encontratam que, de 791 pacientes com Covid-19, 361 (45,6\%) tinham obesidade. Nas análises multivariadas realizadas, o alto grau de IMC manteve-se associado a uma maior chance de transferência para a UTI, além de mortalidade hospitalar, concluindo, assim, que pacientes com obesidade estariam mais propensos a ter maus resultados.

Lemyze e colaborades (2020) alegam que, em sua forma mais grave, a doença 
coronavírus 2019 atingiu, preferencialmente, a população obesa vulnerável, evoluindo para uma falência múltipla dos órgãos, ordenando apoio ventilatório mecânico delongado. Além disso, exigiu maior atenção e trabalho dos cuidadores. Concordando com Stavros e colaborades (2020) que, através de evidências preliminares, sugerem que a COVID-19 pode acarretar maiores prejuizos à saúde de idosos. Além disso, grande variedade de comorbidades é prevalente, a maioria notavelmente hipertensão, diabetes mellitus e doenças cardiovasculares, incluindo a obesidade.

Enfatizando sobre tais achados, Steinberg e colaboradores (2020), em um estudo de coorte retrospectivo, com 210 pacientes com COVID-19, notaram que todos os desfechos encontrados estiveram associados ao IMC elevado, concluindo que a obesidade esteve relacionada aos maus resultados em pacientes hospitalizados com essa doença.

Nakeshbandi e colaboradores (2020) apontam que o sobrepeso e a obesidade em pacientes acometidos com COVID-19 apresentaram risco aumentado de mortalidade e intubação quando comparados com aqueles que possuem IMC adequado.

Peters Sae e colaboradores (2020) observaram que o IMC esteve relacionado a um maior risco de mortalidade por COVID-19 em mulheres do que em homens, a razão de risco de mulheres para homens foi de 1,20 (intervalo de confiança de 95\% $1,00 ; 1,43)$. O estudo demonstrou o papel da obesidade na mortalidade de COVID-19 e mostra que os efeitos de um IMC elevado na mortalidade de COVID-19 podem ser mais fortes em mulheres do que homens. Por outro lado, os achados de Qingxian e colaboradores (2020) evidenciaram uma prevalência 42 vezes maior para o desenvolvimento de pneumonia grave comparando com aqueles em estado eutrófico, sendo o público masculino 4,4 vezes maior de progressão para a gravidade em relação ao feminino. De todo modo, chama-se a atenção para a obesidade manter-se associada a maiores complicações em diferentes estudos, em ambos os sexos.

Simonnet e colaboradores (2020) identificaram uma alta prevalência de pacientes obesos internados em terapia intensiva por SARS-CoV-2, sendo que, a gravidade da doença esteve aumentada de acordo com o IMC, concluindo que a obesidade é um fator de risco para o agravo da SARS-CoV-2, exigindo maior atenção às medidas preventivas nesses indivíduos.

Singh e colaboradores (2020) em seus estudos observaram que os pacientes 
com COVID-19, acometidos com qualquer grau de obesidade, tiveram um risco significativamente maior de internação e intubação ou morte em comparação com os pacientes sem obesidade. Os pacientes com obesidade severa apresentavam riscos ainda maiores de resultados ruins.

\section{CONSIDERAÇÕES FINAIS}

É percebido que a pandemia em decorrência dos quadros de obesidade é uma situação que pode ser controlada e reversível, uma vez que envolve, primordialmente, a adoção de mudanças no comportamento alimentar humano. No entanto, vale salientar, que por envolver questões socioculturais, e também emocionais e psicológicos, é preciso ter uma abordagem além de apenas controlar e orientar sobre questões alimentares exclusivamente.

Tendo visto que um dos fatores que mais pode influenciar, de maneira negativa, no prognóstico de pacientes portadores de obesidade, e que foram infectados pelo SARS-CoV-2, seja o quadro inflamado do paciente obeso, o presente estudo permite concluir que indíviduos portadores de obesidade possuem maiores chances de apresentarem complicações quando testados positivos para COVID-19, sendo que, estes, estão mais propensos a desenvolverem complicações durante o período de internação.

A literatura evidencia, de forma bem elucidada, o quanto é necessário a intensificação das orientações e acompanhamento de profissionais de saúde, com equipe multidisciplinar, no intuito de evitar a progressão e reduzir os resultados graves da COVID-19. Além disso, é preciso que sejam evidenciadas medidas pautadas no estilo de vida saudável para a melhora do estado nutricional.

Por fim, com base nos achados desse estudo, se faz pertinente a realização de estudos futuros a respeito do tema, a fim de possibilitar um melhor tratamento para pacientes enquadrados nesse cenário, e ainda, pela necessidade de examinar as características clínicas e os fatores de risco de pacientes com COVID-19 em populações grandes e diversas. 


\section{REFERÊNCIAS}

Abbas, A. M., Fathy, S. K., Fawzy, A. T., Salem, A. S., \& Shawky, M. S. (2020). Os efeitos mútuos de COVID-19 e obesidade. Remédio para obesidade, 19, 100250. https://doi.org/10.1016/j.obmed.2020.100250

Cai SH, Liao W, Chen SW, Liu LL, Liu SY, Zheng ZD. Associação entre obesidade e prognóstico clínico em pacientes infectados com SARS-CoV-2. Infectar a Pobreza. 2020 Jun 29;9(1):80. doi: 10.1186/s40249-020-00703-5. PMID: 32600411; PMCID: PMC7322704.

Carneiro, A. B.; Dall'Igna, D. M. Obesidade como fator de risco para o agravamento da Covid-19: uma breve revisão de literatura. Vittalle - Revista de Ciências da Saúde v. 32, n. 3, p. 12-18, 2020.

Chait, A., den Hartigh, L. J. Adipose Tissue Distribution, Inflammation and Its Metabolic Consequences, Including Diabetes and Cardiovascular Disease. Front Cardiovasc Med. 7, 22. Published 2020 Feb 25. doi:10.3389/fcvm.2020.00022

Chiappetta, S., Sharma, A.M., Bottino, V. et al. COVID-19 e o papel da inflamação crônica em pacientes com obesidade. Int J Obes 44, 1790-1792 (2020). https://doi.org/10.1038/s41366-020-0597-4

Cummings, M. J., Baldwin, M. R., Abrams, D., Jacobson, S. D., Meyer, B. J., Balough, E. M., \& Hochman, B. R. (2020). Epidemiology, clinical course, and outcomes of critically ill adults with COVID-19 in New York City: a prospective cohort study. The Lancet. https://doi.org/10.1016/S0140-6736(20)31189-2

Dias PC, Henriques P, Anjos LA, Burlandy L. Obesidade e políticas públicas: concepções e estratégias adotadas pelo governo brasileiro. Cadernos de Saúde Pública 2017; 33(7): e00006016.

Hamer M, Gale CR, Kivimäki M, Batty GD. Overweight, obesity, and risk of hospitalization for COVID-19: A community-based cohort study of adults in the United 331Kingdom. Proc Natl Acad Sci U S A. 2020.

Kalligeros M, Shehadeh F, Mylona EK, Benitez G, Beckwith CG, Chan PA, Mylonakis E. Association of Obesity with Disease Severity Among Patients with Coronavirus Disease 2019. Obesidade (Primavera da Prata). 2020 Jul;28(7):1200-1204. doi: 10.1002/oby.22859. Epub 2020 Jun 12. 32352637; PMCID: PMC7267224.

Lemyze M, Courageux N, Maladobry T, Arumadura C, Pauquet P, Orfi A, Komorowski M, Mallat J, Granier M. Implications of Obesity for the Management of Severe Coronavirus Disease 2019 Pneumonia. Crit Care Med. 2020 Set;48(9):e761e767. doi: 10.1097/CCM.000000000000455. PMID: 32452889; PMCID: PMC7255399.

Melo, S. P. S. C.; Cesse, E. A. P.; Lira, P. I. C.; Ferreira, L. C. C. N.; Rissin, A.; Batista Filho, M. Sobrepeso, obesidade e fatores associados aos adultos em uma 
área urbana carente do Nordeste Brasileiro. Rev. Bras. Epidemiol., v. 23, p. 1-14, 2020. doi: 10.1590/1980-549720200036

Memtsoudis SG, Ivascu NS, Pryor KO, Goldstein PA. Obesidade como fator de risco para o mau resultado na lesão pulmonar induzida pelo COVID-19: o papel potencial da apneia obstrutiva obstrutiva do sono não diagnosticada. $\mathrm{Br} \mathrm{J}$ Anaesth. 2020;125(2):e262-e263. doi:10.1016/j.bja.2020.04.078

Mostaghim A, Sinha P, Bielick C, et al. Desfechos clínicos e níveis de marcadores inflamatórios em pacientes com Covid-19 e obesidade em um hospital de rede de segurança do centro da cidade. PLos Um. 2020;15(12):e0243888. Publicado em 2020 Dez 16. doi:10.1371/journal.pone.0243888

Nakeshbandi M, Maini R, Daniel P, Rosengarten S, Parmar P, Wilson C, Kim JM, Oommen A, Mecklenburg M, Salvani J, Joseph MA, Breitman I. O impacto da obesidade nas complicações do COVID-19: estudo retrospectivo de coorte. Int J Obes (Lond). 2020 Set;44(9):1832-1837. doi: 10.1038/s41366-020-0648-x. Epub 2020 Jul 25. PMID: 32712623; PMCID: PMC7382318.

Qingxian, C., Chen, F., Fang, L., Xiaohui, L., Tao, W., Qikai, W. Q., Zhaoqin, W., Liu, Y., a Jun, C., Lei, L., Lin, X., Obesity and COVID-19 Severity in a Designated Hospital in Shenzhen, China (3/13/2020). https://doi.org/.2139/ssrn.

Peters SAE, MacMahon S, Woodward M. Obesity as a risk factor for COVID-19 mortality in women and men in the UK biobank: Comparisons with influenza/pneumonia and coronary heart disease. Diabetes Obes Metab. 2021 Jan;23(1):258-262. doi: 10.1111/dom.14199. Epub 2020 Oct 11. PMID: 32969132; PMCID: PMC7536945.

Rocha GV, Soares CEM, Filho LOH, Amaral MVF, Castro VE, Júnior EA, Ribeiro KA, Amâncio NFG. A influência da obesidade na mortalidade de adultos com COVID-19. Brazilian Journal of Health Review, Curitiba, v.4, n.1, p.1405-1418 Jan/Feb. 2021 SBP-Sociedade Brasileira de Pediatria Departamento de Nutrologia Obesidade na infância e adolescência: Manual de Orientação. São Paulo: SBP; 2019.

Simonnet A, Chetboun M, Poissy J, Raverdy V, Noulette J, Duhamel A, Labreuche J, Mathieu D, Pattou F, Jourdain M; LICORN e o grupo de estudo Lille COVID-19 e Obesity. Alta prevalência de obesidade em Síndrome Respiratória Aguda Grave Coronavirus-2 (SARS-CoV-2) necessitando de ventilação mecânica invasiva. Obesidade (Primavera da Prata). 2020 Jul;28(7):1195-1199. doi: 10.1002/oby.22831. Epub 2020 Jun 10. Errata em: Obesidade (Primavera de Prata). 2020 Out;28(10):1994. PMID: 32271993; PMCID: PMC7262326.

Singh S, Bilal M, Pakhchanian H, Raiker R, Kochhar GS, Thompson CC. Impact of Obesity on Outcomes of Patients With Coronavirus Disease 2019 in the United States: A Multicenter Electronic Health Records Network Study. Gastroenterologia. 2020;159(6):2221-2225.e6. doi:10.1053/j.gastro.2020.08.028 
Steinberg E, Wright E, Kushner B. Em Adultos Jovens com COVID-19, a obesidade está associada a desfechos adversos. West J Emerg Med. v. 21, n. 4, p. 752-755, 2020. doi:10.5811/westjem.2020.5.47972

World Health Organization. Body mass index classification - report of a WHO consultation on obesity. Geneva: WHO; 1995. 


\section{SOBRE A ORGANIZADORA}

Dariane Cristina Catapan - Possui Doutorado em Ciência Animal pela Pontifícia Universidade Católica do Paraná (PUCPR), mestrado em Ciência Animal pela Pontifícia Universidade Católica do Paraná (PUCPR), especialização em Gestão Ambiental e Desenvolvimento Sustentável pela Faculdade de Tecnologia Internacional (FATEC), graduação em Medicina Veterinária pela Pontifícia Universidade Católica do Paraná (PUCPR) e Bacharelado em Administração pela Universidade Paulista (UNIP). Foi professora e coordenadora de curso na Faculdade da Indústria. Atualmente é Avaliadora do Sistema Nacional de Avaliação da Educação Superior (BASis) do Instituto Nacional de Estudos e Pesquisas Educacionais Anísio Teixeira (INEP/MEC), Brasil, e Editora-chefe da Brazilian Journal of Animal and Environment Research (BJAER) e Latin American Publicações Ltda. 
Agência Brasileira ISBN

ISBN: 978-65-992783-8-9 